\title{
Online supplement to "Identifying Global and National Output and Fiscal Policy Shocks Using a GVAR"
}

\author{
Alexander Chudik M. Hashem Pesaran Kamiar Mohaddes
}

December 2018

This online supplement is organized in two sections. Section S1 presents figures for the prior and posterior distributions of country-specific parameters $\alpha_{i}$ and $\beta_{i}$, for $i=1,2, \ldots, N$, and summary measures of posterior distribution of the effects of technology and fiscal policy shocks. Section S2 provides figures for the comparison of the effects of national technology and fiscal policy shocks in models with and without global shocks.

^Supplement DOI: https://doi.org/10.24149/gwp351supp 
S1 The prior and posterior distributions of parameters $\alpha$ and $\beta$, and summary measures of posterior distribution of the effects of technology and fiscal policy shocks

Figure S1: Posterior distributions of parameters $\alpha$ and $\beta$, and the effects of 1 percent technology and fiscal policy shocks for Argentina

Posterior distributions of parameters $\alpha$ and $\beta$
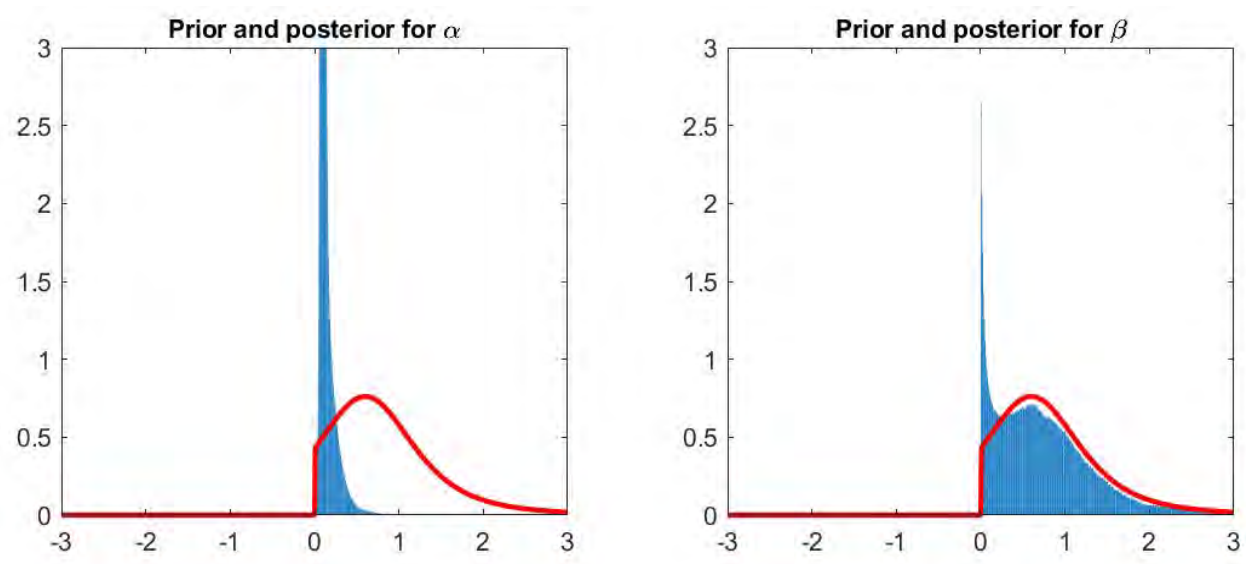

Posterior median (solid line) and 80 percent credible sets for the effects of 1 percent technology and fiscal policy shocks
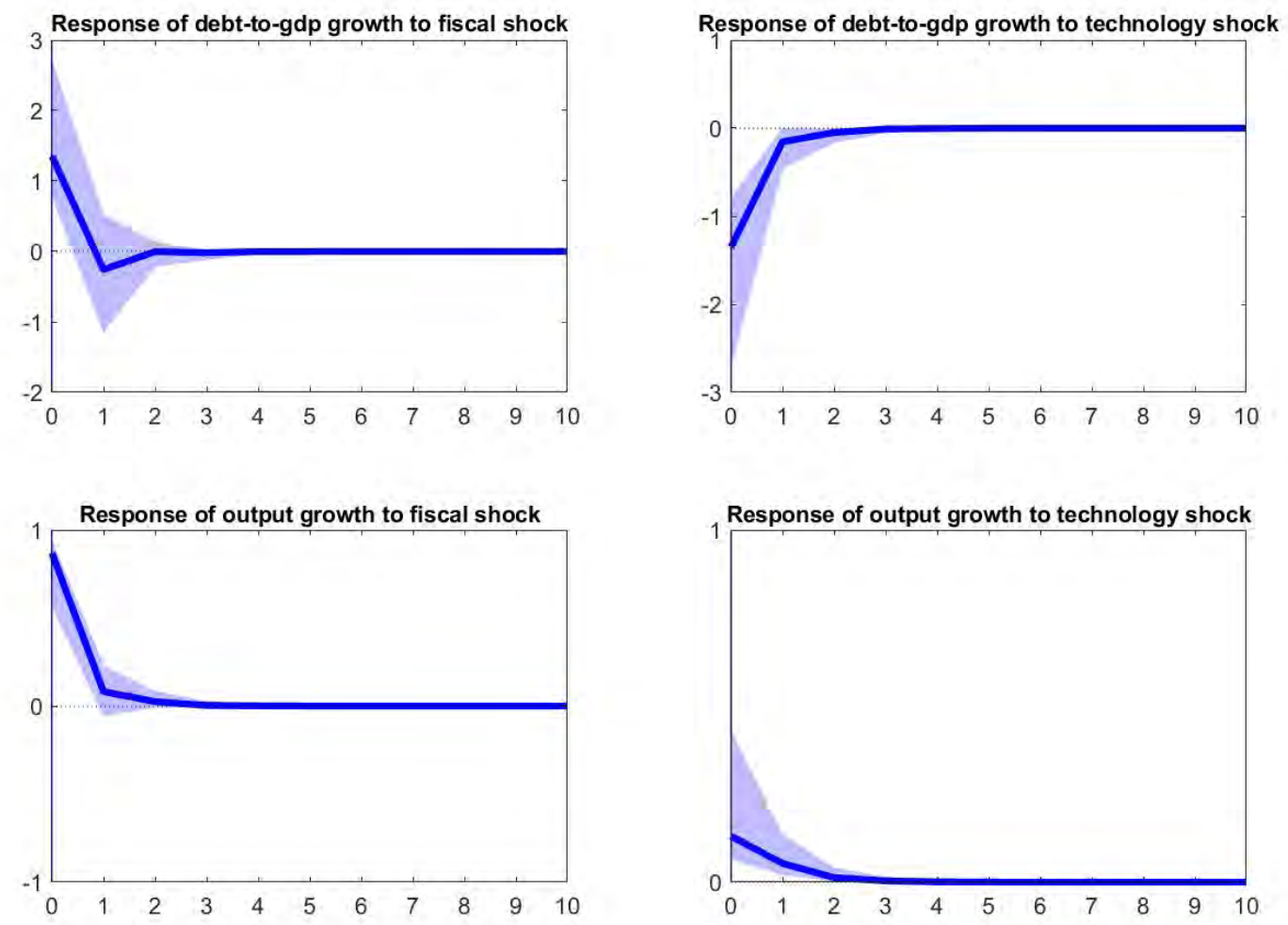
Figure S2: Posterior distributions of parameters $\alpha$ and $\beta$, and the effects of 1 percent technology and fiscal policy shocks for Australia

Posterior distributions of parameters $\alpha$ and $\beta$
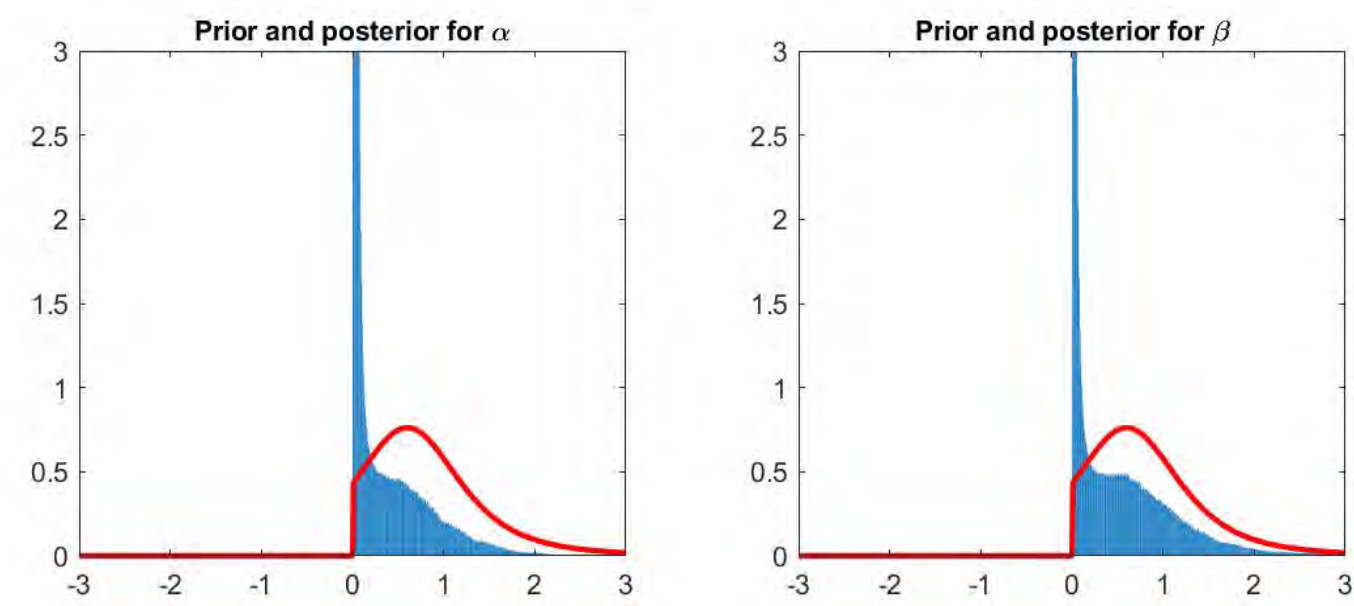

Posterior median (solid line) and 80 percent credible sets for the effects of 1 percent technology and fiscal policy shocks
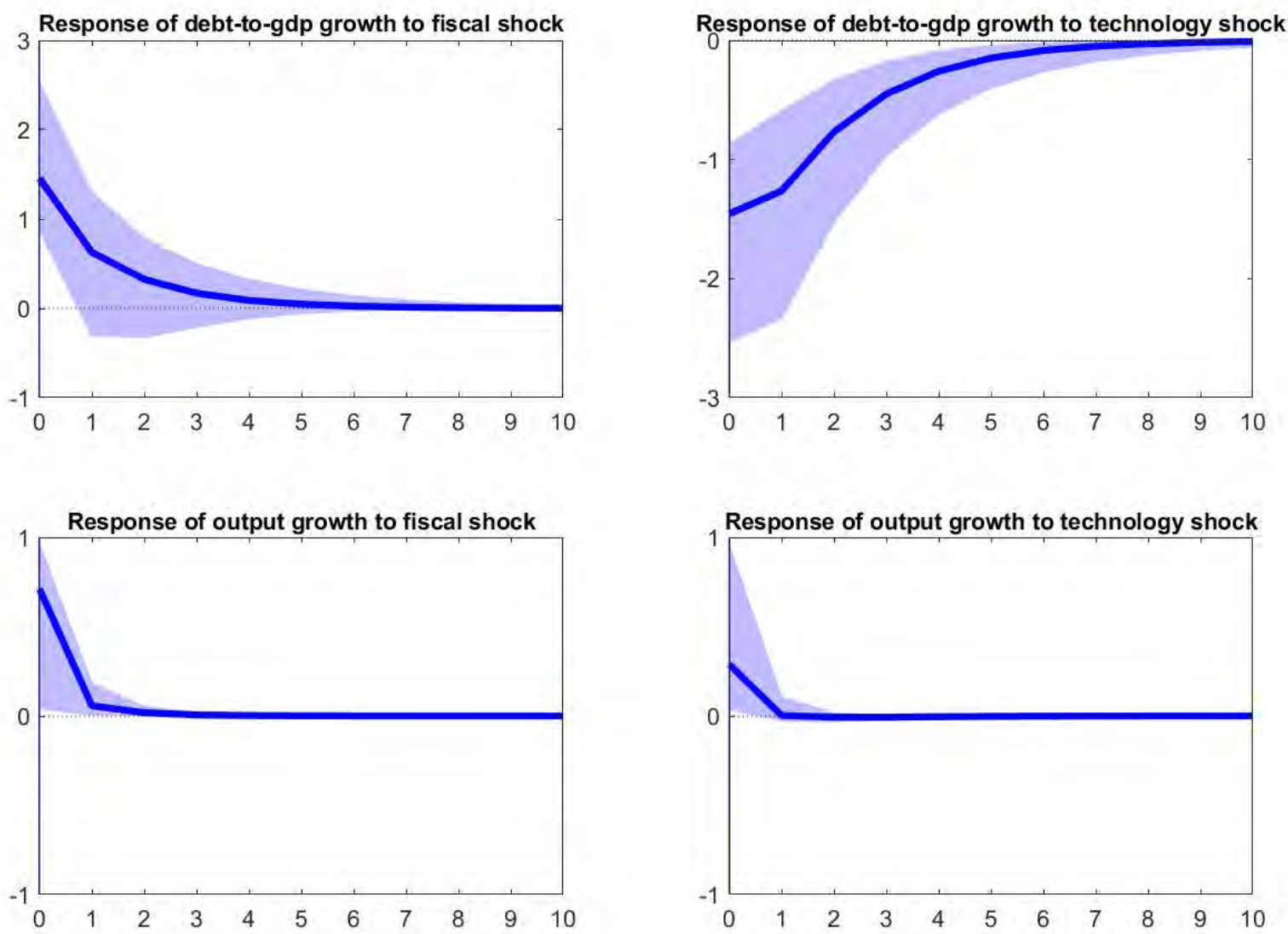
Figure S3: Posterior distributions of parameters $\alpha$ and $\beta$, and the effects of 1 percent technology and fiscal policy shocks for Austria

Posterior distributions of parameters $\alpha$ and $\beta$
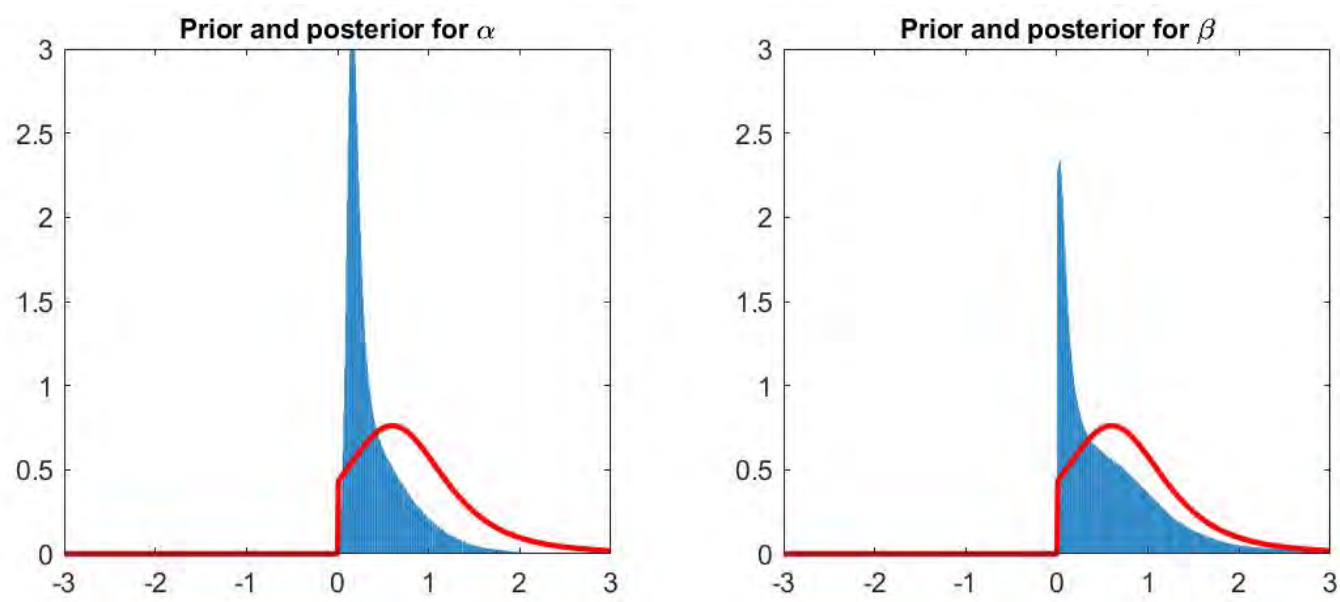

Posterior median (solid line) and 80 percent credible sets for the effects of 1 percent technology and fiscal policy shocks
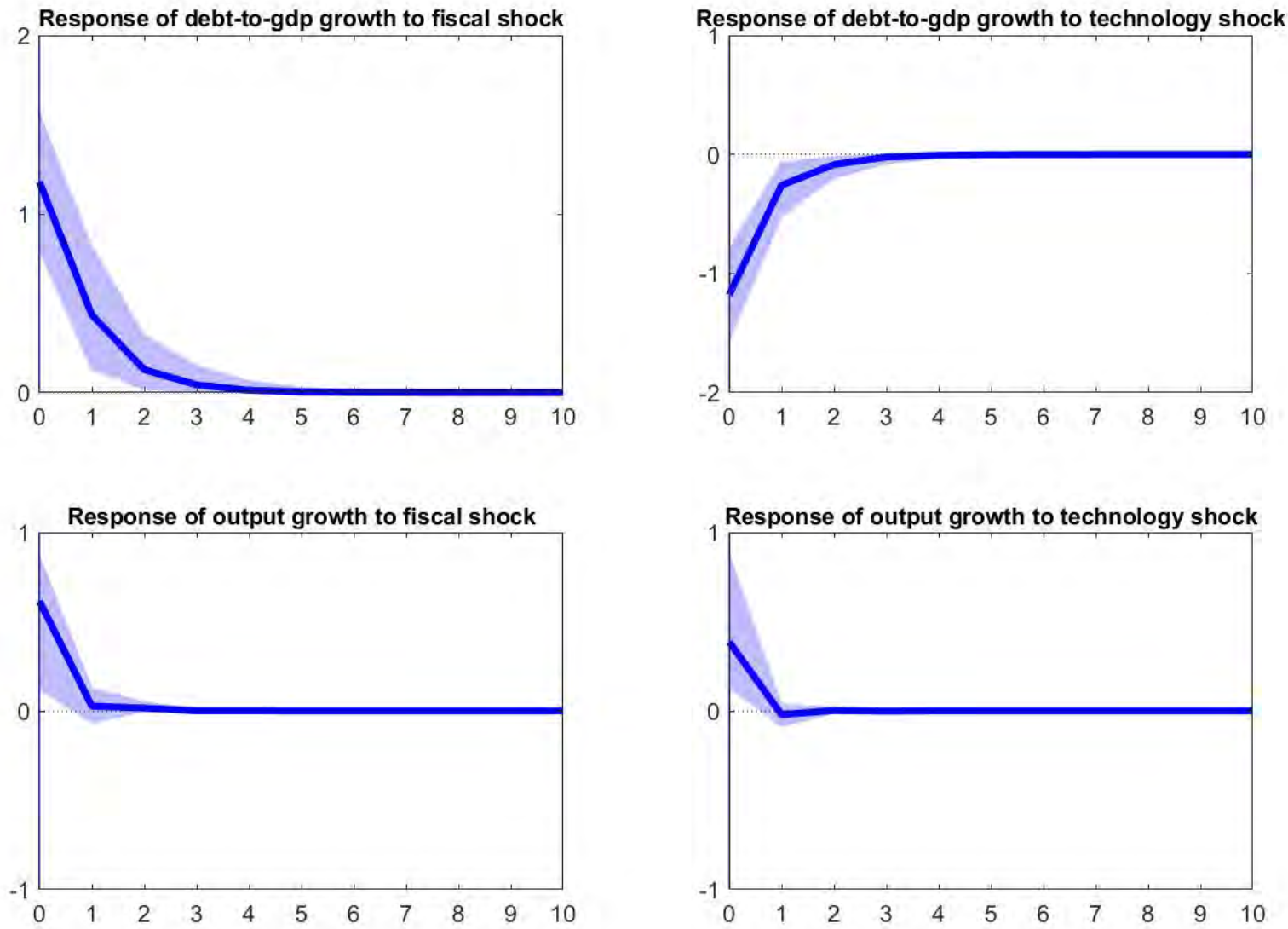
Figure S4: Posterior distributions of parameters $\alpha$ and $\beta$, and the effects of 1 percent technology and fiscal policy shocks for Belgium

Posterior distributions of parameters $\alpha$ and $\beta$
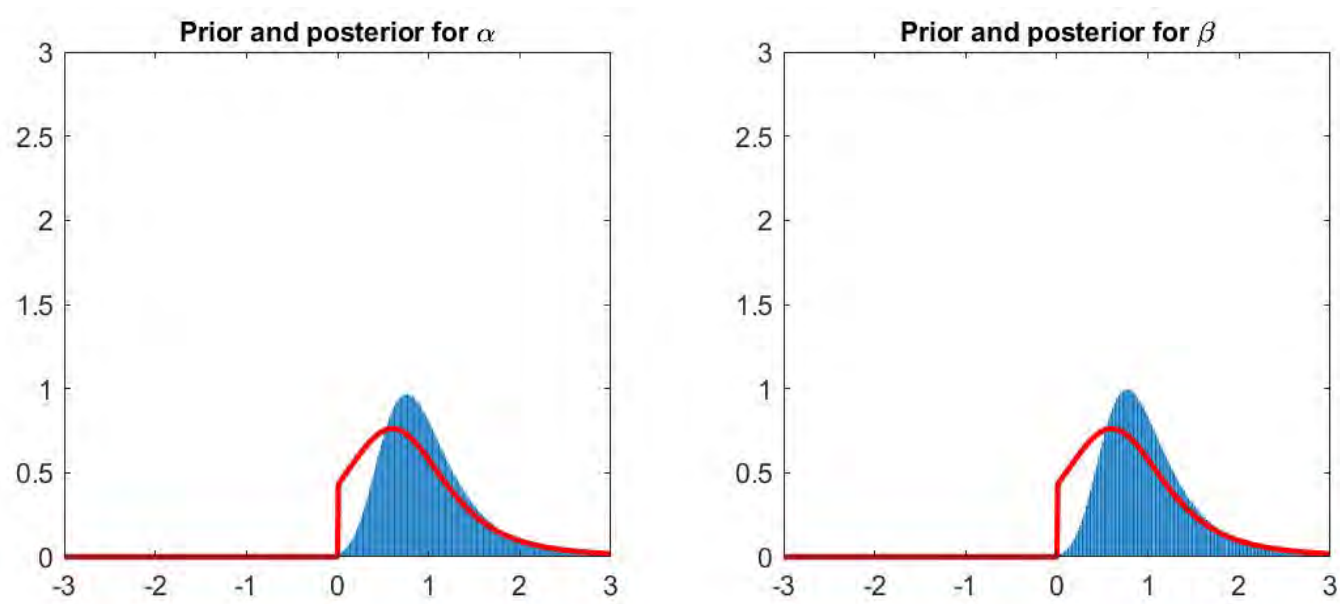

Posterior median (solid line) and 80 percent credible sets for the effects of 1 percent technology and fiscal policy shocks
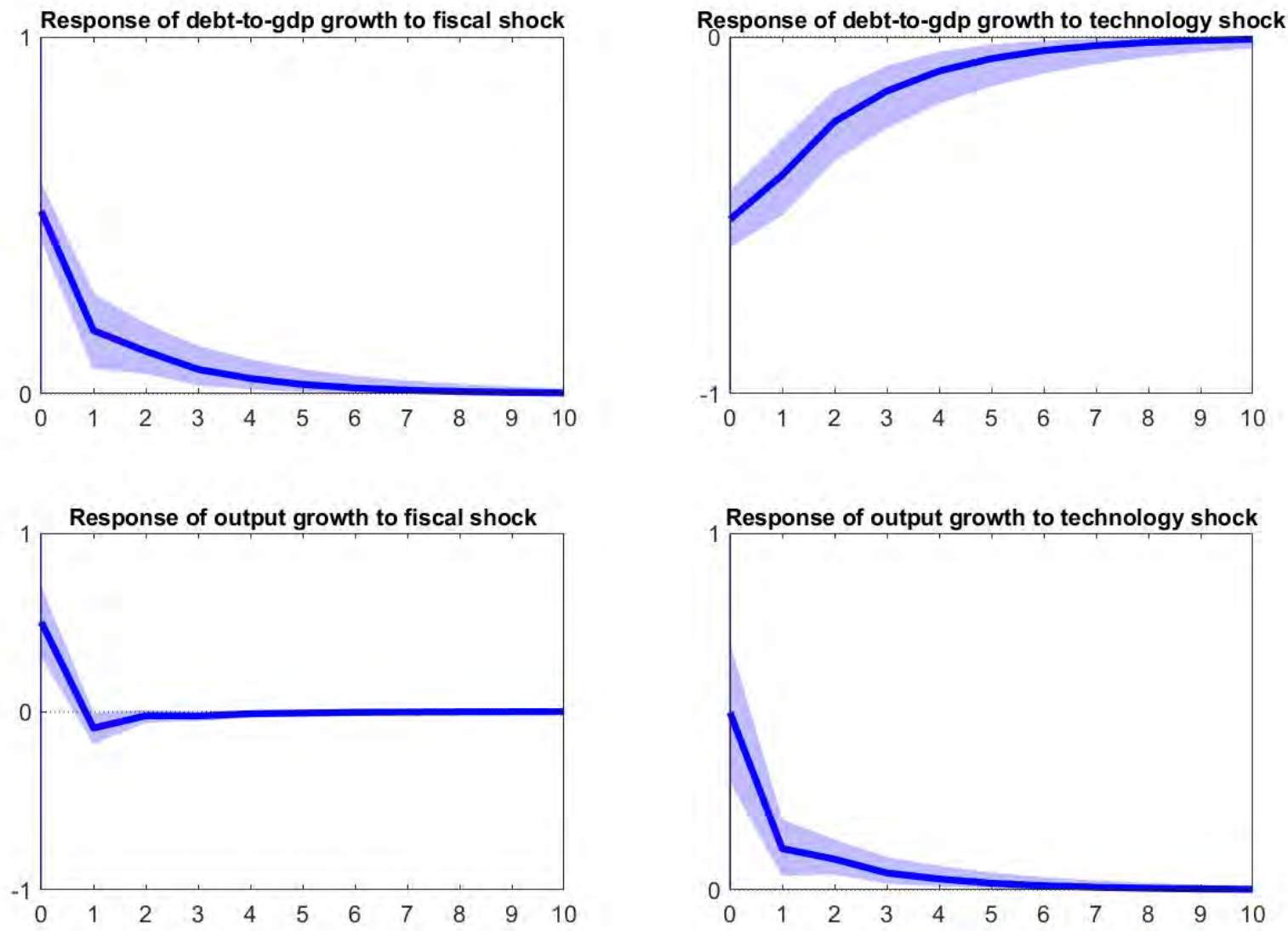
Figure S5: Posterior distributions of parameters $\alpha$ and $\beta$, and the effects of 1 percent technology and fiscal policy shocks for Brazil

Posterior distributions of parameters $\alpha$ and $\beta$
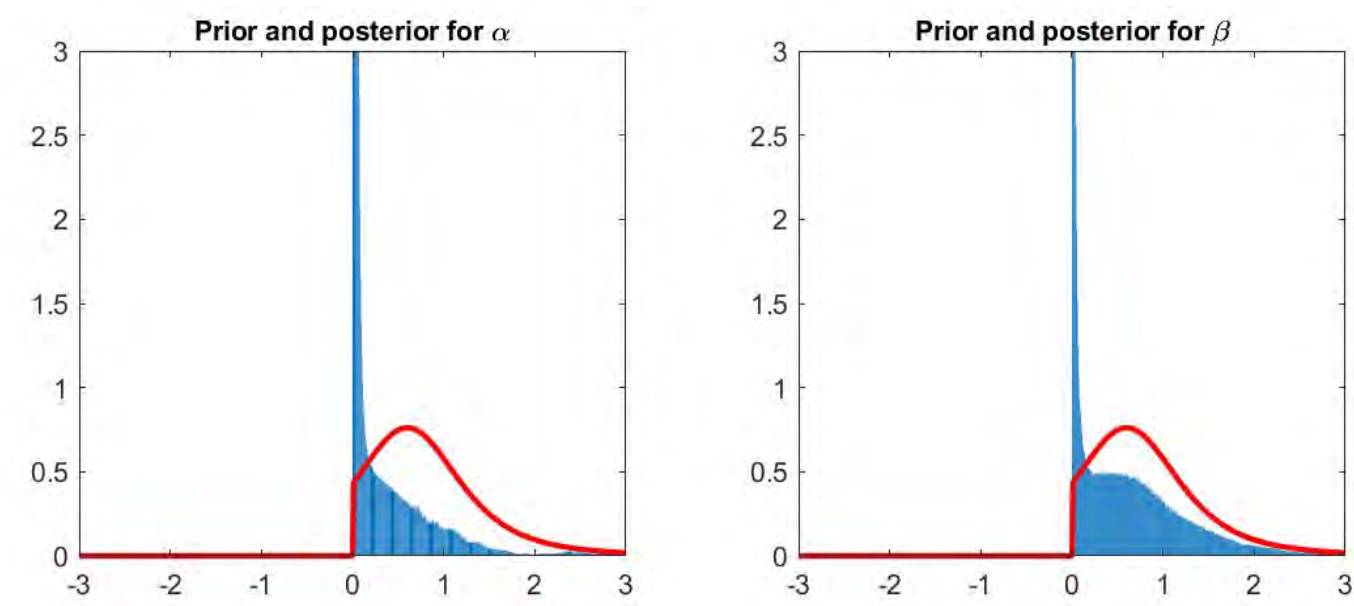

Posterior median (solid line) and 80 percent credible sets for the effects of 1 percent technology and fiscal policy shocks
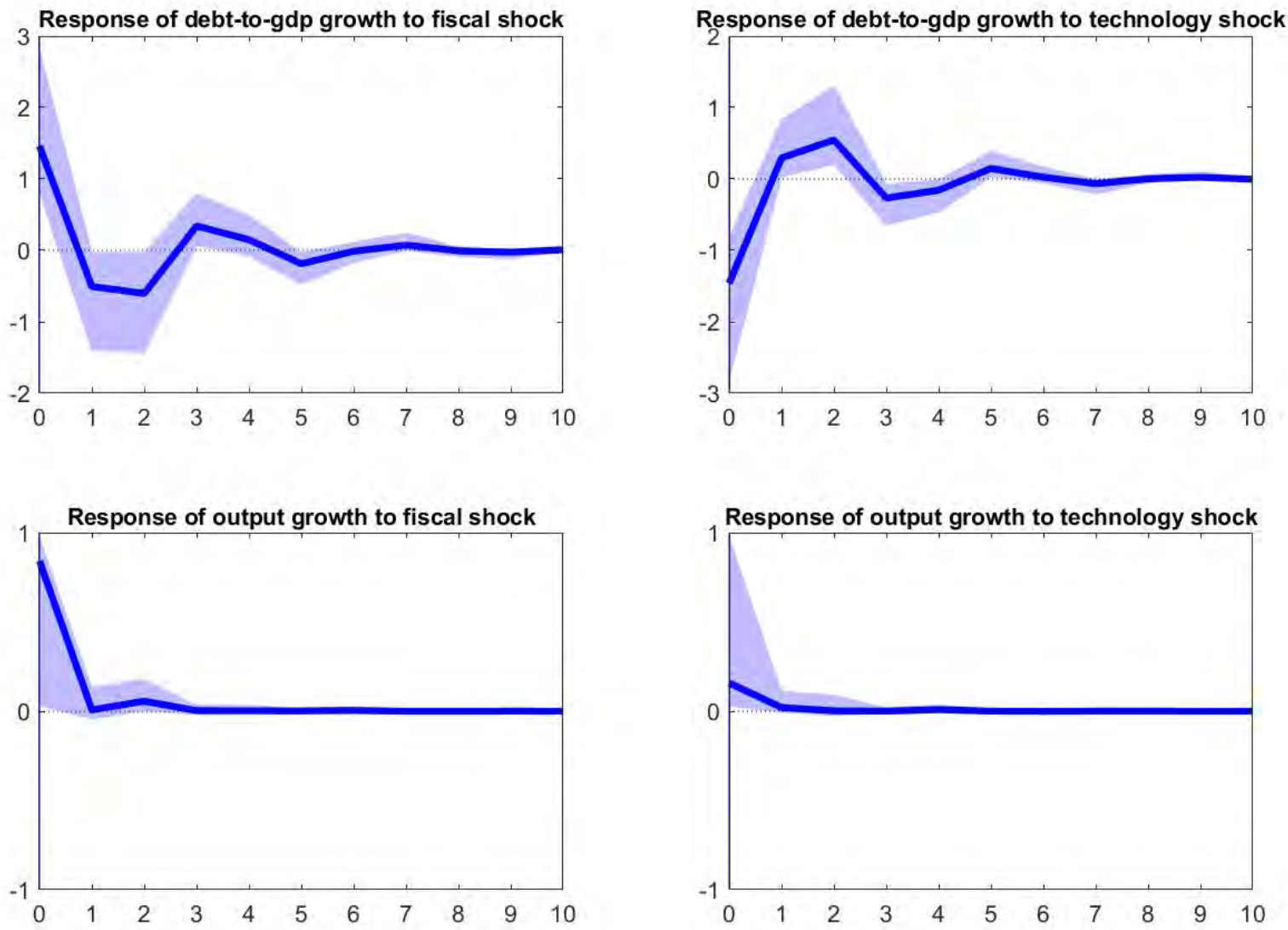
Figure S6: Posterior distributions of parameters $\alpha$ and $\beta$, and the effects of 1 percent technology and fiscal policy shocks for Canada

Posterior distributions of parameters $\alpha$ and $\beta$
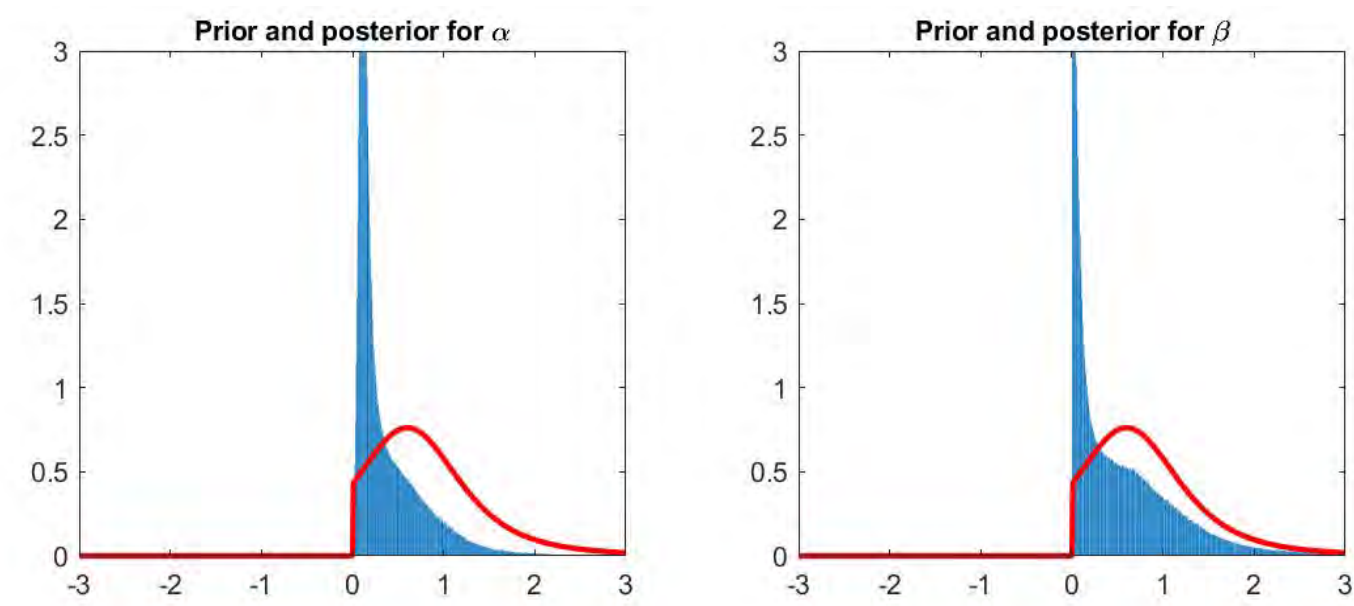

Posterior median (solid line) and 80 percent credible sets for the effects of 1 percent technology and fiscal policy shocks
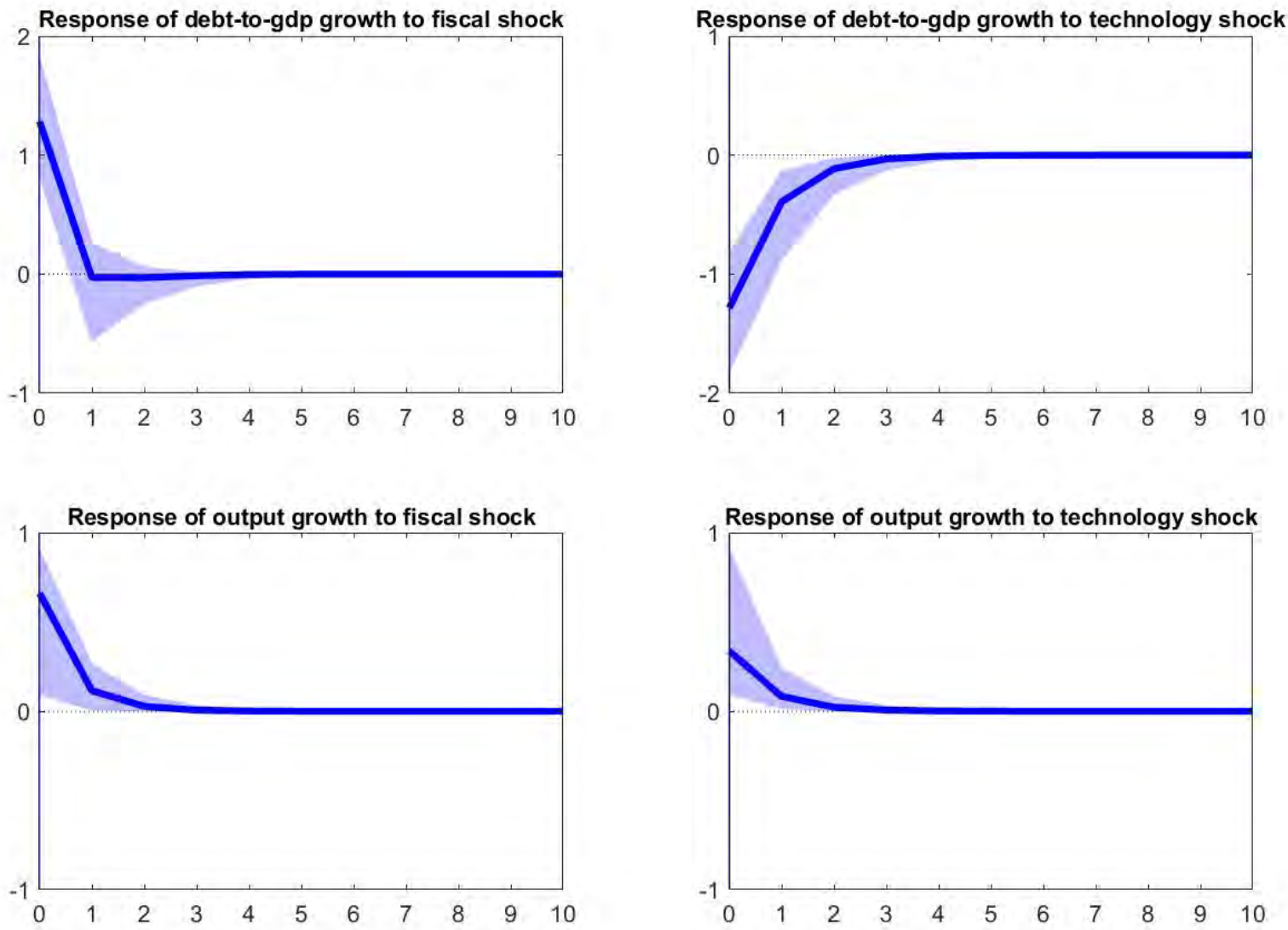
Figure S7: Posterior distributions of parameters $\alpha$ and $\beta$, and the effects of 1 percent technology and fiscal policy shocks for Chile

Posterior distributions of parameters $\alpha$ and $\beta$
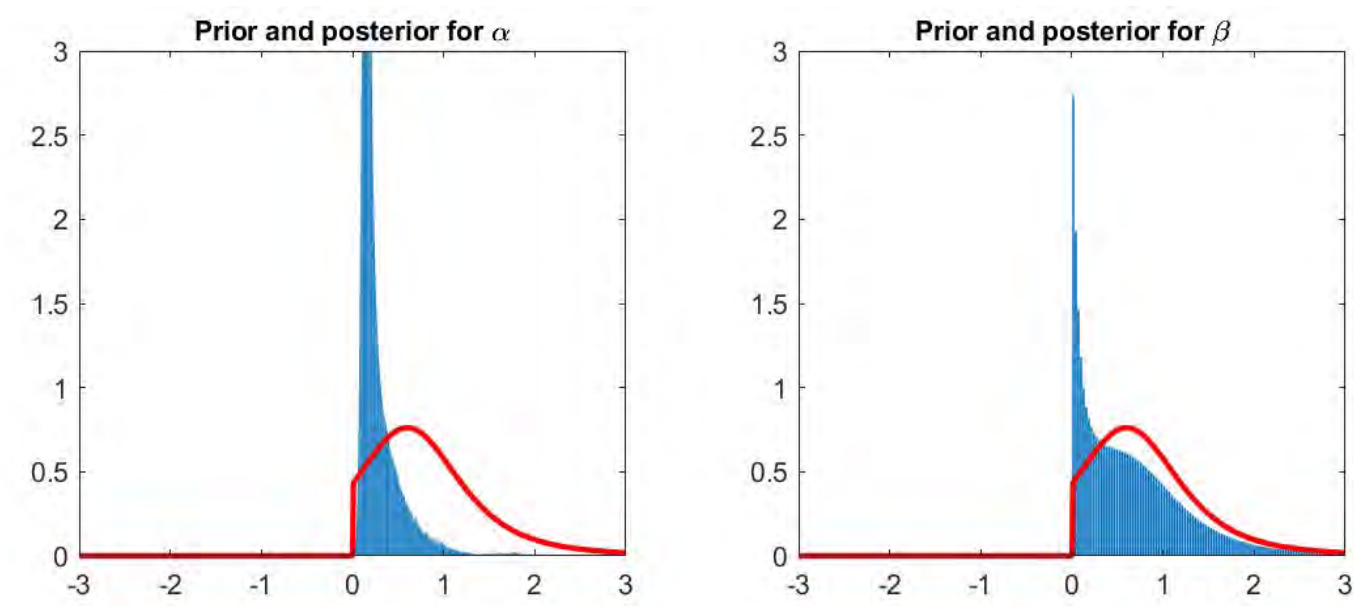

Posterior median (solid line) and 80 percent credible sets for the effects of 1 percent technology and fiscal policy shocks
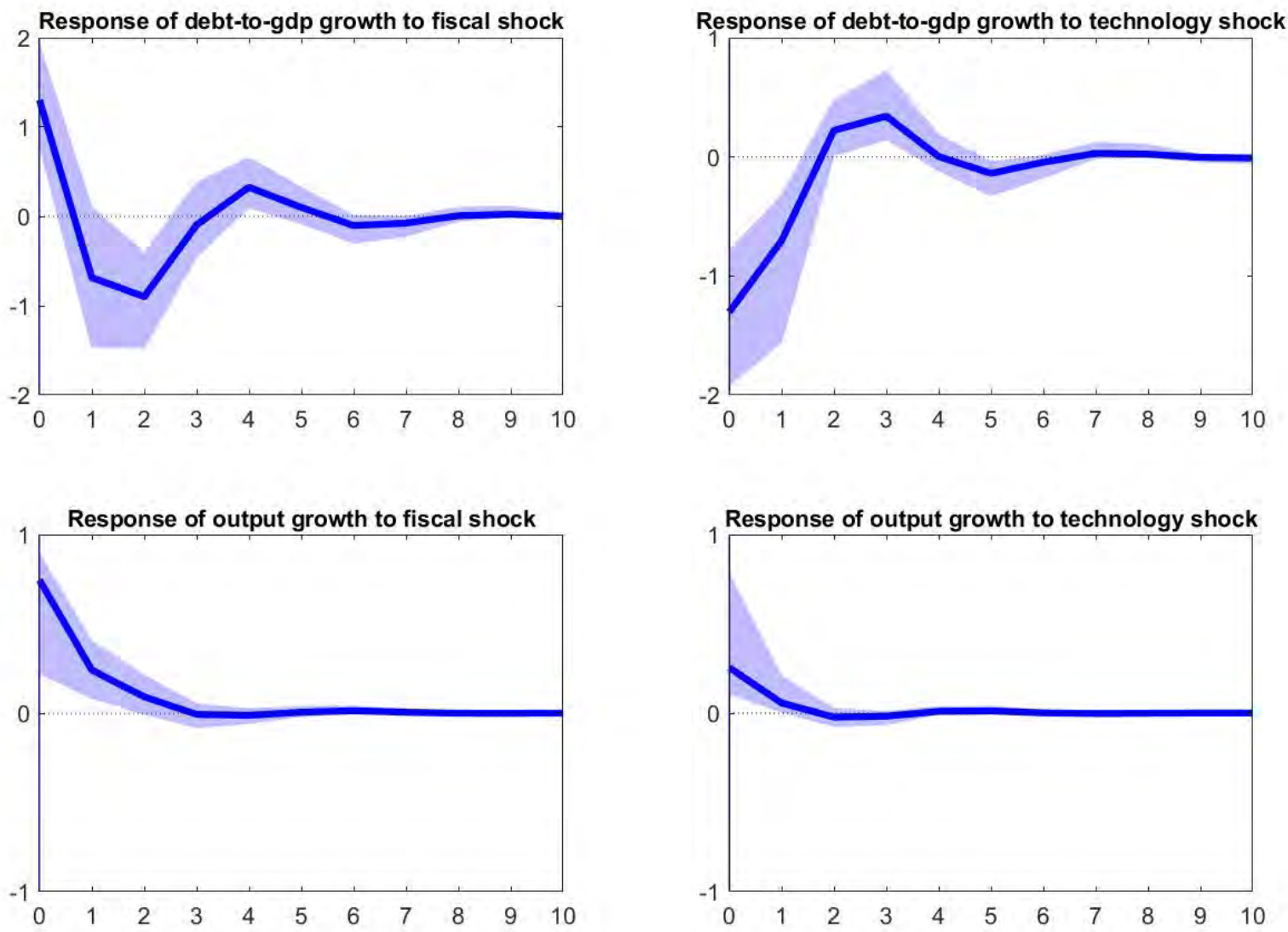
Figure S8: Posterior distributions of parameters $\alpha$ and $\beta$, and the effects of 1 percent technology and fiscal policy shocks for China

Posterior distributions of parameters $\alpha$ and $\beta$
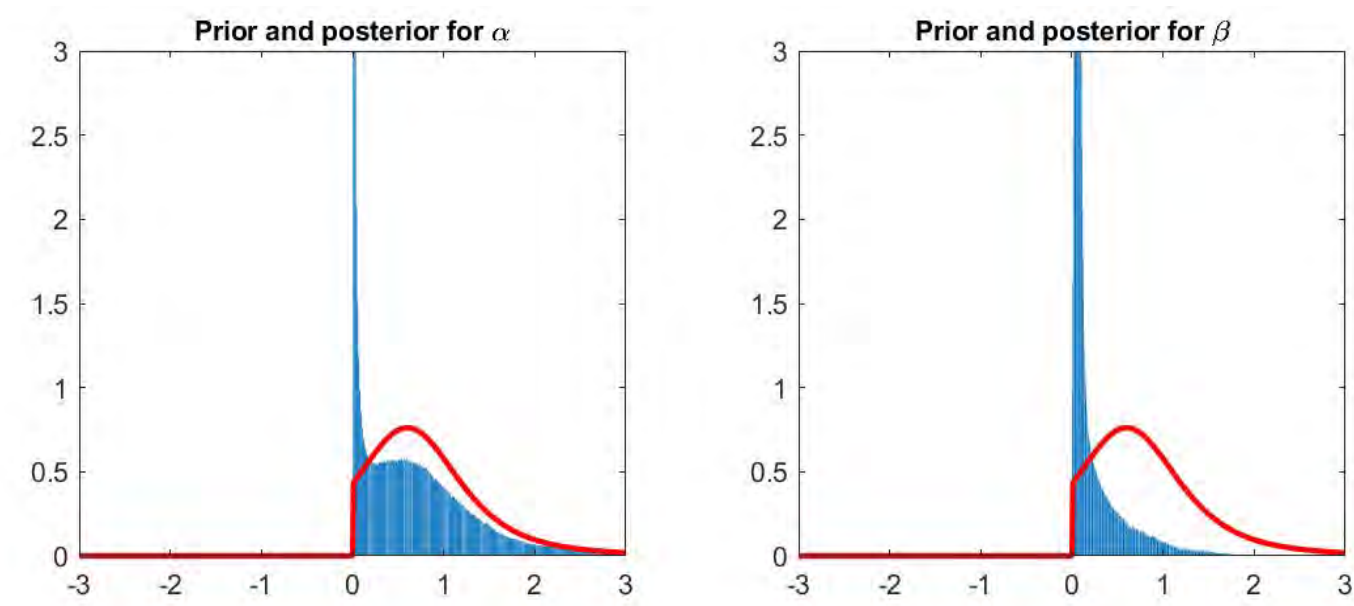

Posterior median (solid line) and 80 percent credible sets for the effects of 1 percent technology and fiscal policy shocks
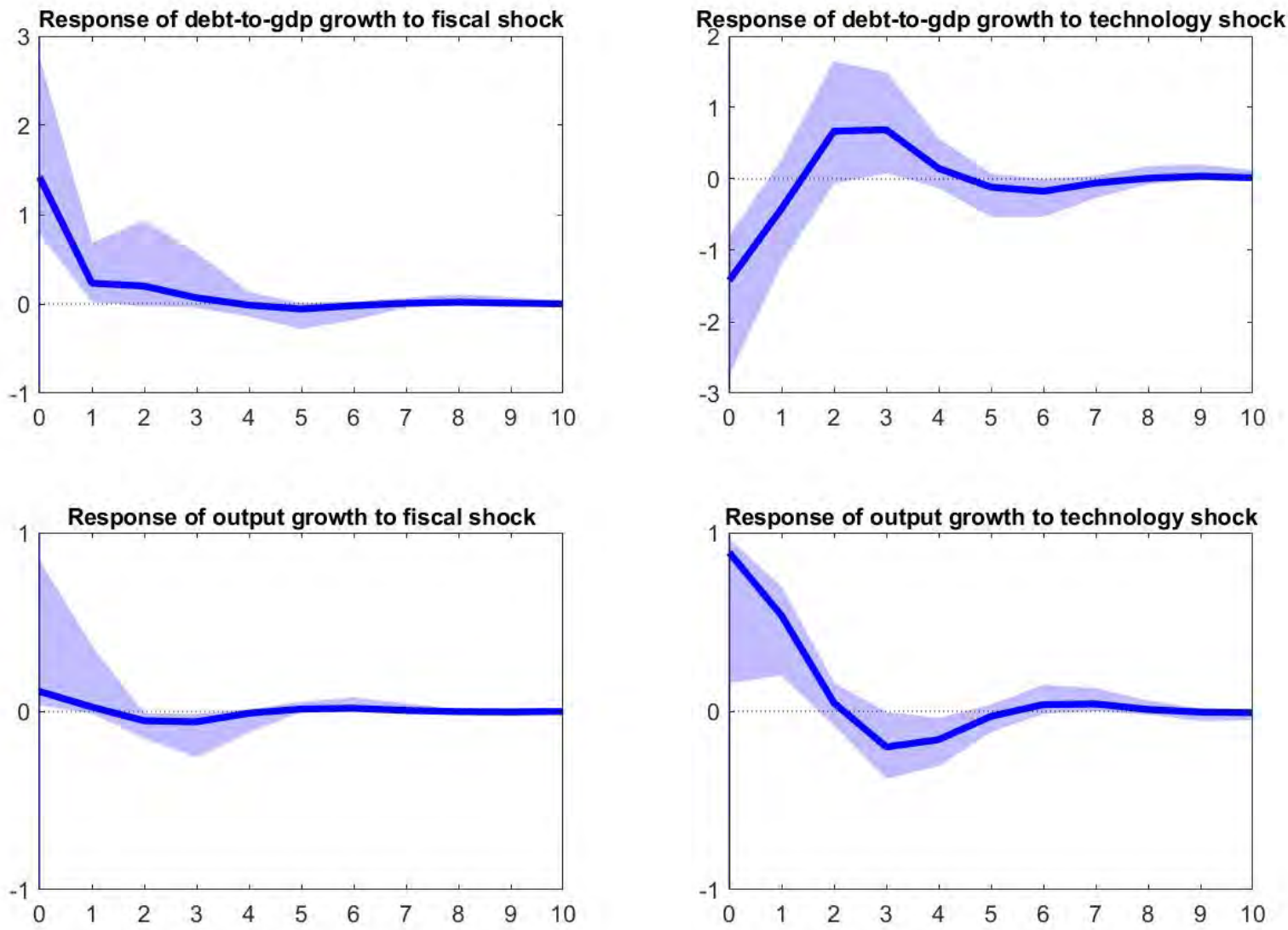
Figure S9: Posterior distributions of parameters $\alpha$ and $\beta$, and the effects of 1 percent technology and fiscal policy shocks for Ecuador

Posterior distributions of parameters $\alpha$ and $\beta$
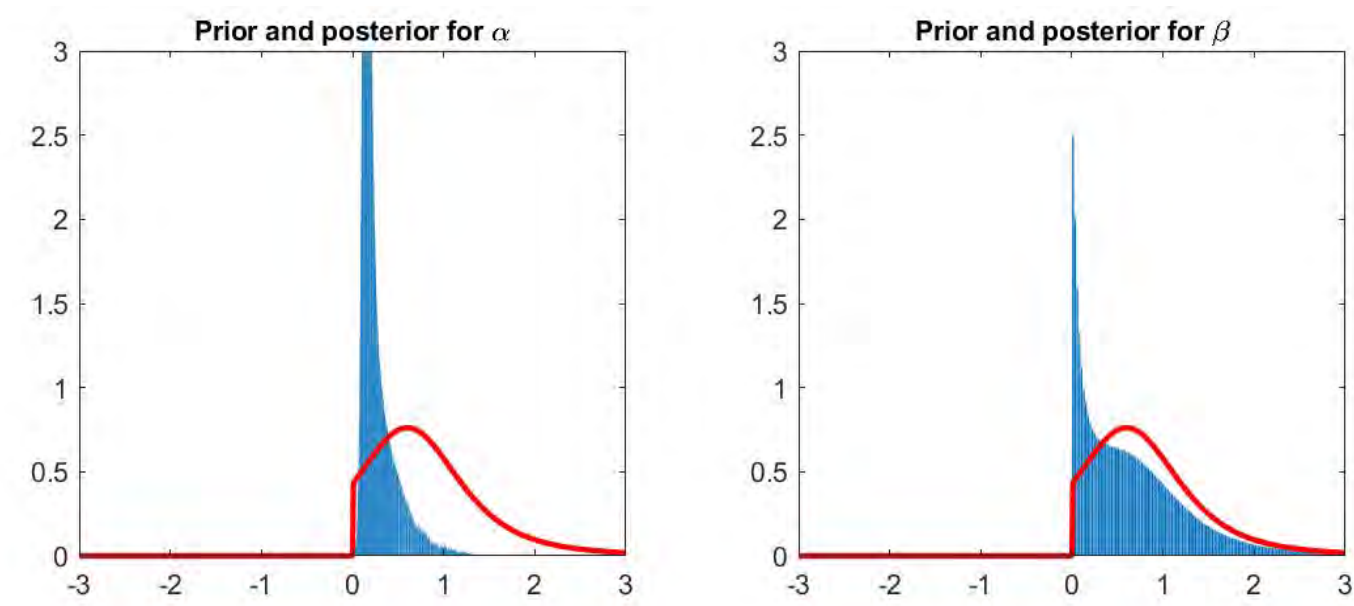

Posterior median (solid line) and 80 percent credible sets for the effects of 1 percent technology and fiscal policy shocks
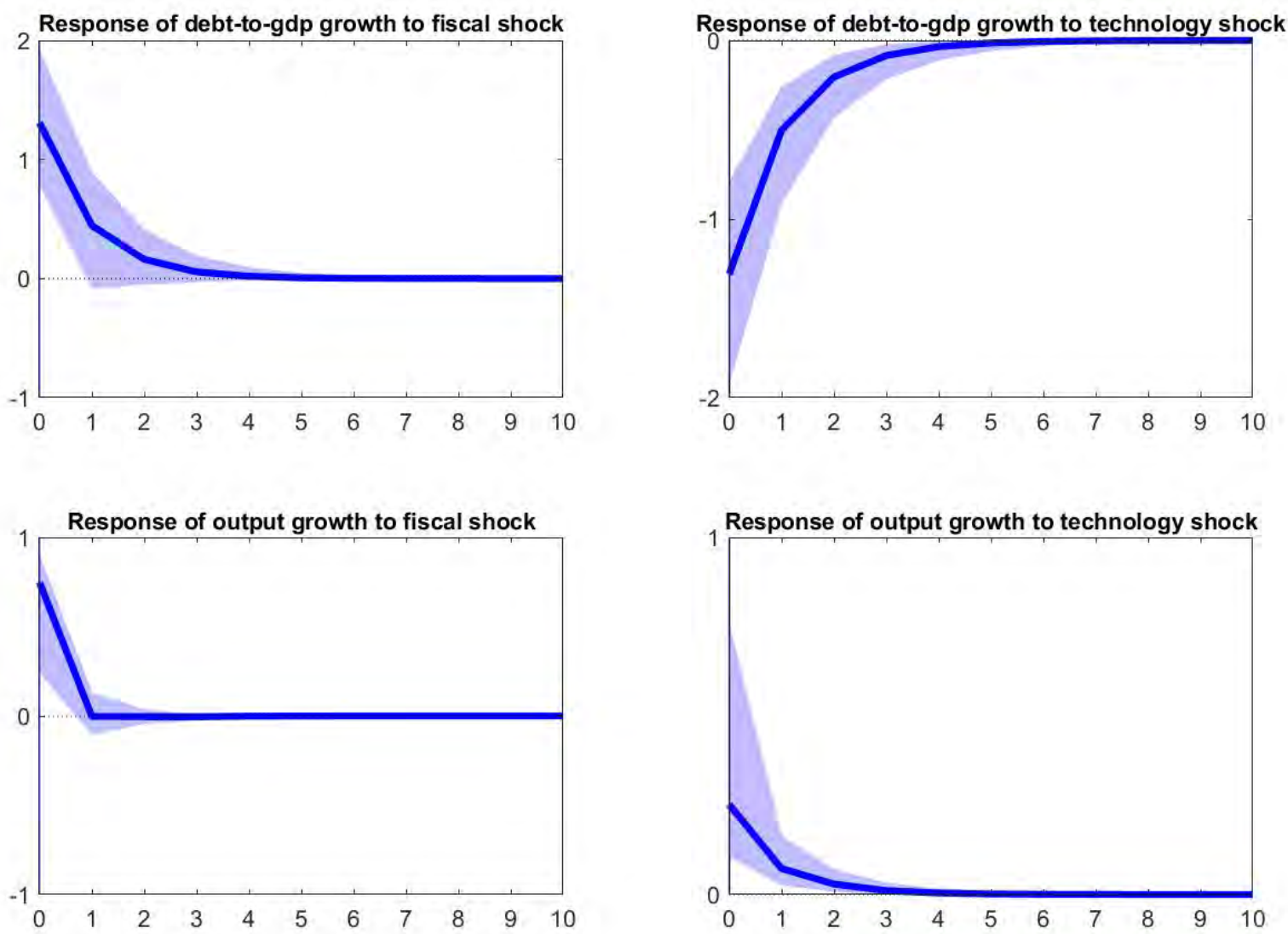
Figure S10: Posterior distributions of parameters $\alpha$ and $\beta$, and the effects of 1 percent technology and fiscal policy shocks for Egypt

Posterior distributions of parameters $\alpha$ and $\beta$
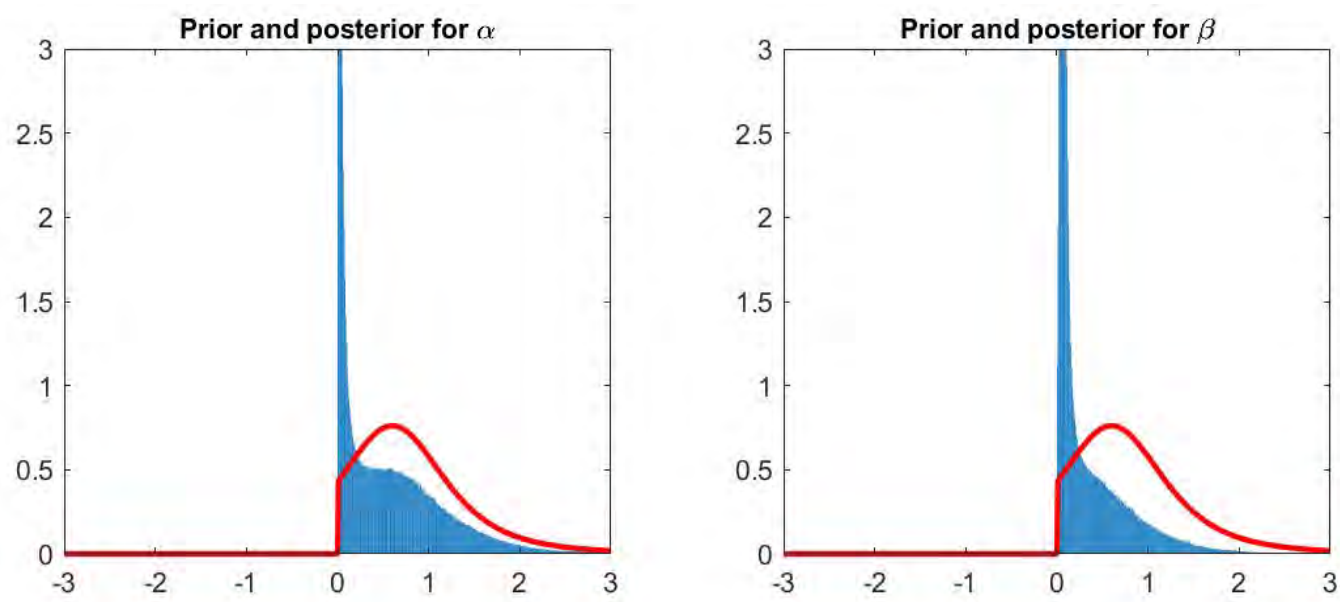

Posterior median (solid line) and 80 percent credible sets for the effects of 1 percent technology and fiscal policy shocks
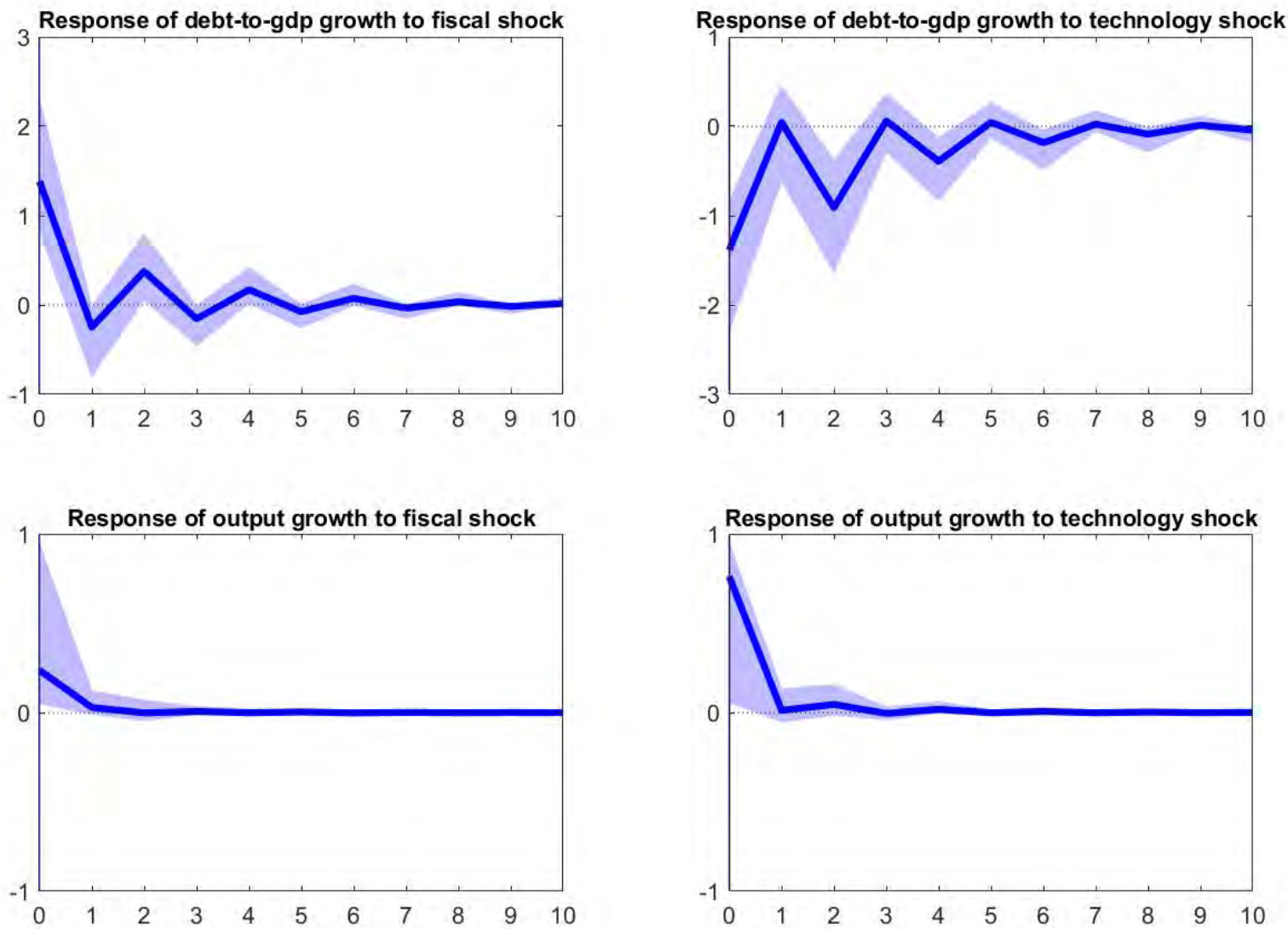
Figure S11: Posterior distributions of parameters $\alpha$ and $\beta$, and the effects of 1 percent technology and fiscal policy shocks for Finland

Posterior distributions of parameters $\alpha$ and $\beta$
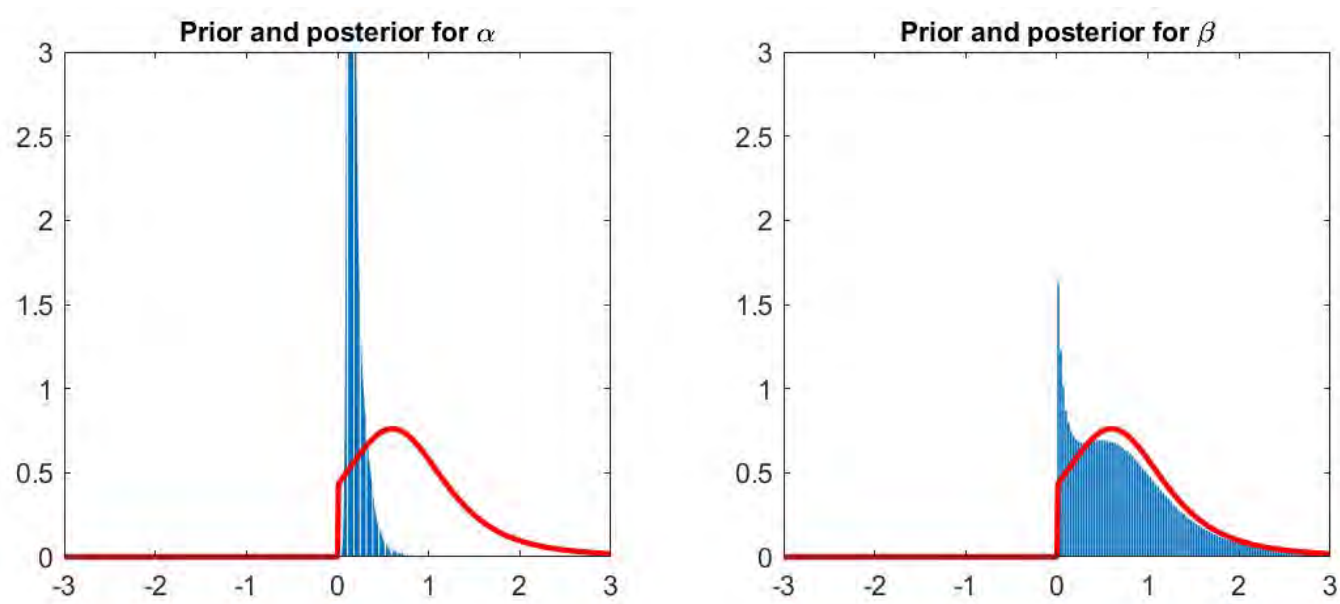

Posterior median (solid line) and 80 percent credible sets for the effects of 1 percent technology and fiscal policy shocks
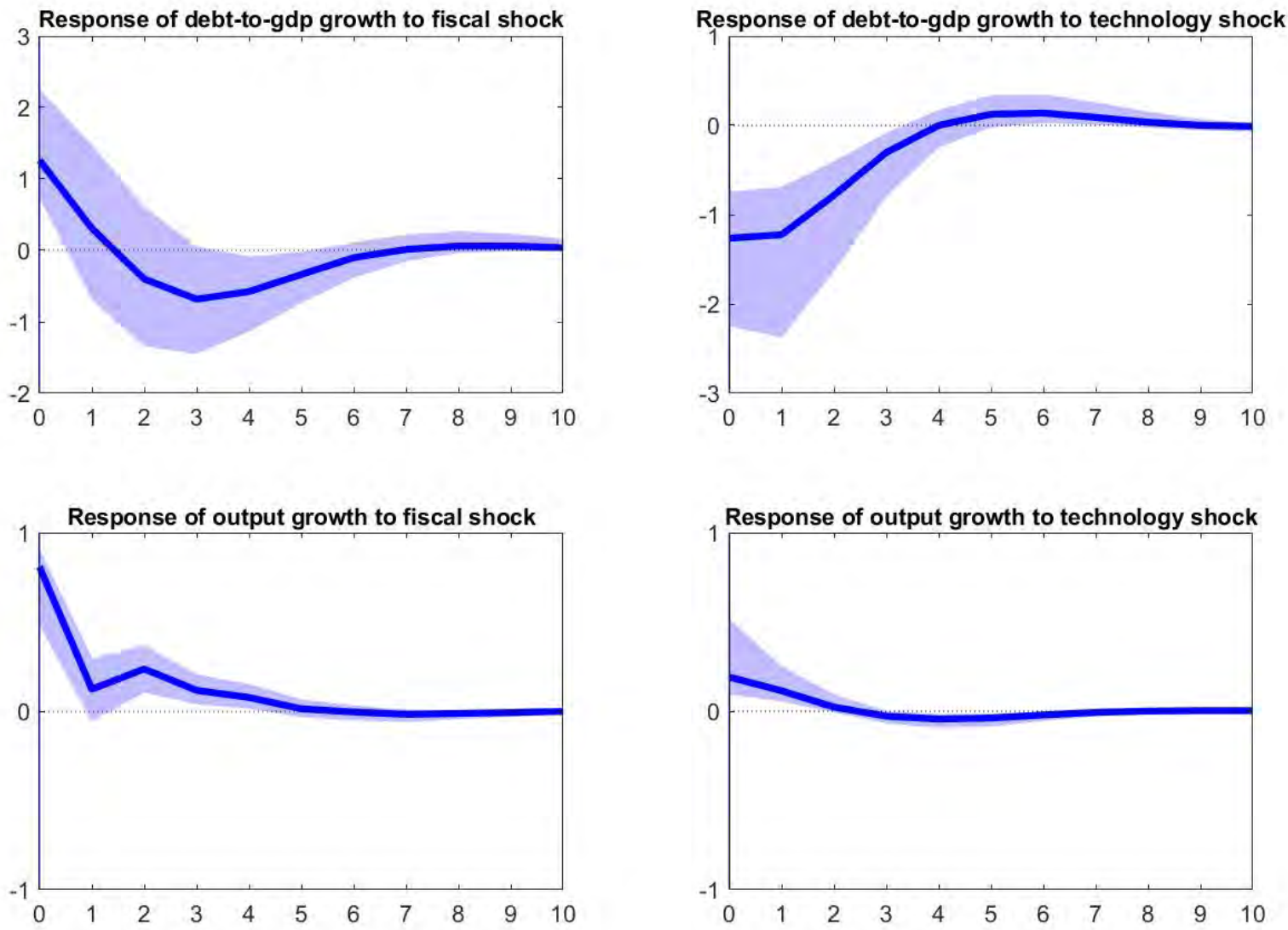
Figure S12: Posterior distributions of parameters $\alpha$ and $\beta$, and the effects of 1 percent technology and fiscal policy shocks for France

Posterior distributions of parameters $\alpha$ and $\beta$
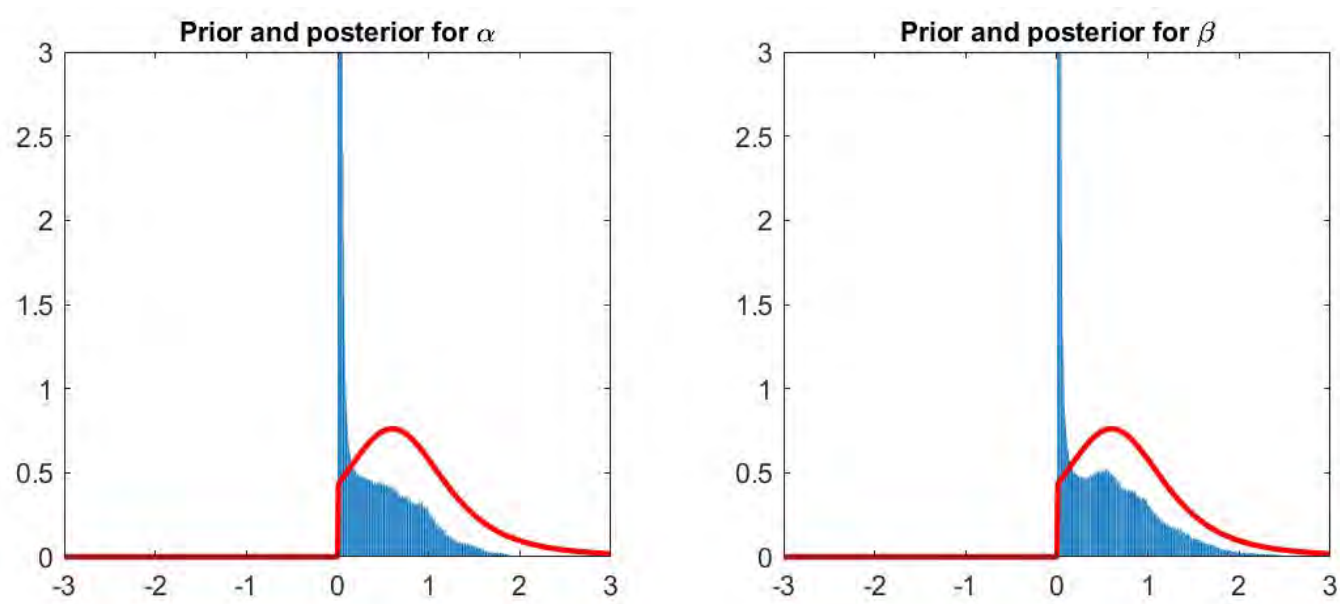

Posterior median (solid line) and 80 percent credible sets for the effects of 1 percent technology and fiscal policy shocks
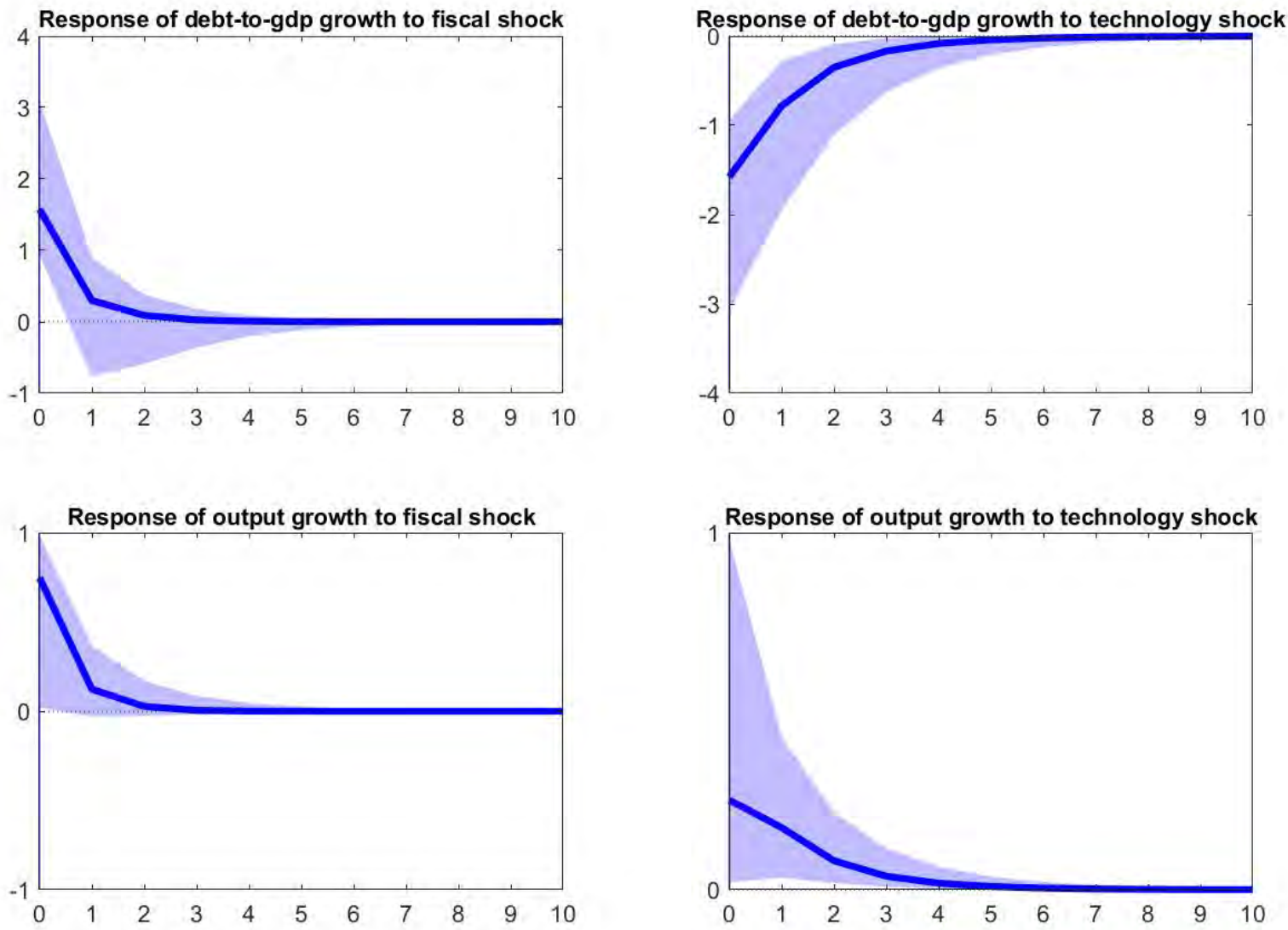
Figure S13: Posterior distributions of parameters $\alpha$ and $\beta$, and the effects of 1 percent technology and fiscal policy shocks for Germany

Posterior distributions of parameters $\alpha$ and $\beta$
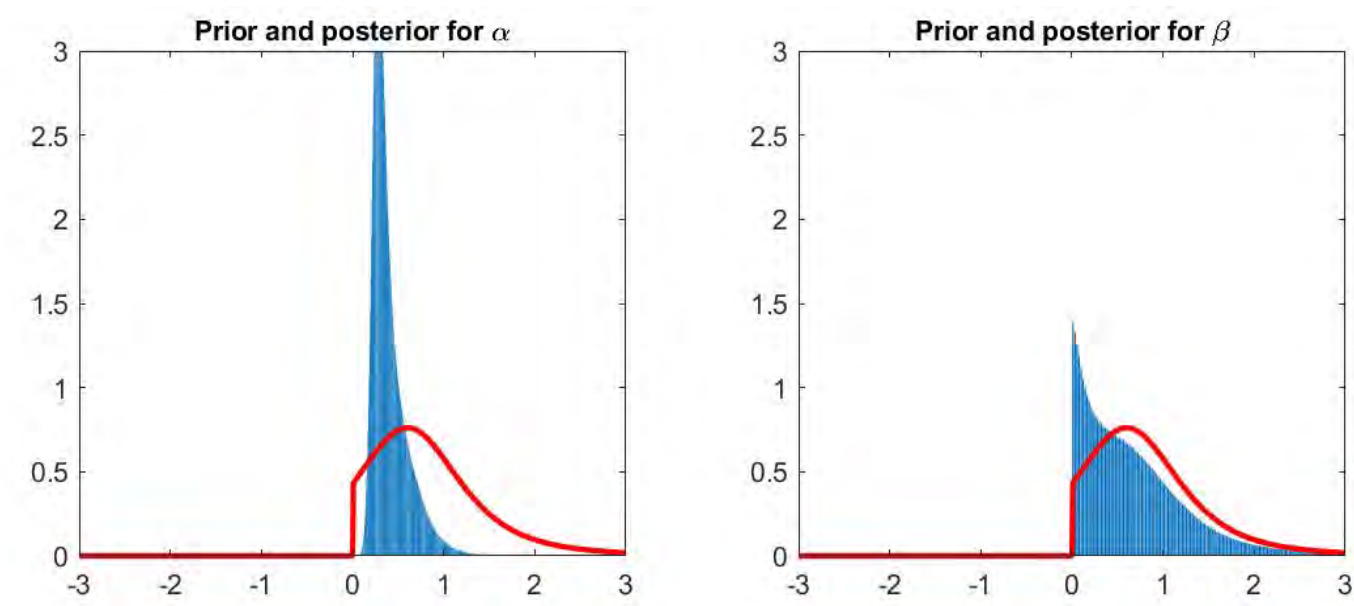

Posterior median (solid line) and 80 percent credible sets for the effects of 1 percent technology and fiscal policy shocks
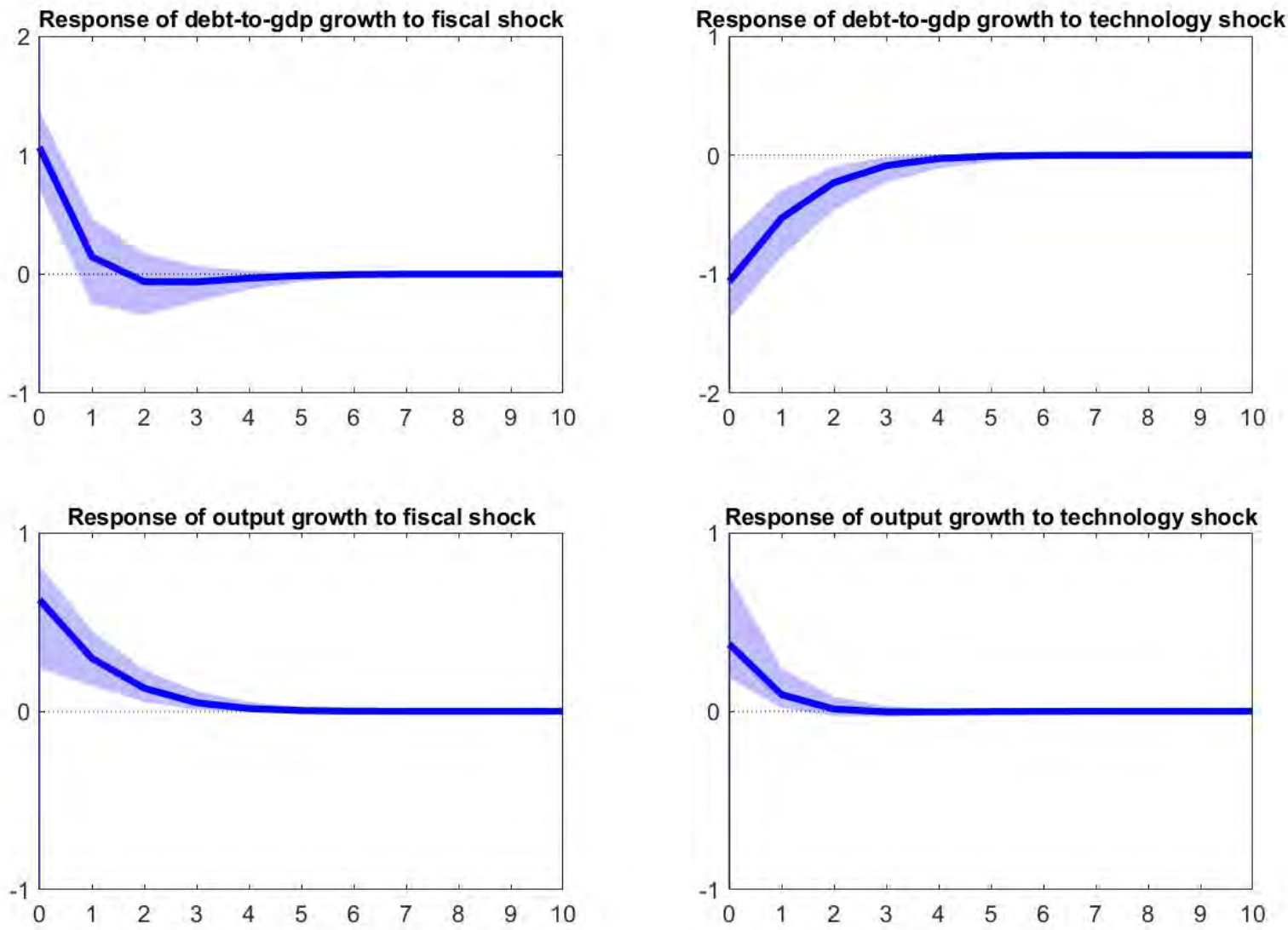
Figure S14: Posterior distributions of parameters $\alpha$ and $\beta$, and the effects of 1 percent technology and fiscal policy shocks for India

Posterior distributions of parameters $\alpha$ and $\beta$
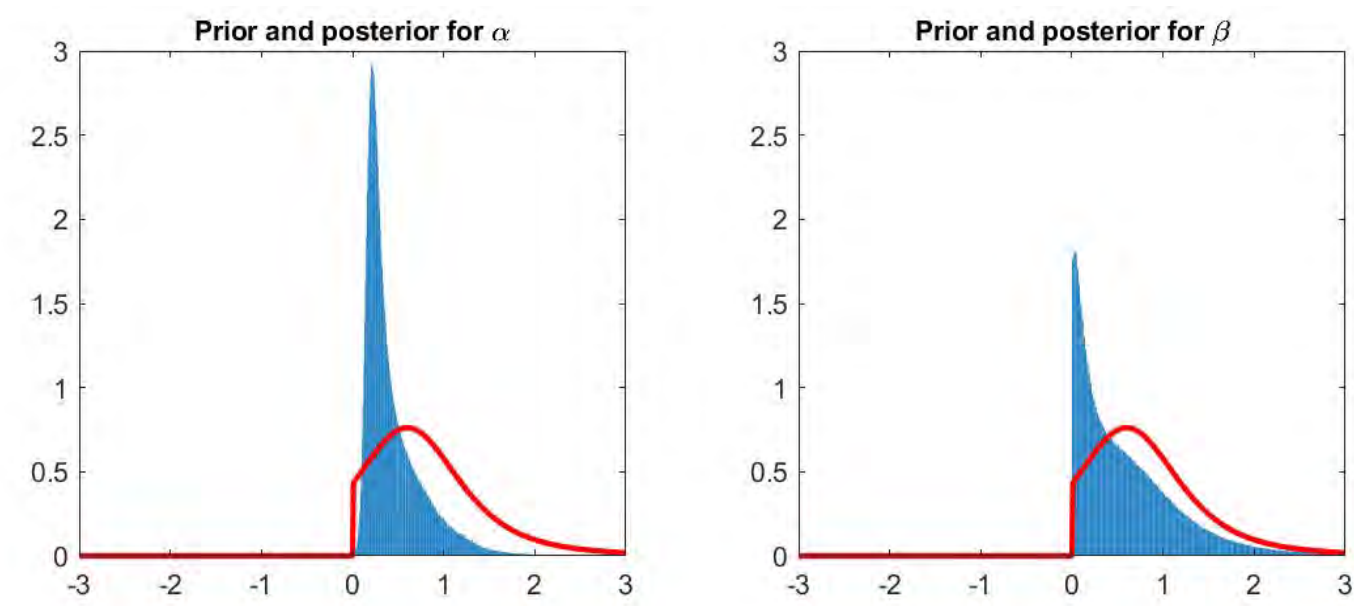

Posterior median (solid line) and 80 percent credible sets for the effects of 1 percent technology and fiscal policy shocks
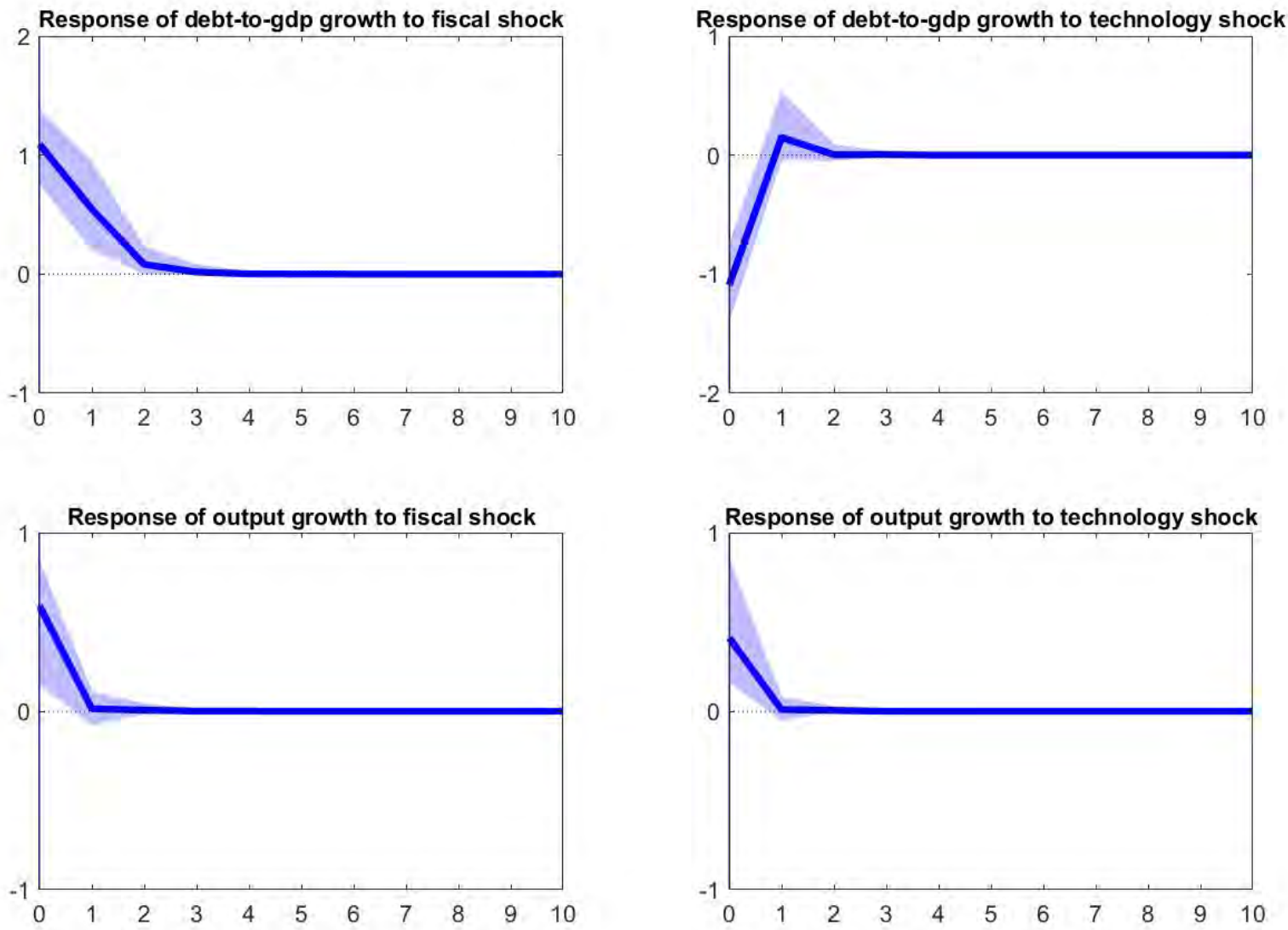
Figure S15: Posterior distributions of parameters $\alpha$ and $\beta$, and the effects of 1 percent technology and fiscal policy shocks for Indonesia

Posterior distributions of parameters $\alpha$ and $\beta$
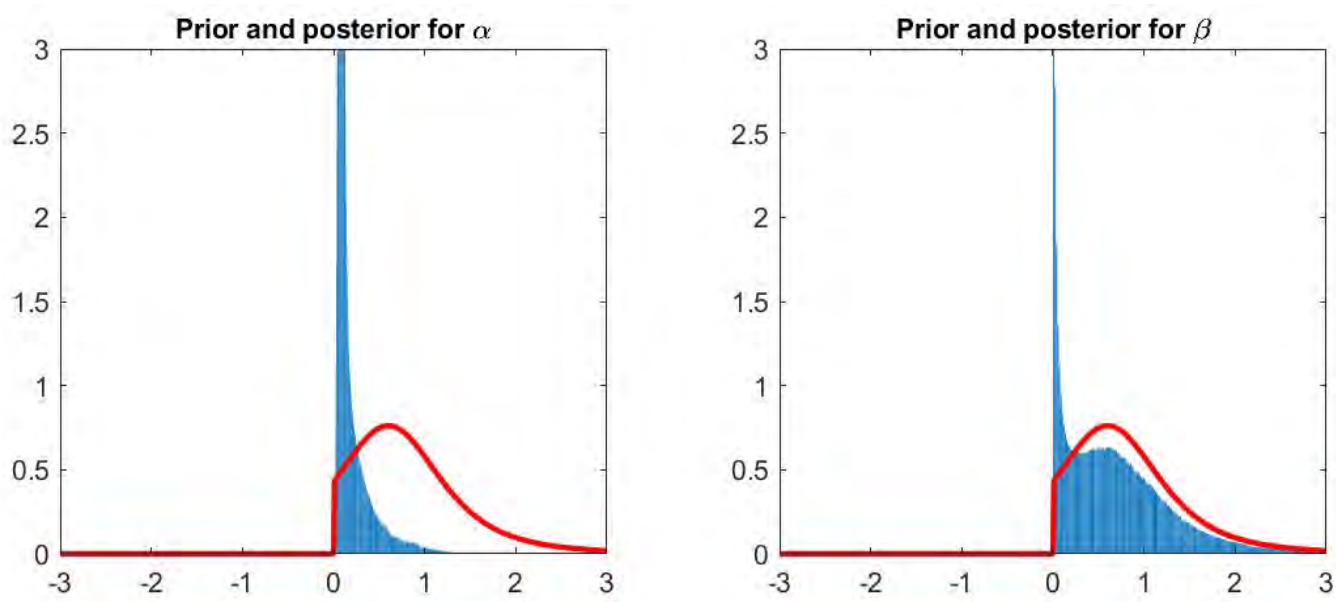

Posterior median (solid line) and 80 percent credible sets for the effects of 1 percent technology and fiscal policy shocks
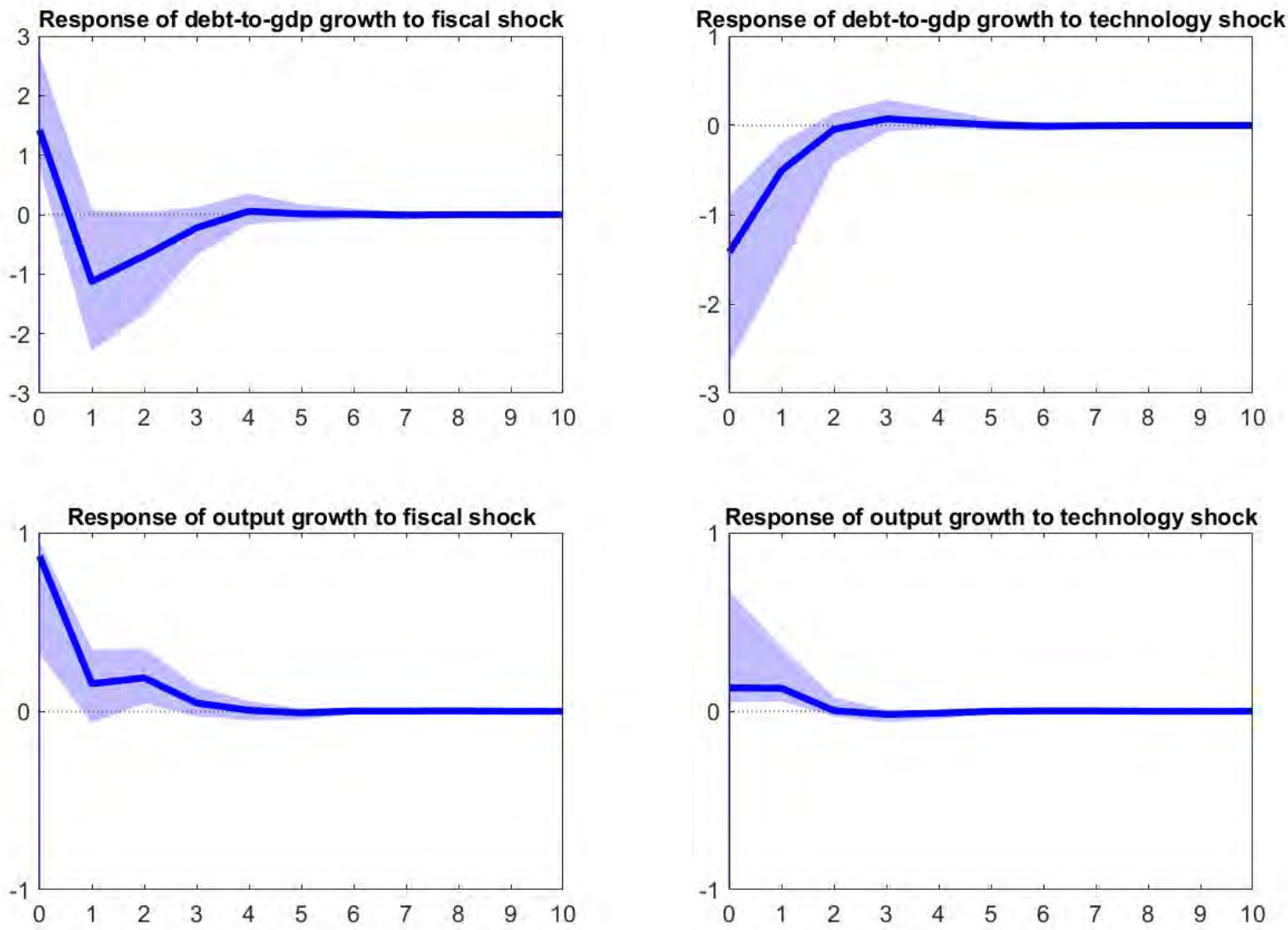
Figure S16: Posterior distributions of parameters $\alpha$ and $\beta$, and the effects of 1 percent technology and fiscal policy shocks for Iran

Posterior distributions of parameters $\alpha$ and $\beta$
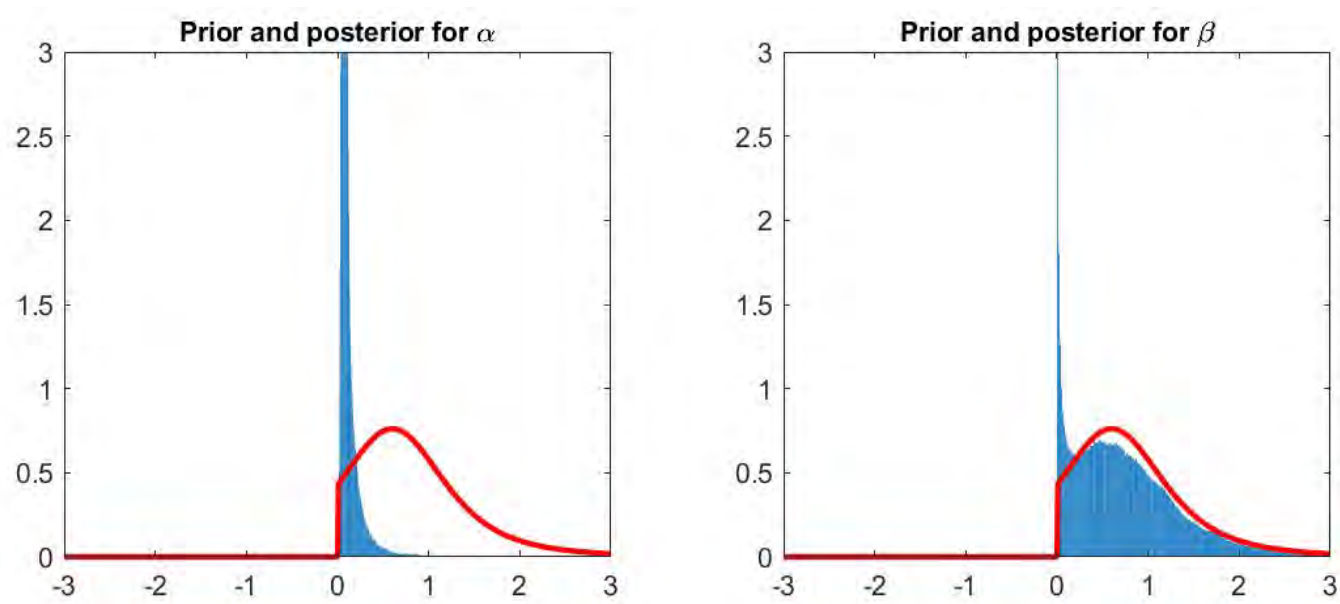

Posterior median (solid line) and 80 percent credible sets for the effects of 1 percent technology and fiscal policy shocks
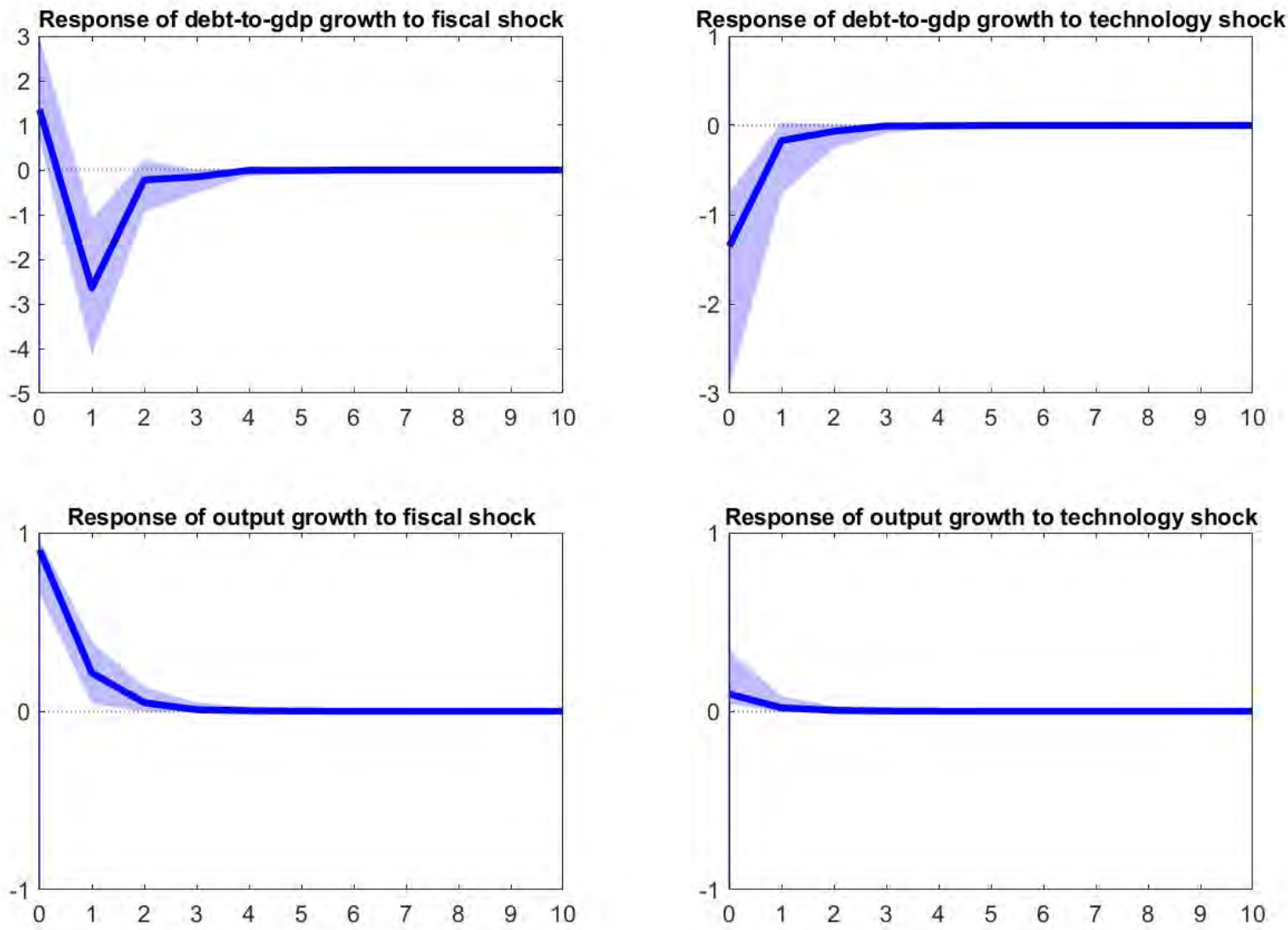
Figure S17: Posterior distributions of parameters $\alpha$ and $\beta$, and the effects of 1 percent technology and fiscal policy shocks for Italy

Posterior distributions of parameters $\alpha$ and $\beta$
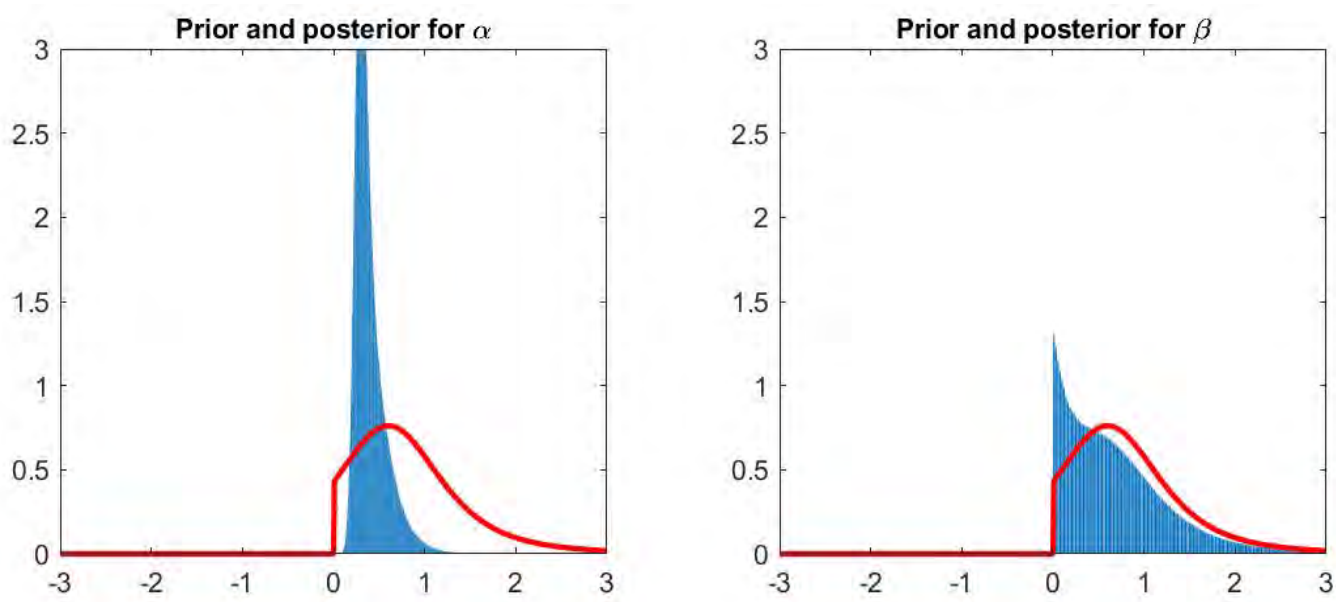

Posterior median (solid line) and 80 percent credible sets for the effects of 1 percent technology and fiscal policy shocks
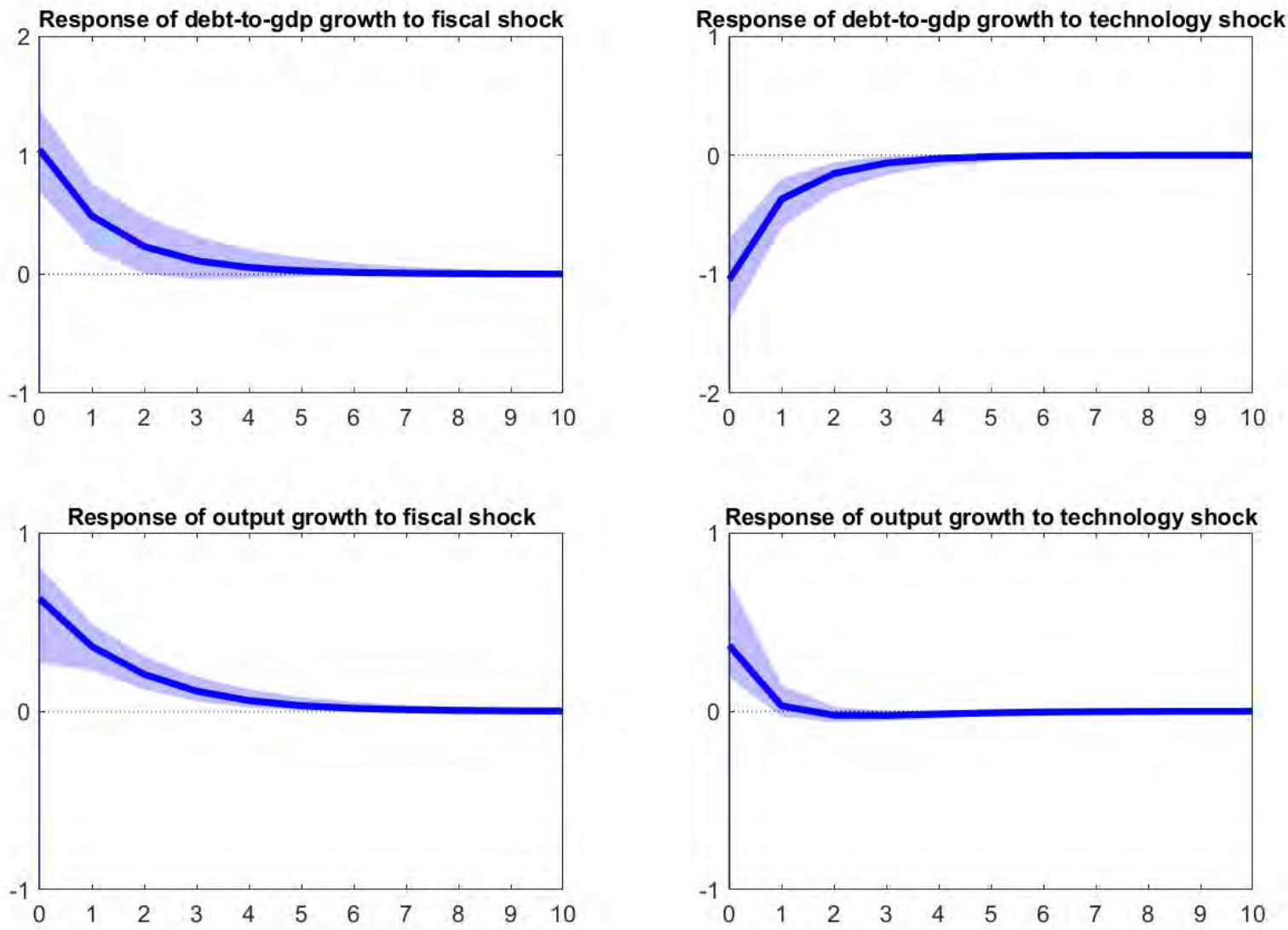
Figure S18: Posterior distributions of parameters $\alpha$ and $\beta$, and the effects of 1 percent technology and fiscal policy shocks for Japan

Posterior distributions of parameters $\alpha$ and $\beta$
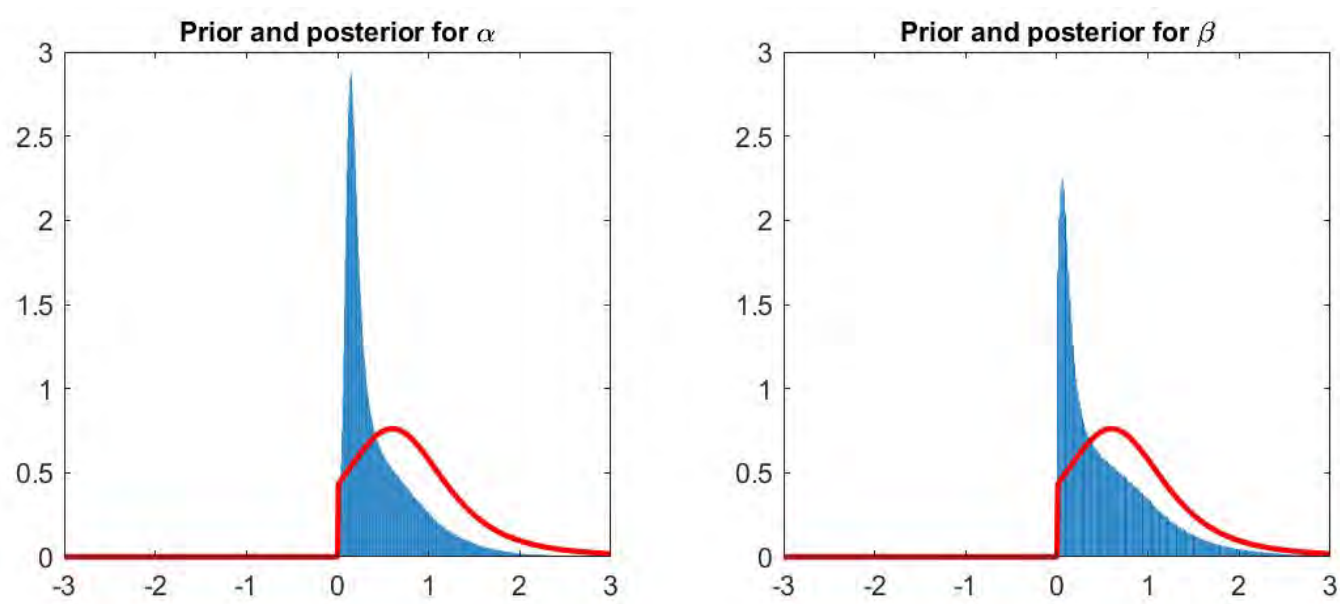

Posterior median (solid line) and 80 percent credible sets for the effects of 1 percent technology and fiscal policy shocks
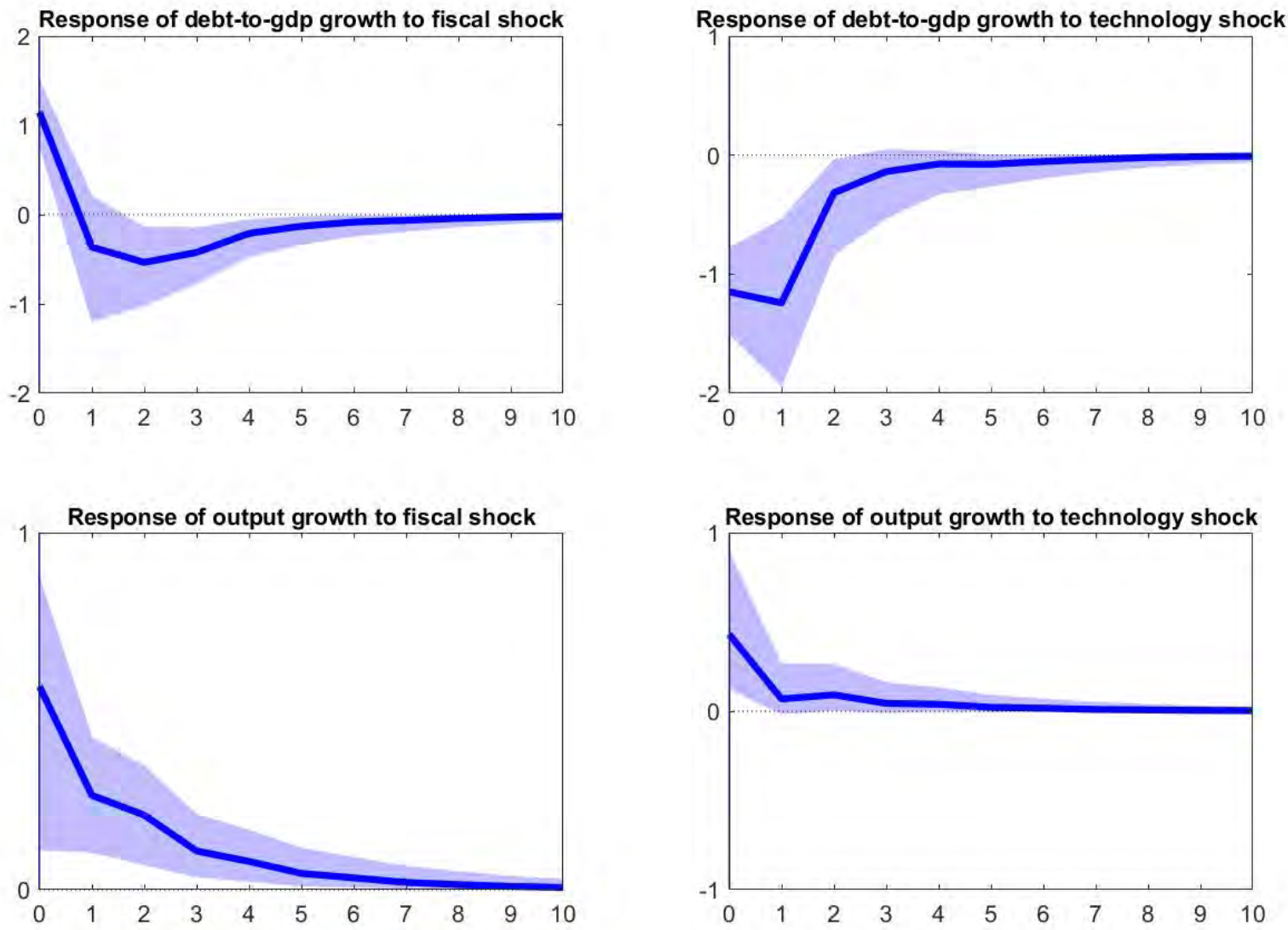
Figure S19: Posterior distributions of parameters $\alpha$ and $\beta$, and the effects of 1 percent technology and fiscal policy shocks for Korea

Posterior distributions of parameters $\alpha$ and $\beta$
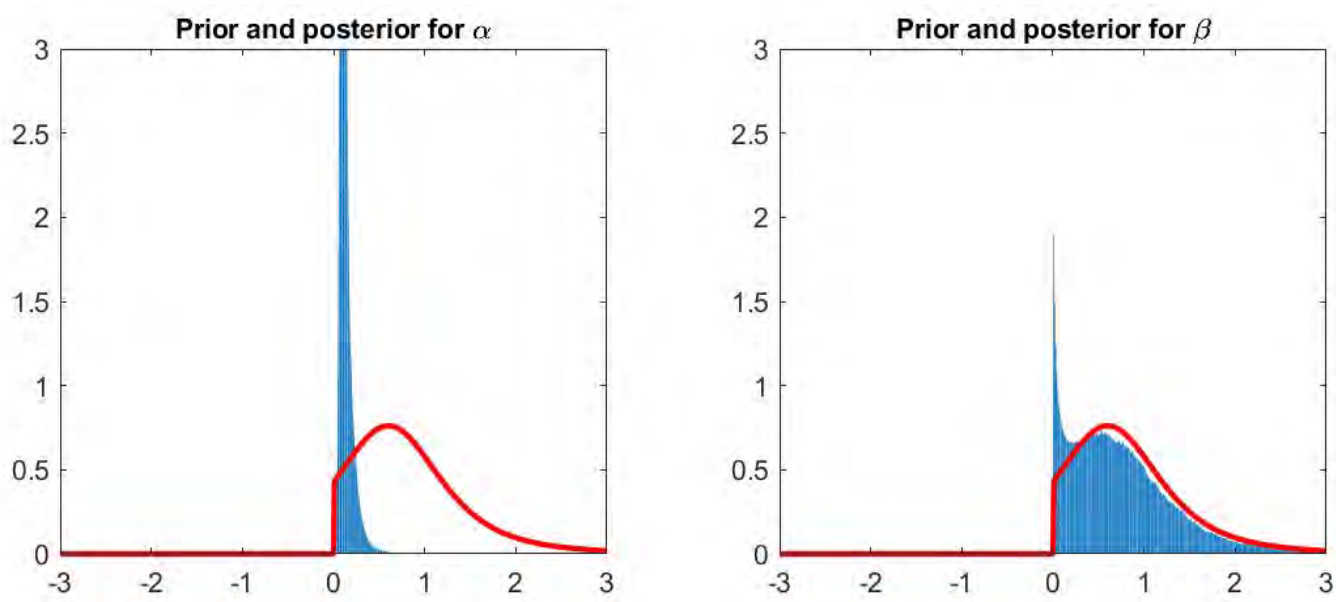

Posterior median (solid line) and 80 percent credible sets for the effects of 1 percent technology and fiscal policy shocks
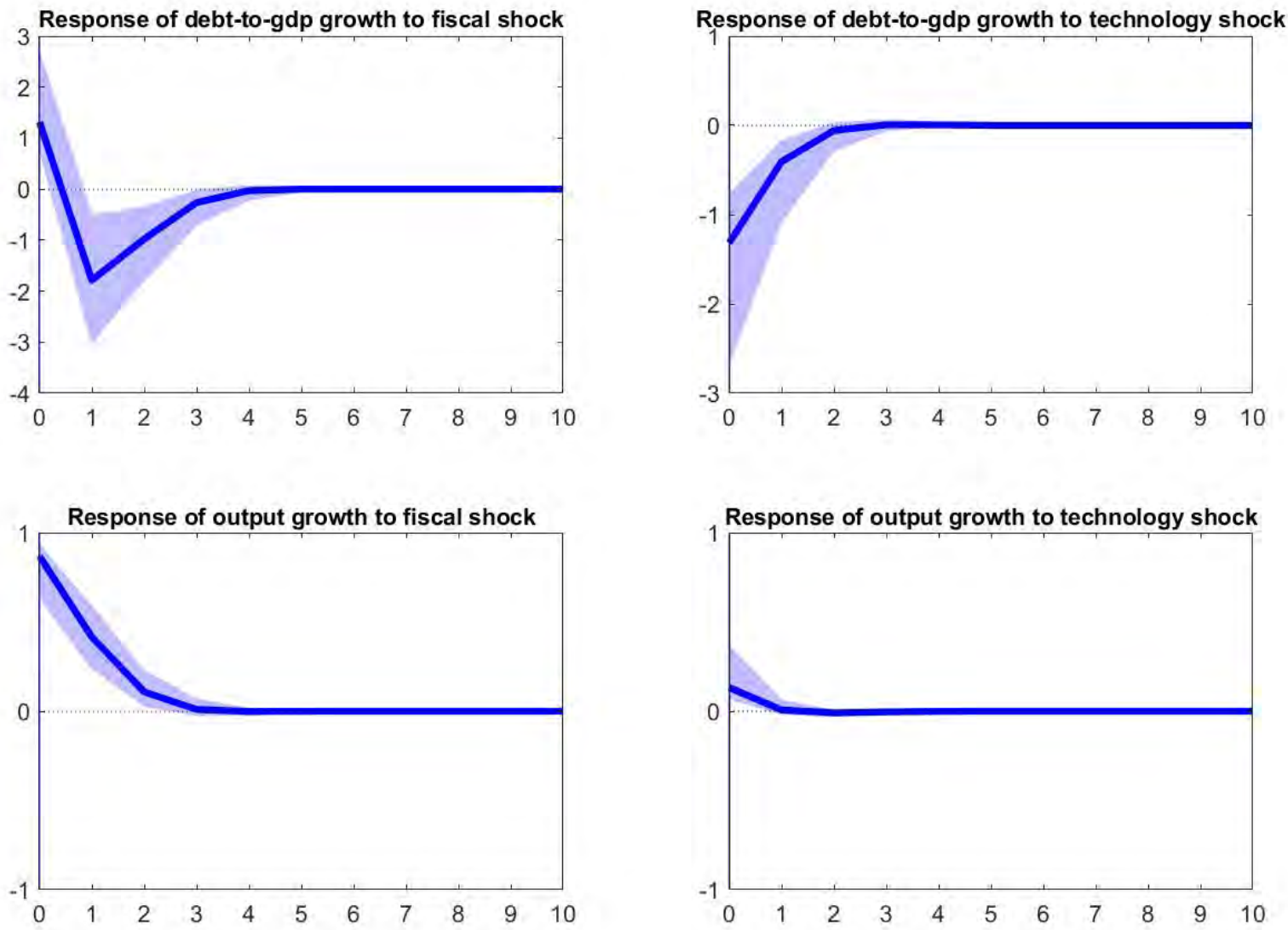
Figure S20: Posterior distributions of parameters $\alpha$ and $\beta$, and the effects of 1 percent technology and fiscal policy shocks for Malaysia

Posterior distributions of parameters $\alpha$ and $\beta$
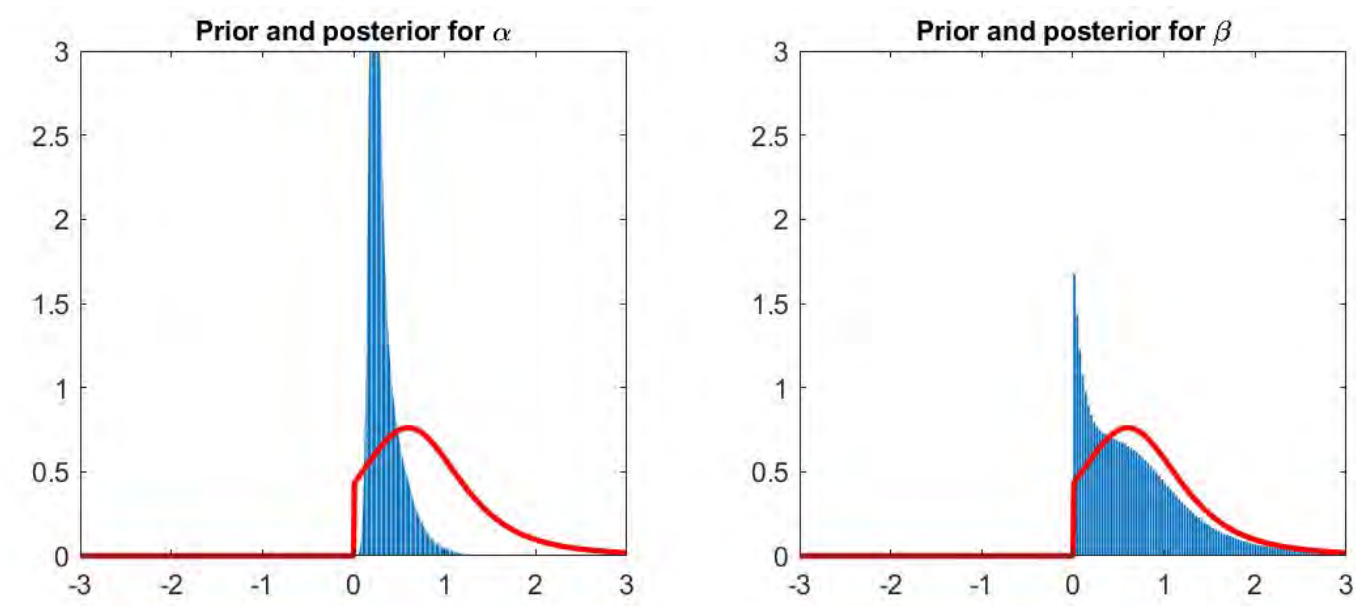

Posterior median (solid line) and 80 percent credible sets for the effects of 1 percent technology and fiscal policy shocks
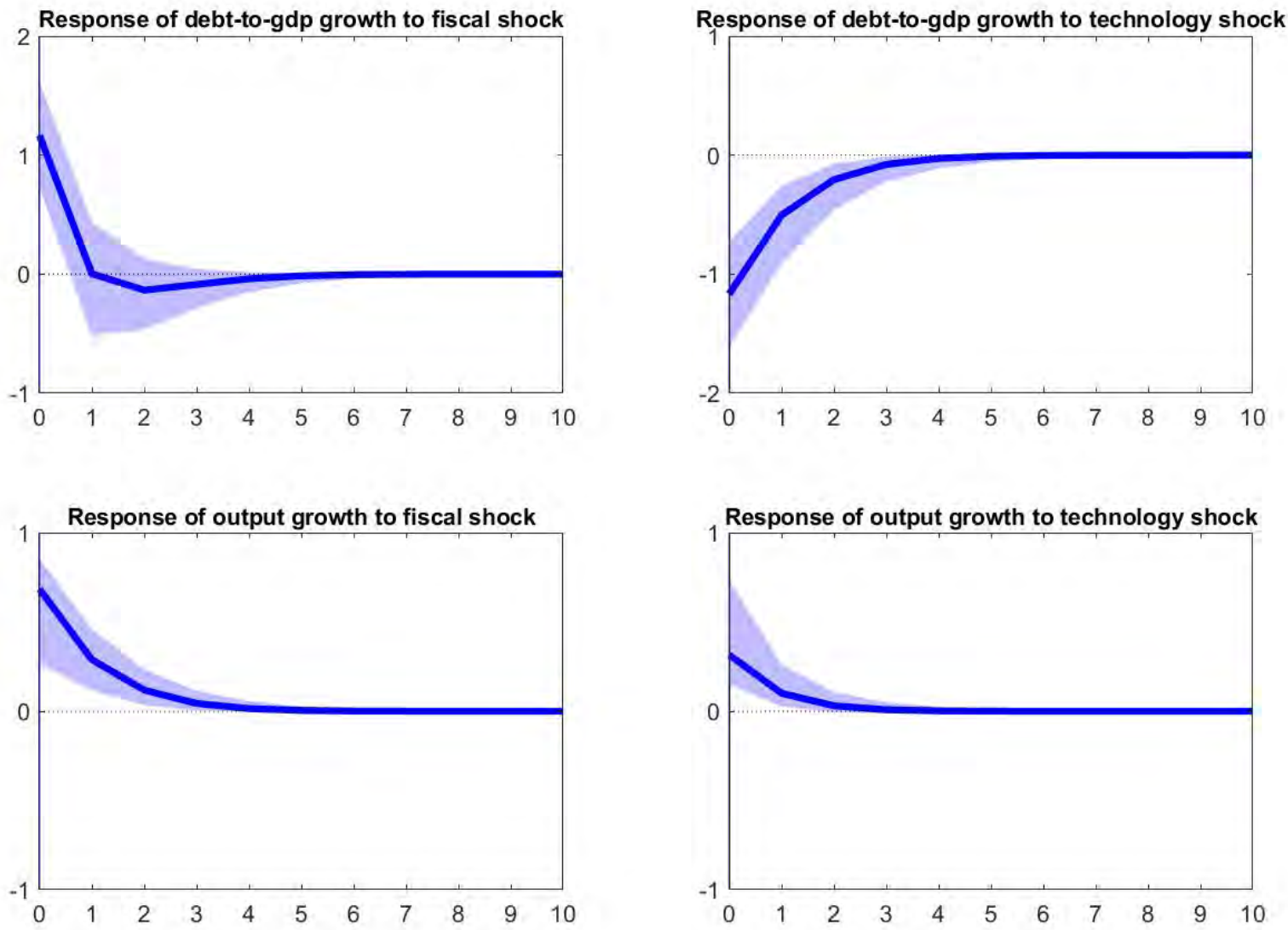
Figure S21: Posterior distributions of parameters $\alpha$ and $\beta$, and the effects of 1 percent technology and fiscal policy shocks for Mexico

Posterior distributions of parameters $\alpha$ and $\beta$
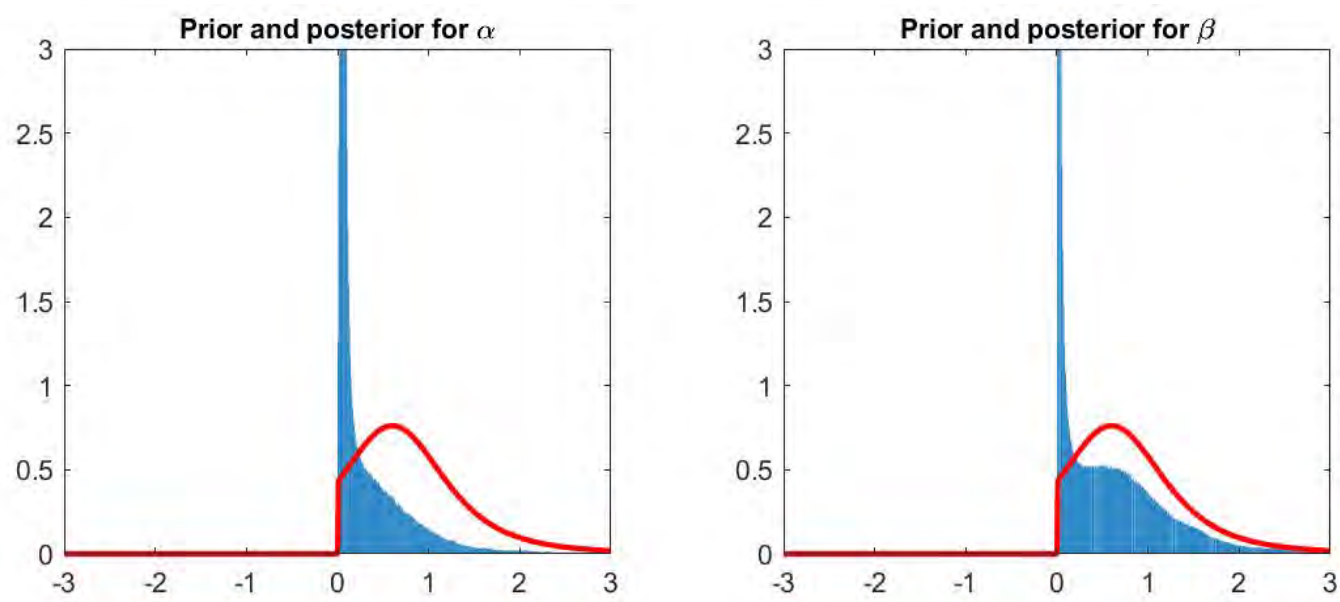

Posterior median (solid line) and 80 percent credible sets for the effects of 1 percent technology and fiscal policy shocks
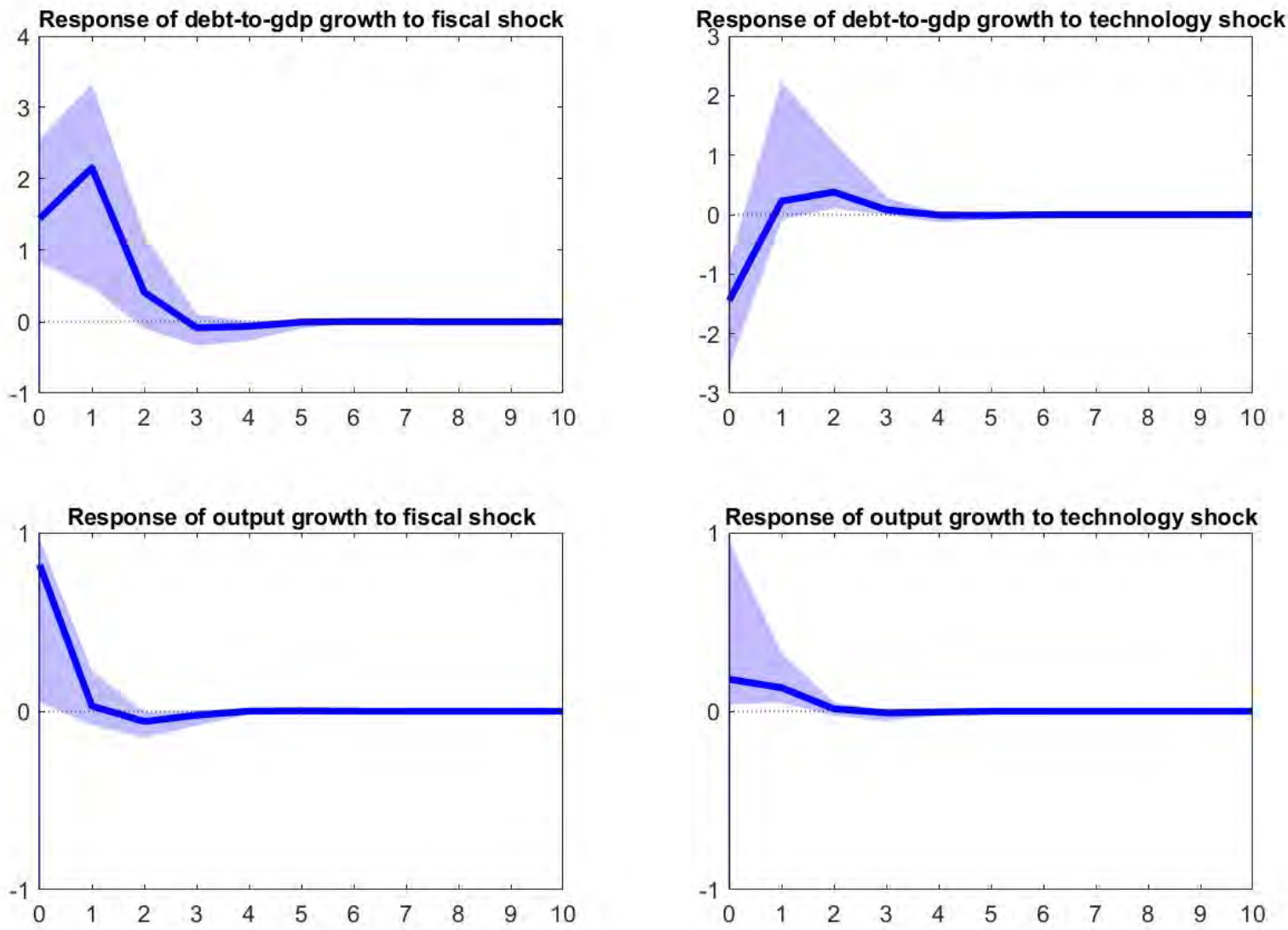
Figure S22: Posterior distributions of parameters $\alpha$ and $\beta$, and the effects of 1 percent technology and fiscal policy shocks for Morocco

Posterior distributions of parameters $\alpha$ and $\beta$
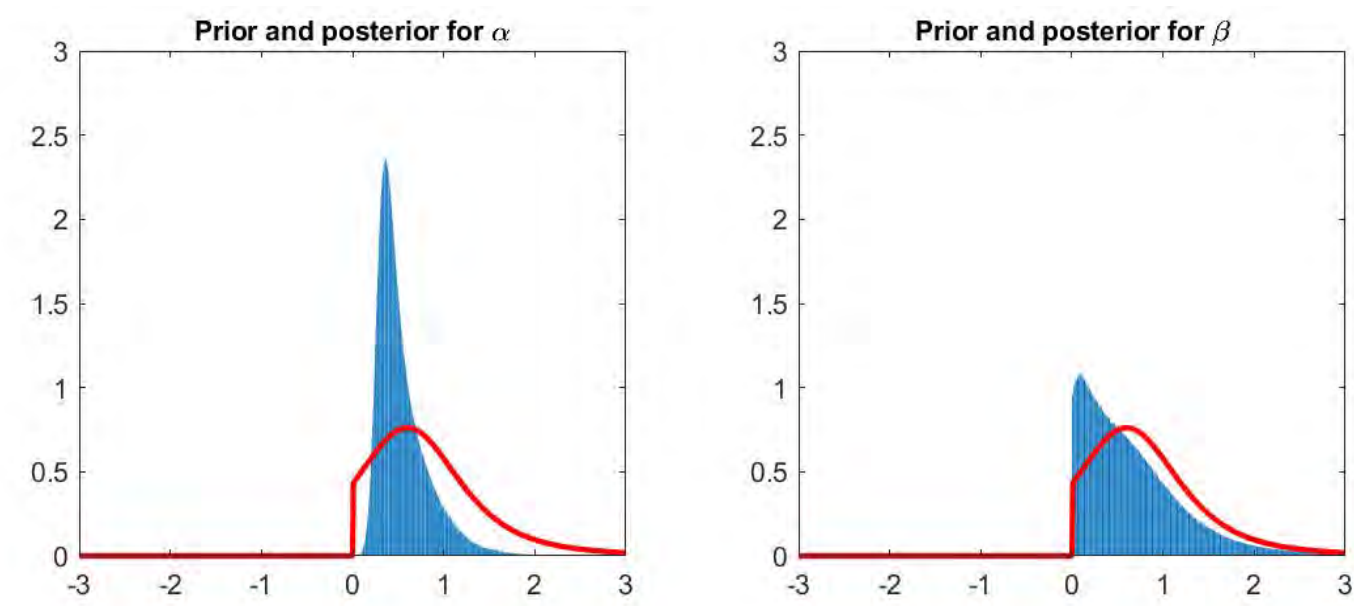

Posterior median (solid line) and 80 percent credible sets for the effects of 1 percent technology and fiscal policy shocks
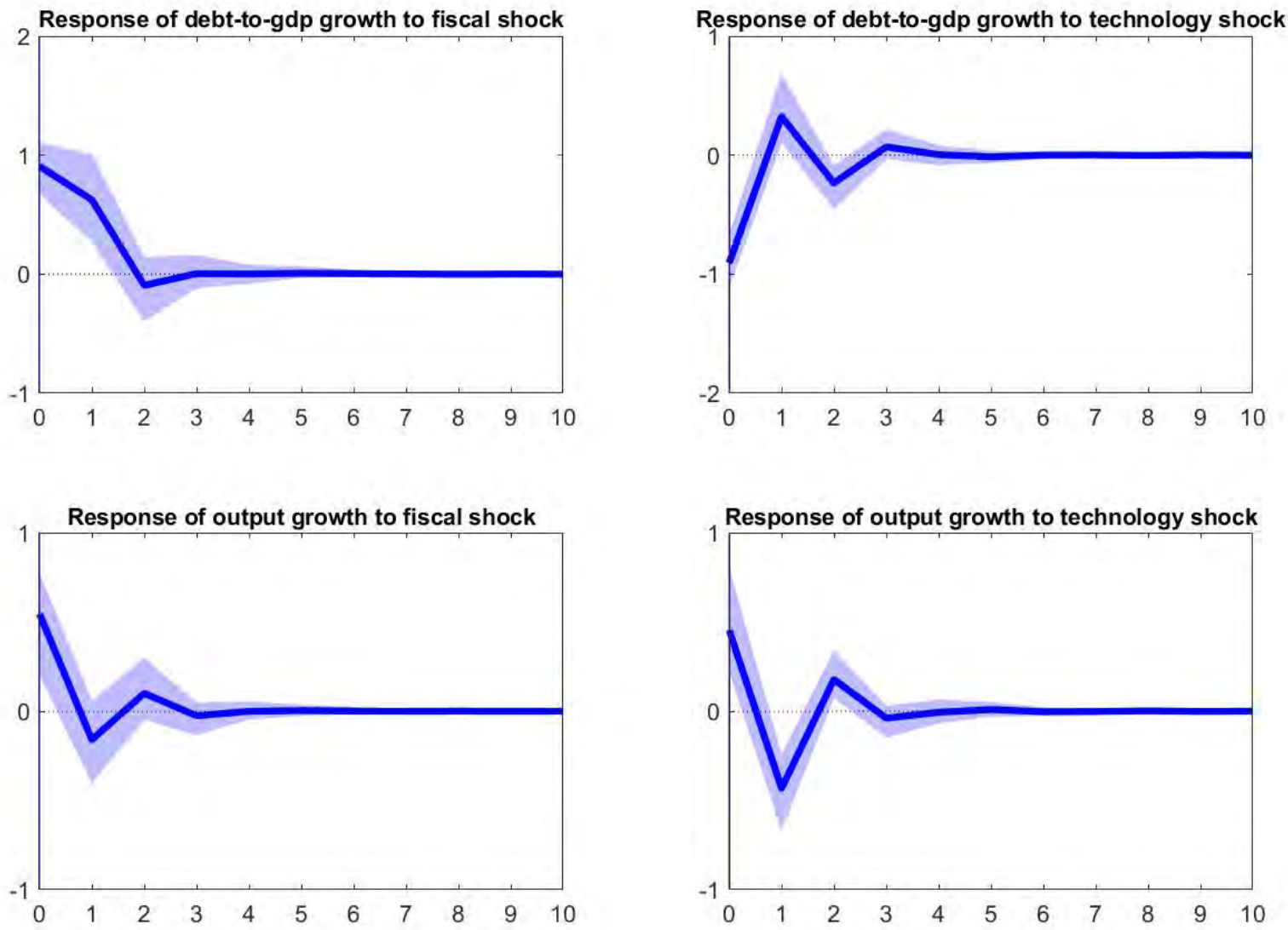
Figure S23: Posterior distributions of parameters $\alpha$ and $\beta$, and the effects of 1 percent technology and fiscal policy shocks for Netherlands

Posterior distributions of parameters $\alpha$ and $\beta$
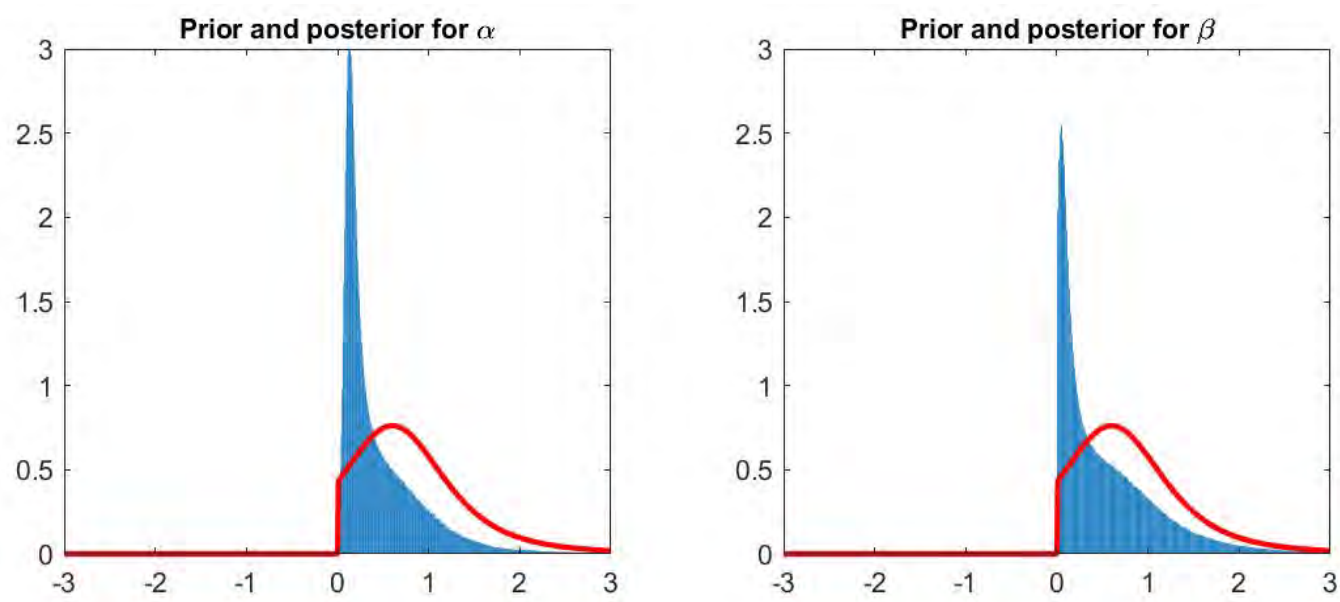

Posterior median (solid line) and 80 percent credible sets for the effects of 1 percent technology and fiscal policy shocks
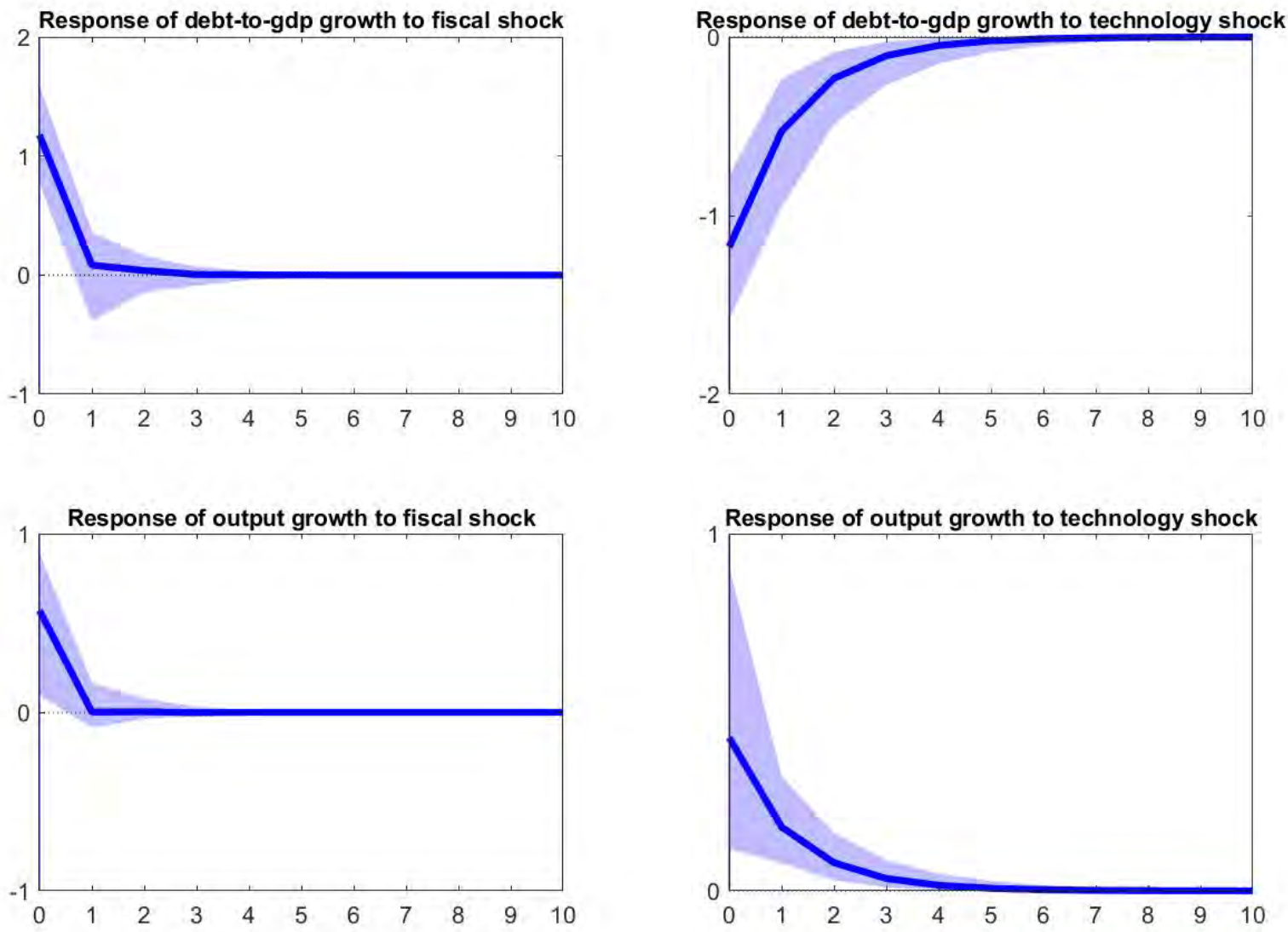
Figure S24: Posterior distributions of parameters $\alpha$ and $\beta$, and the effects of 1 percent technology and fiscal policy shocks for New Zealand

Posterior distributions of parameters $\alpha$ and $\beta$
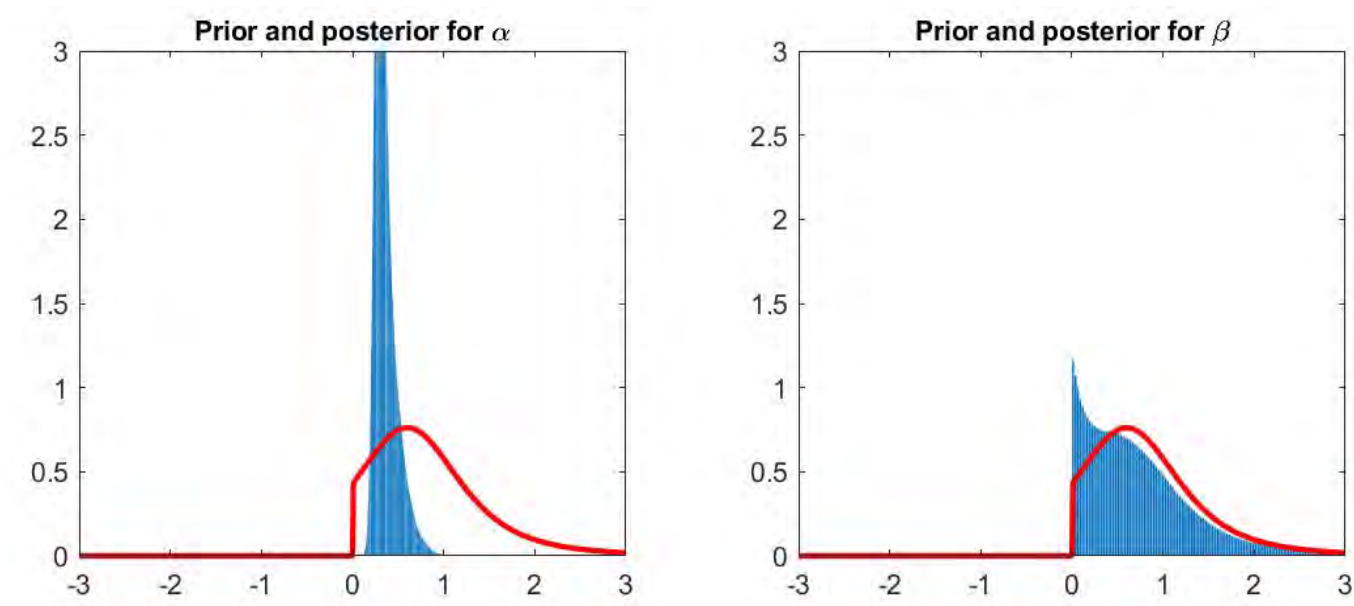

Posterior median (solid line) and 80 percent credible sets for the effects of 1 percent technology and fiscal policy shocks
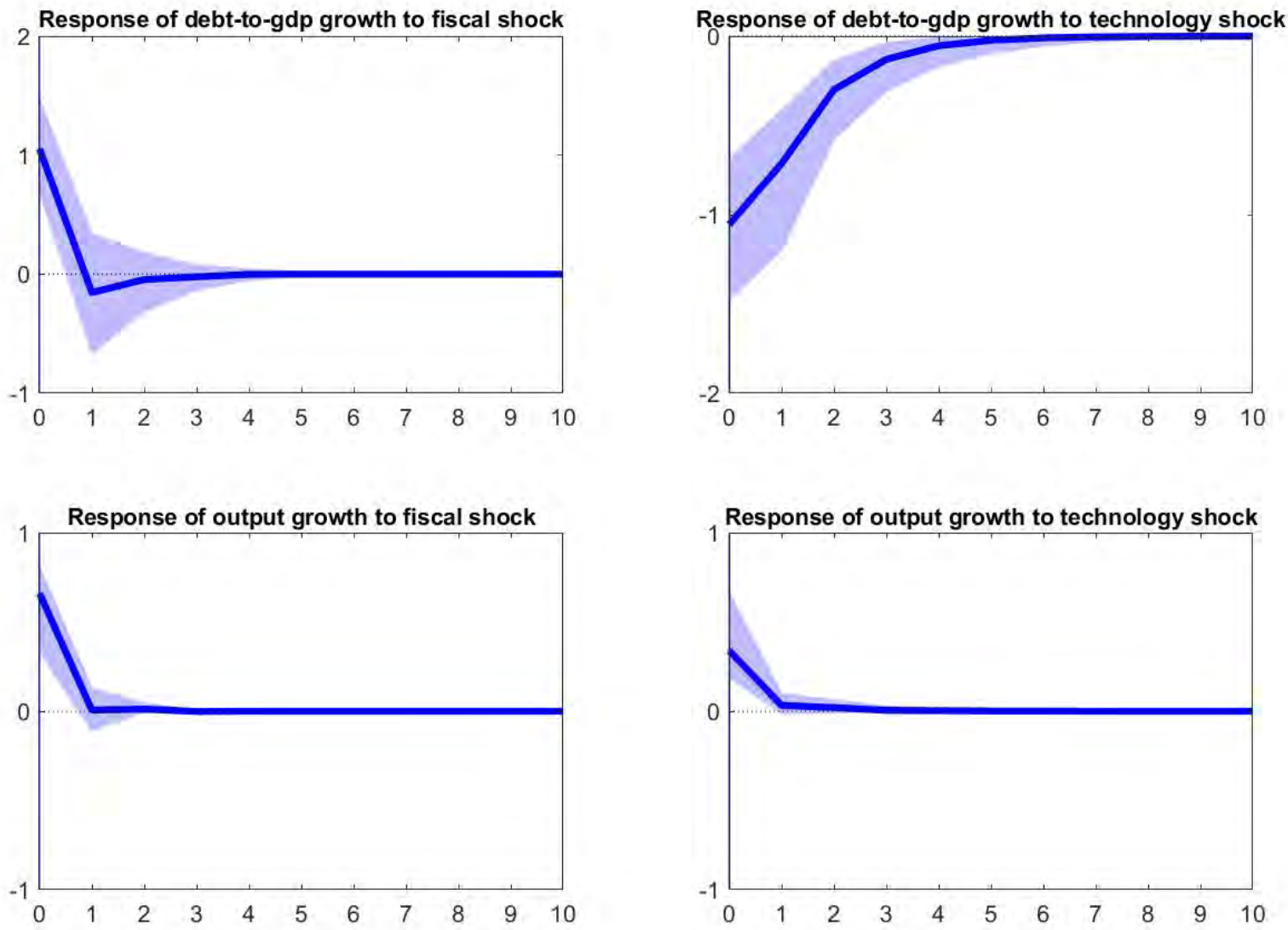
Figure S25: Posterior distributions of parameters $\alpha$ and $\beta$, and the effects of 1 percent technology and fiscal policy shocks for Nigeria

Posterior distributions of parameters $\alpha$ and $\beta$
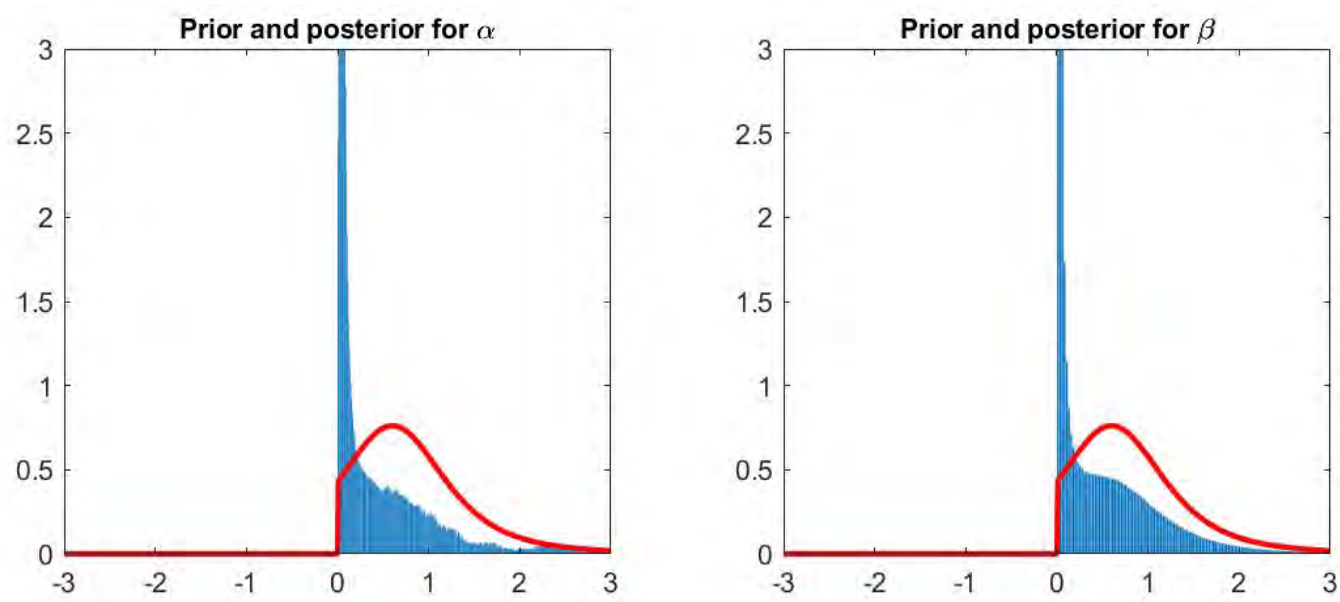

Posterior median (solid line) and 80 percent credible sets for the effects of 1 percent technology and fiscal policy shocks
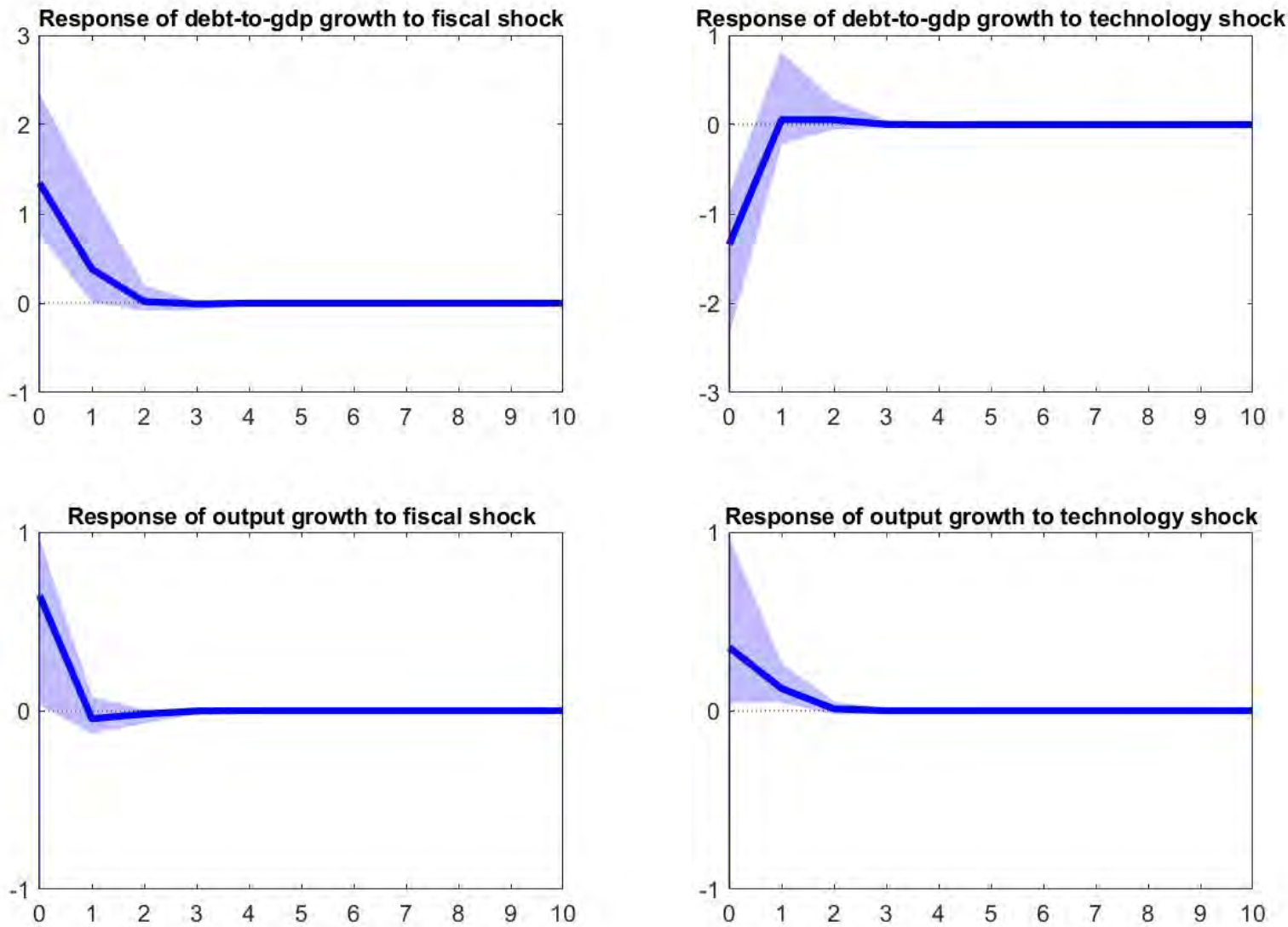
Figure S26: Posterior distributions of parameters $\alpha$ and $\beta$, and the effects of 1 percent technology and fiscal policy shocks for Norway

Posterior distributions of parameters $\alpha$ and $\beta$
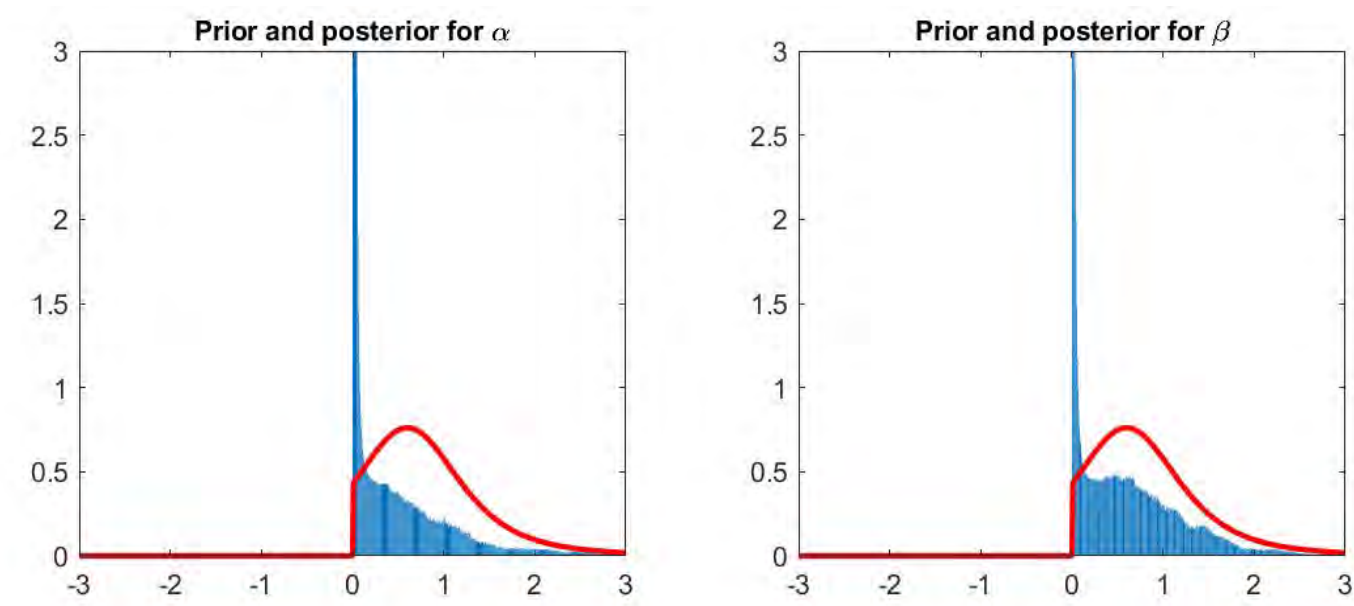

Posterior median (solid line) and 80 percent credible sets for the effects of 1 percent technology and fiscal policy shocks
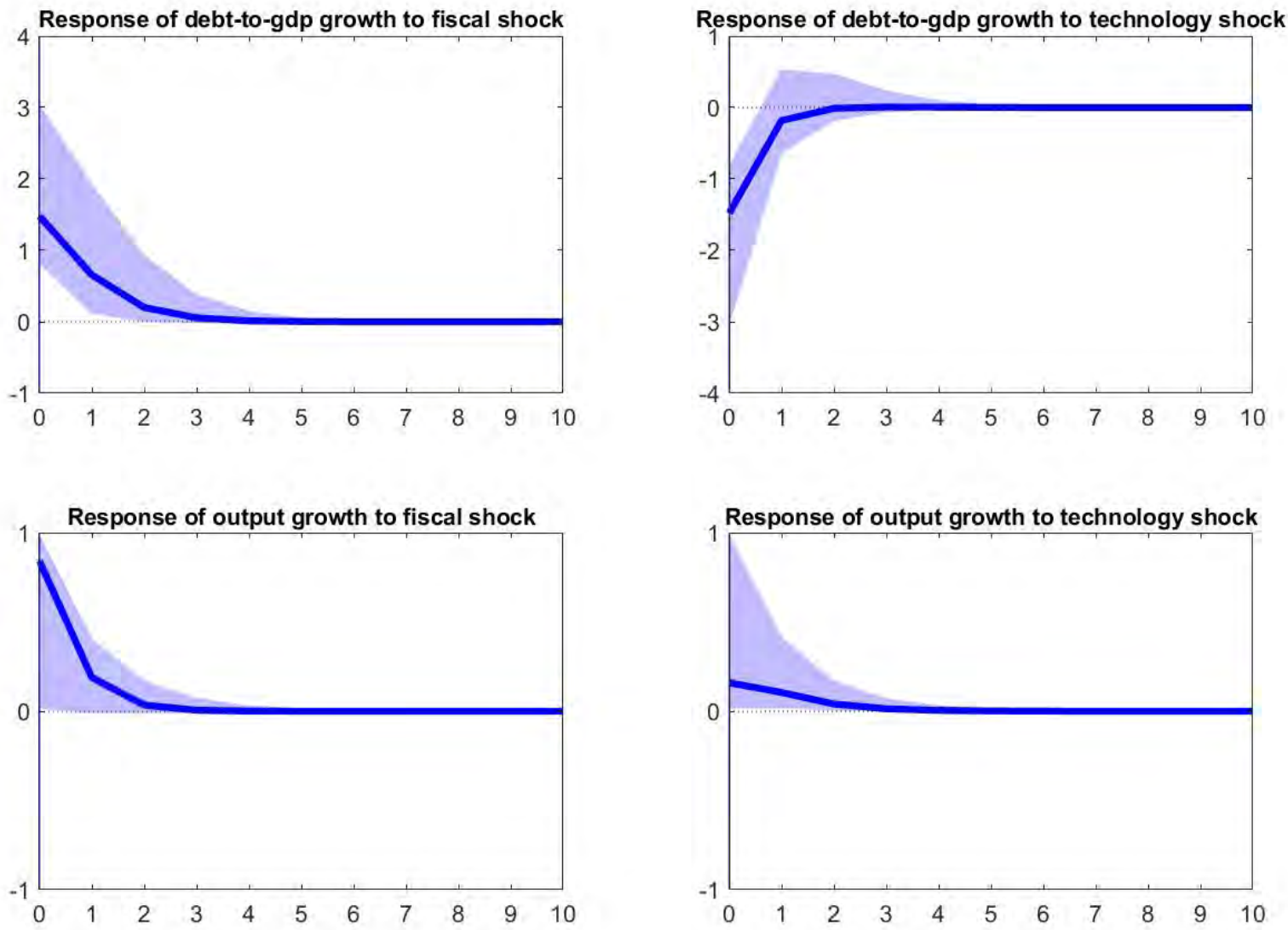
Figure S27: Posterior distributions of parameters $\alpha$ and $\beta$, and the effects of 1 percent technology and fiscal policy shocks for Peru

Posterior distributions of parameters $\alpha$ and $\beta$
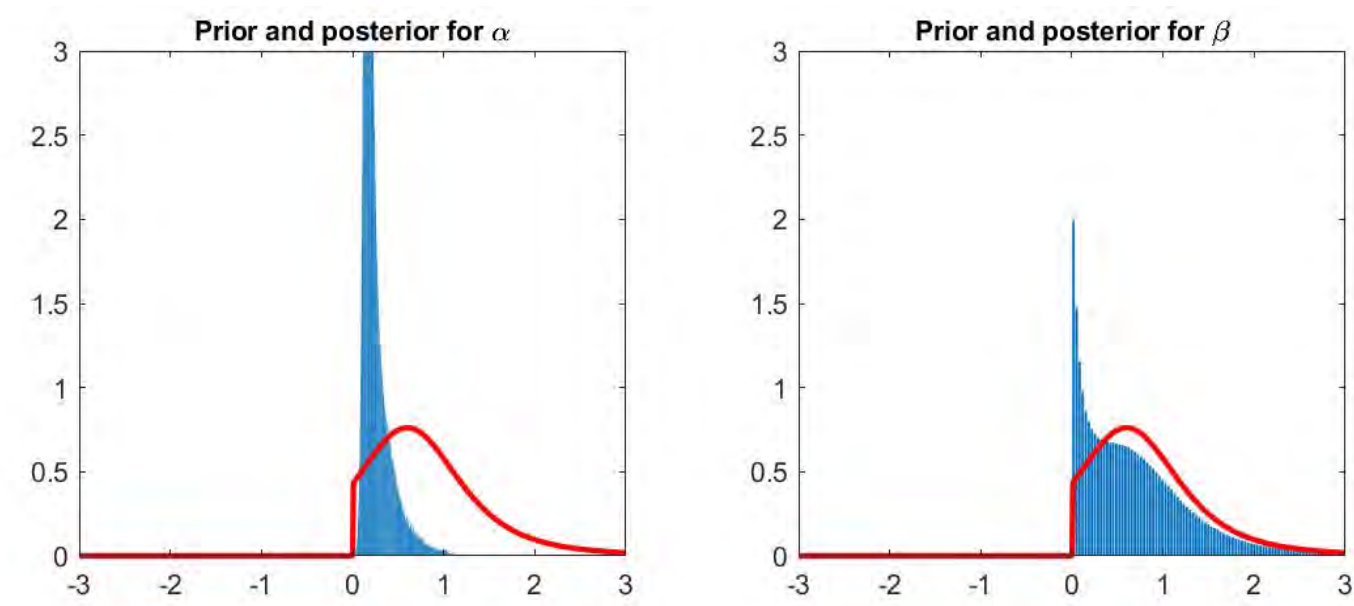

Posterior median (solid line) and 80 percent credible sets for the effects of 1 percent technology and fiscal policy shocks
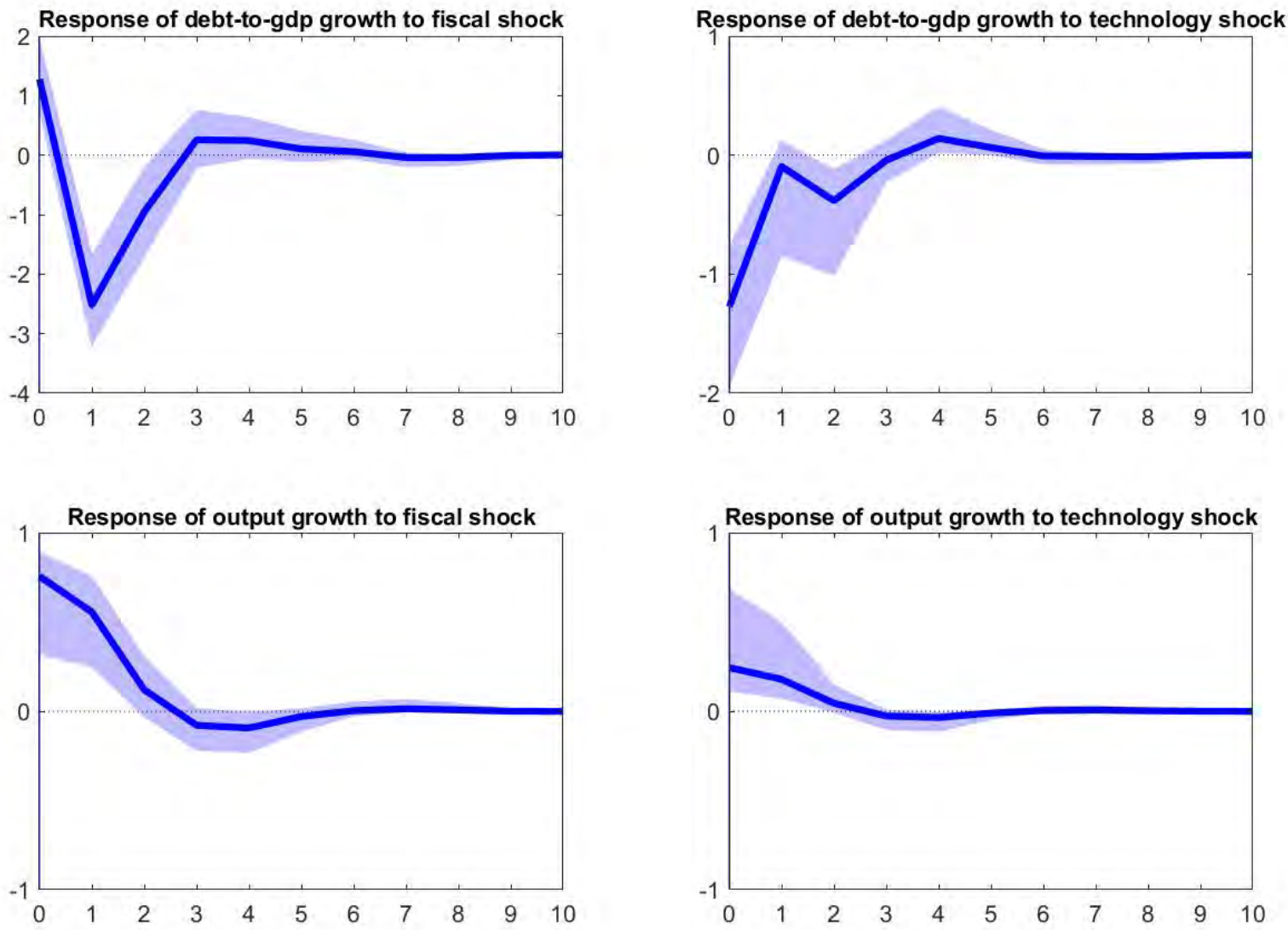
Figure S28: Posterior distributions of parameters $\alpha$ and $\beta$, and the effects of 1 percent technology and fiscal policy shocks for Philippines

Posterior distributions of parameters $\alpha$ and $\beta$
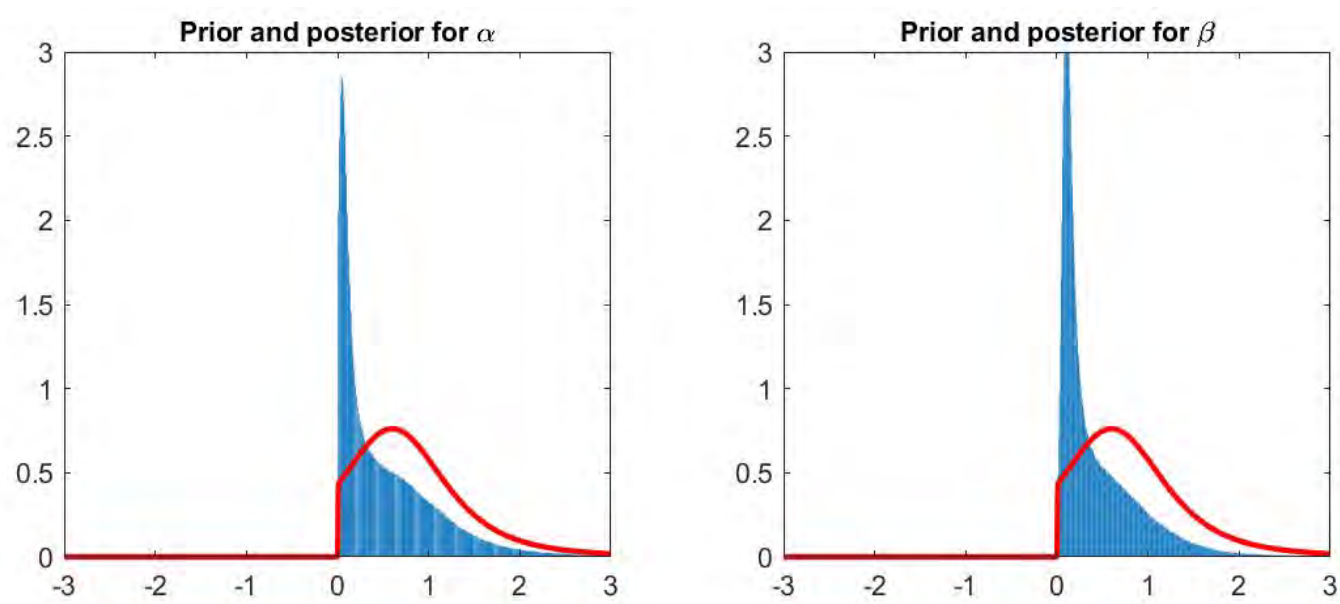

Posterior median (solid line) and 80 percent credible sets for the effects of 1 percent technology and fiscal policy shocks
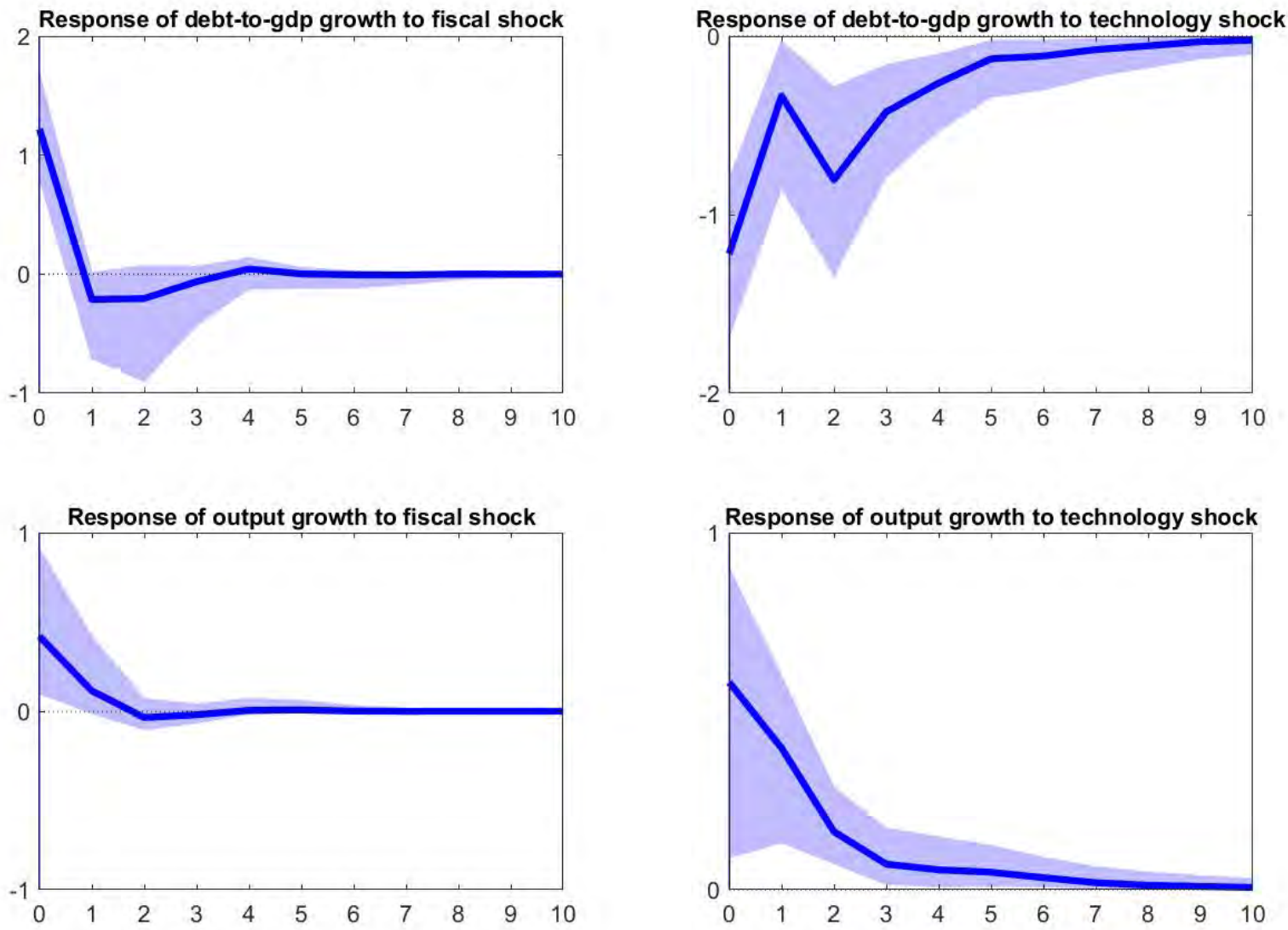
Figure S29: Posterior distributions of parameters $\alpha$ and $\beta$, and the effects of 1 percent technology and fiscal policy shocks for Singapore

Posterior distributions of parameters $\alpha$ and $\beta$
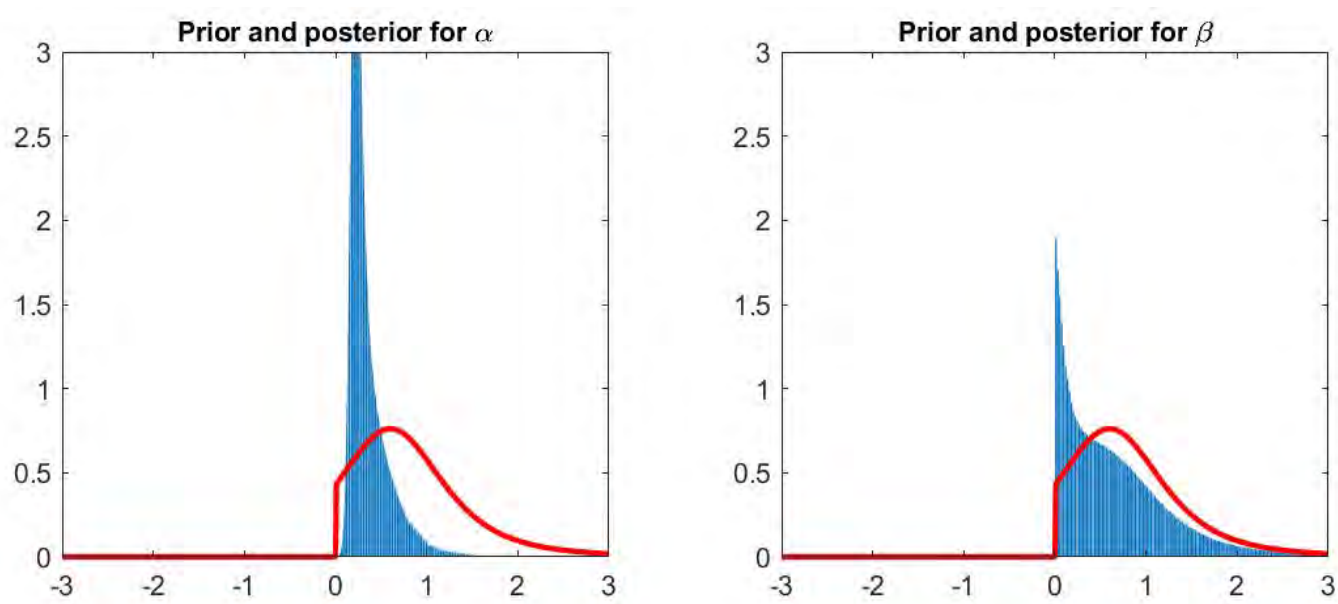

Posterior median (solid line) and 80 percent credible sets for the effects of 1 percent technology and fiscal policy shocks
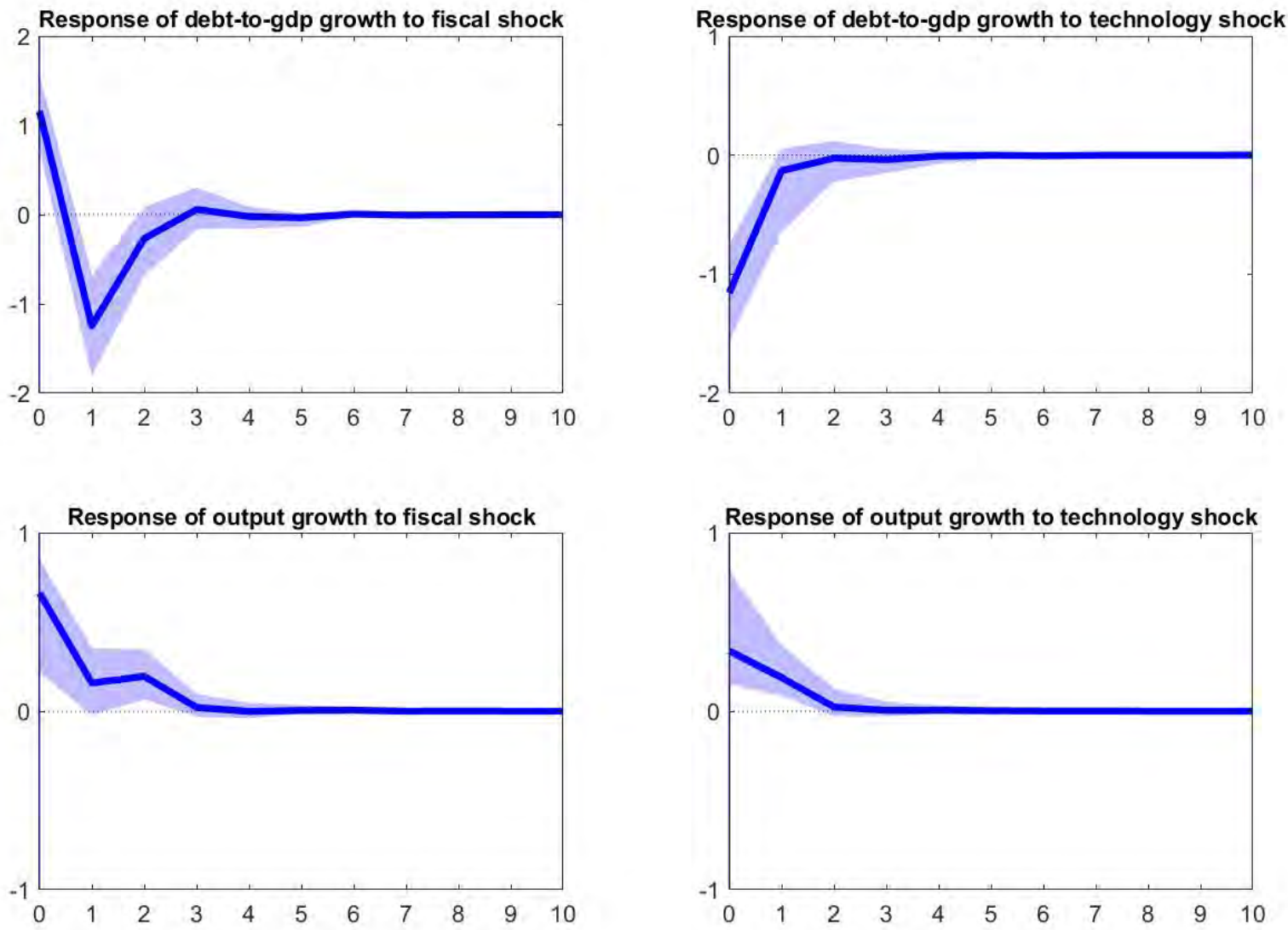
Figure S30: Posterior distributions of parameters $\alpha$ and $\beta$, and the effects of 1 percent technology and fiscal policy shocks for South Africa

Posterior distributions of parameters $\alpha$ and $\beta$
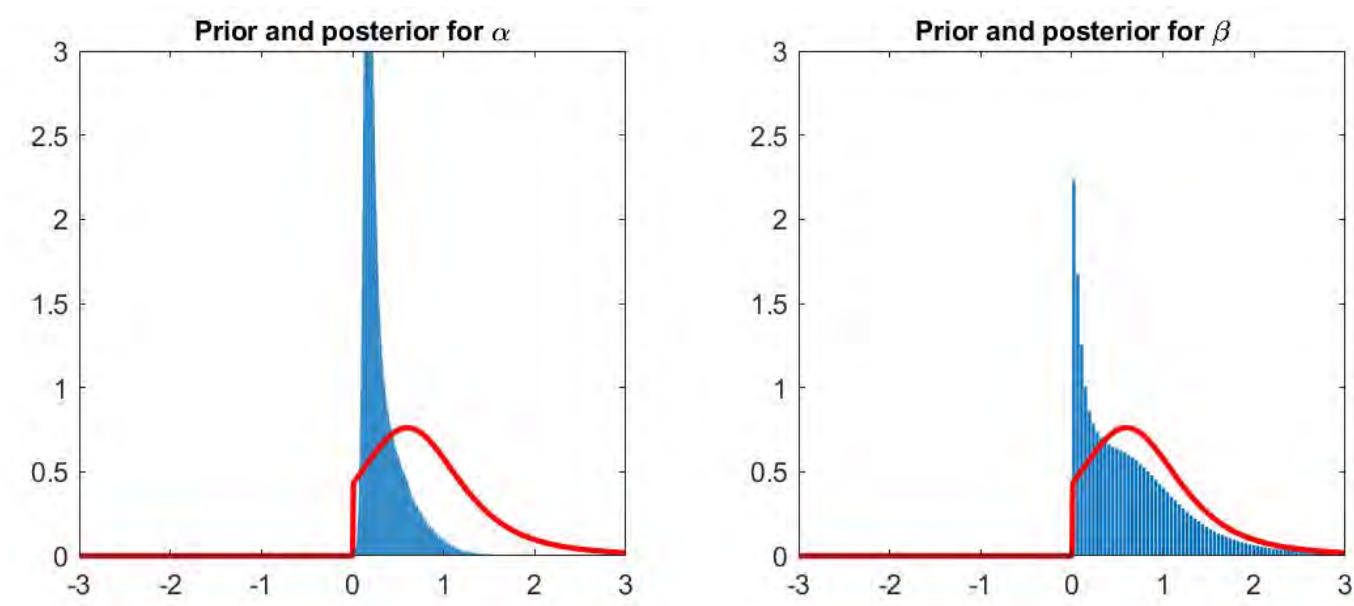

Posterior median (solid line) and 80 percent credible sets for the effects of 1 percent technology and fiscal policy shocks
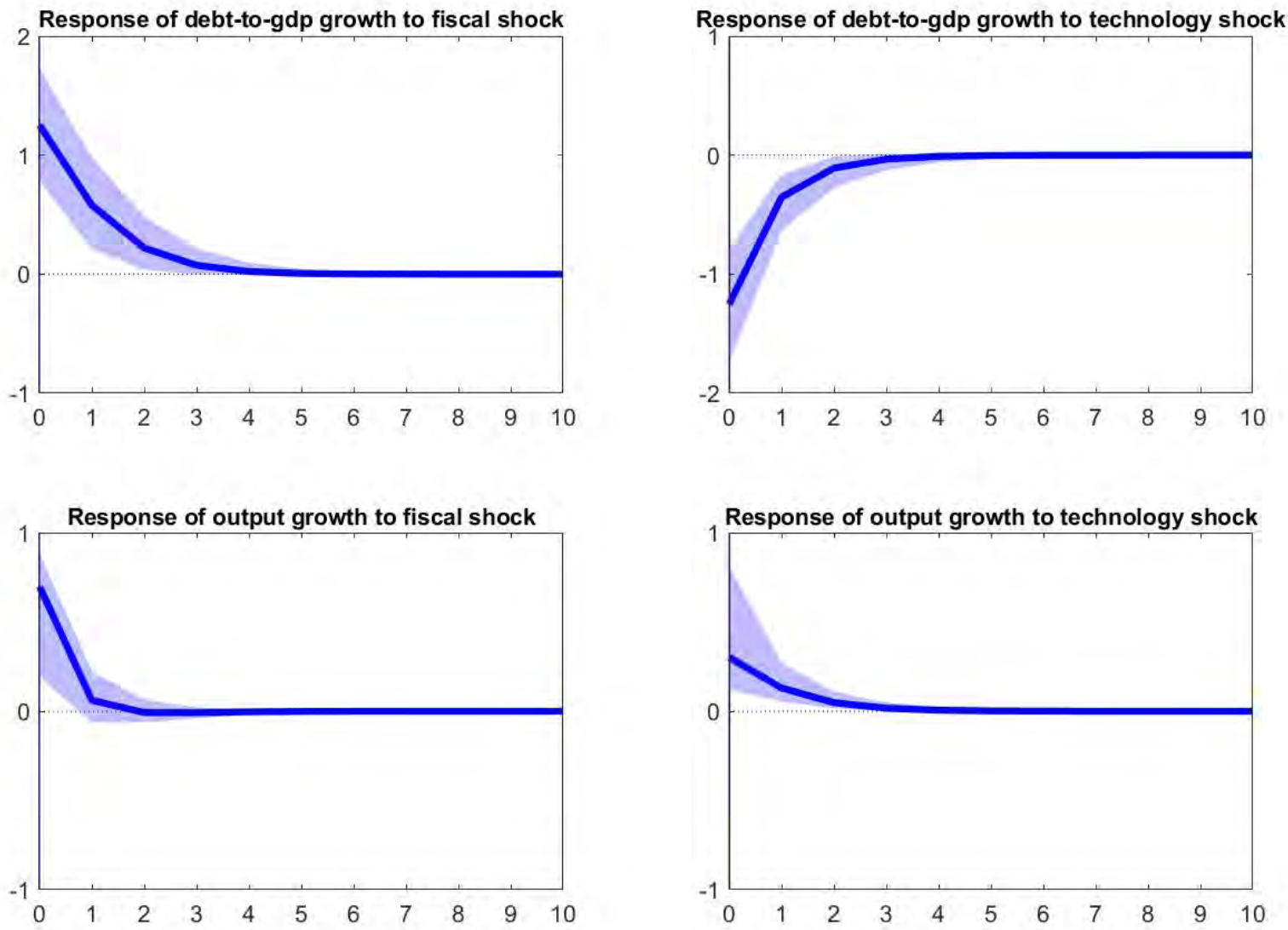
Figure S31: Posterior distributions of parameters $\alpha$ and $\beta$, and the effects of 1 percent technology and fiscal policy shocks for Spain

Posterior distributions of parameters $\alpha$ and $\beta$
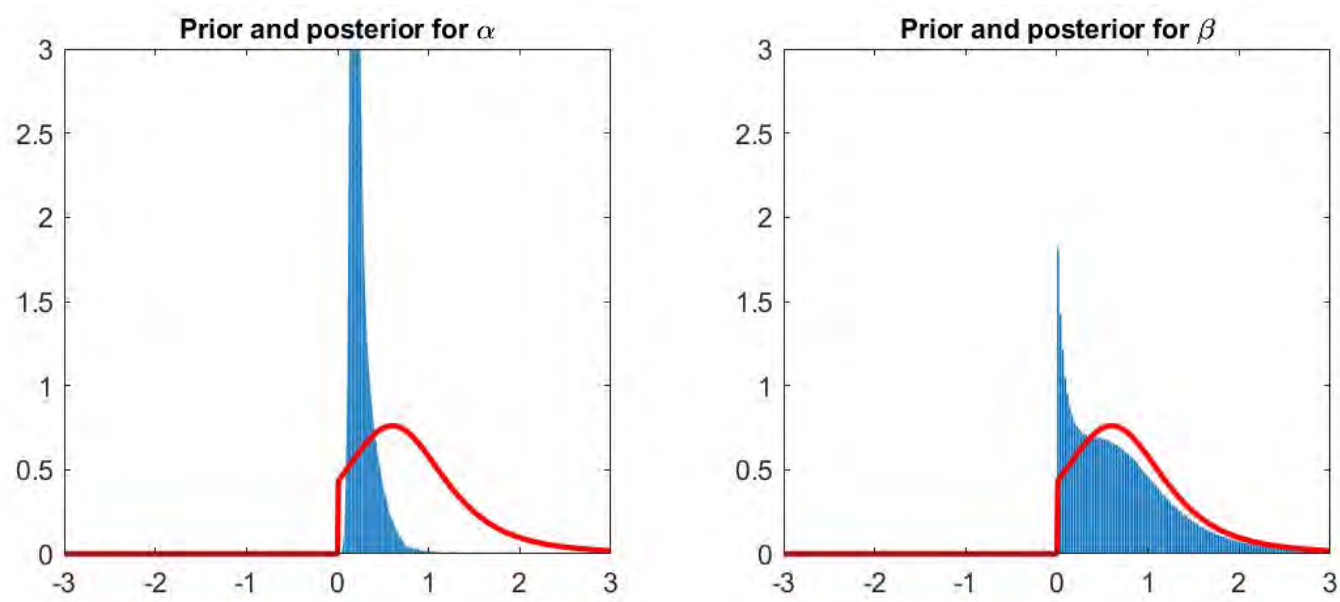

Posterior median (solid line) and 80 percent credible sets for the effects of 1 percent technology and fiscal policy shocks
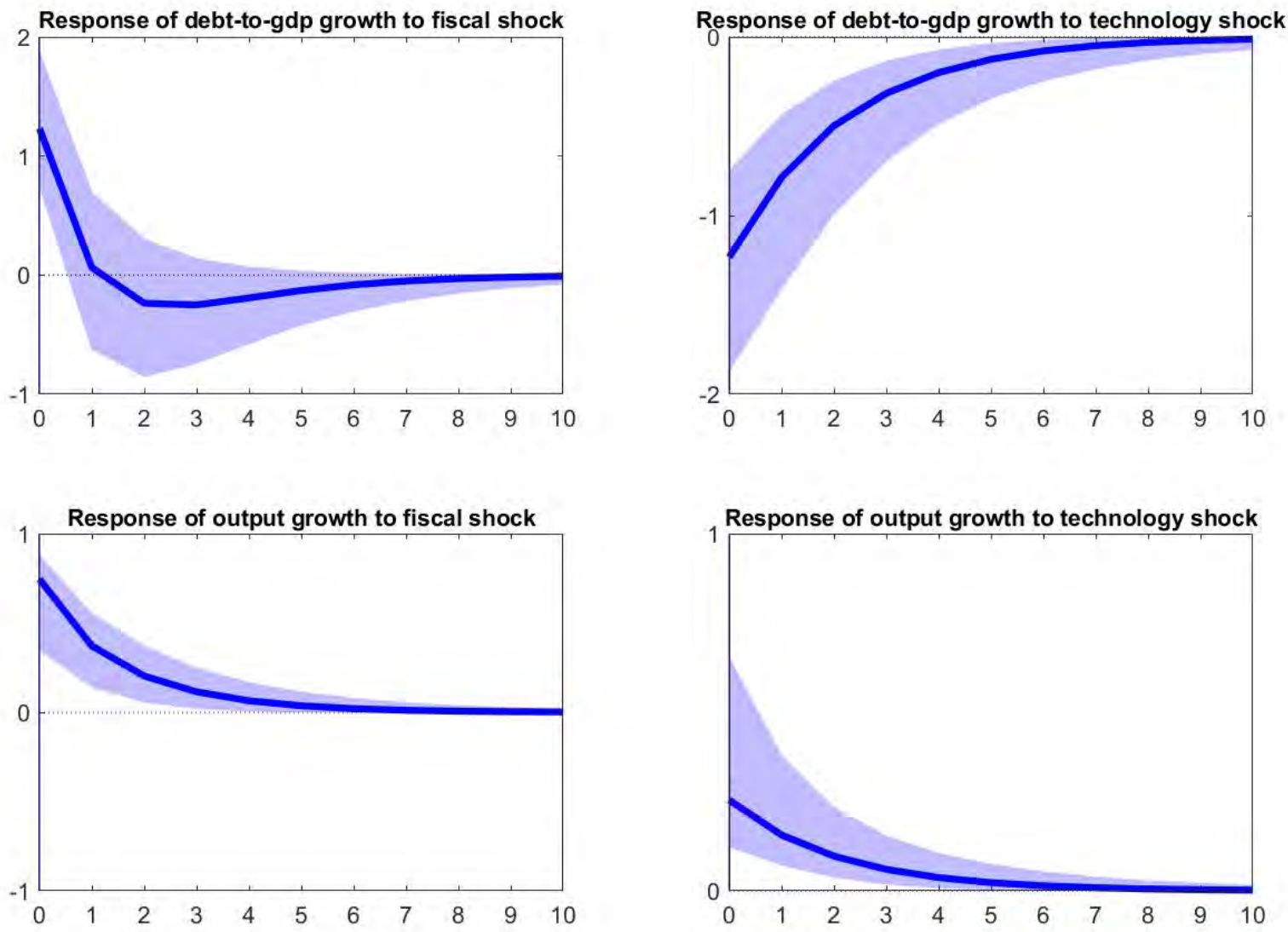
Figure S32: Posterior distributions of parameters $\alpha$ and $\beta$, and the effects of 1 percent technology and fiscal policy shocks for Sweden

Posterior distributions of parameters $\alpha$ and $\beta$
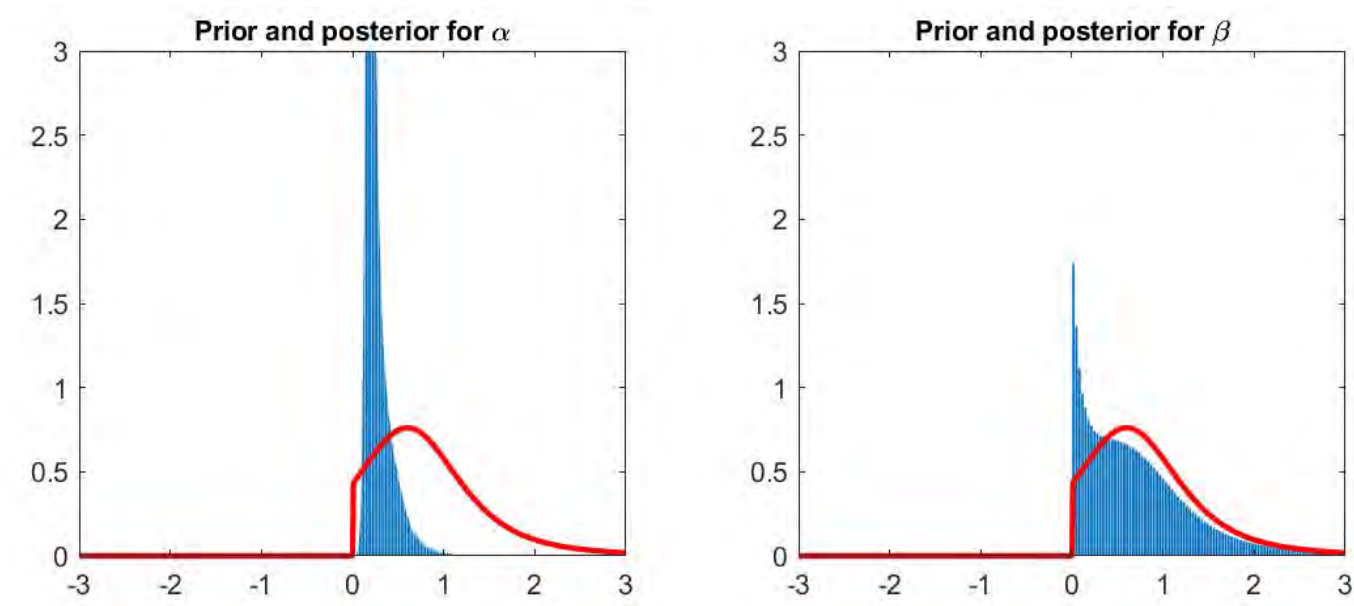

Posterior median (solid line) and 80 percent credible sets for the effects of 1 percent technology and fiscal policy shocks
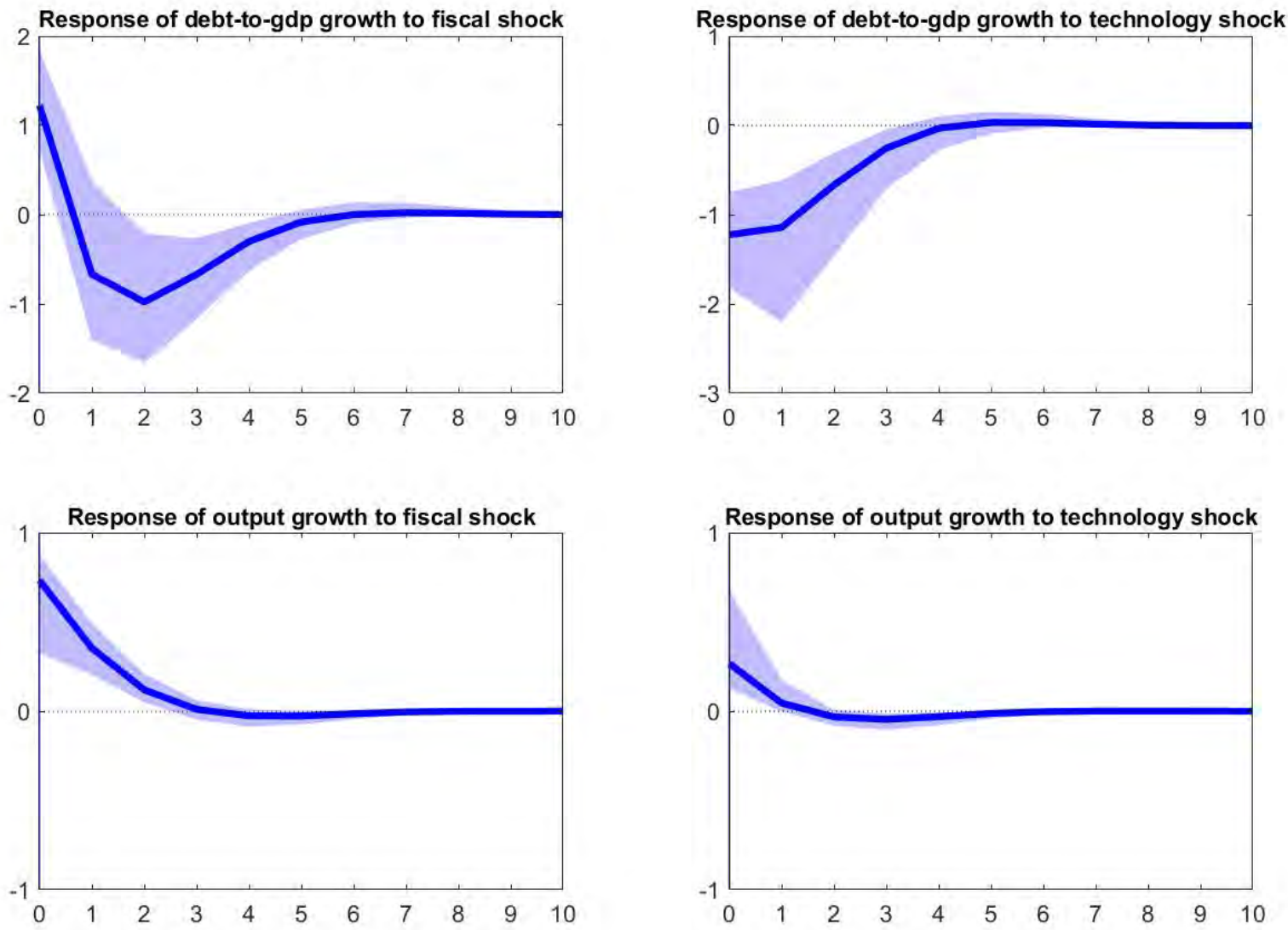
Figure S33: Posterior distributions of parameters $\alpha$ and $\beta$, and the effects of 1 percent technology and fiscal policy shocks for Switzerland

Posterior distributions of parameters $\alpha$ and $\beta$
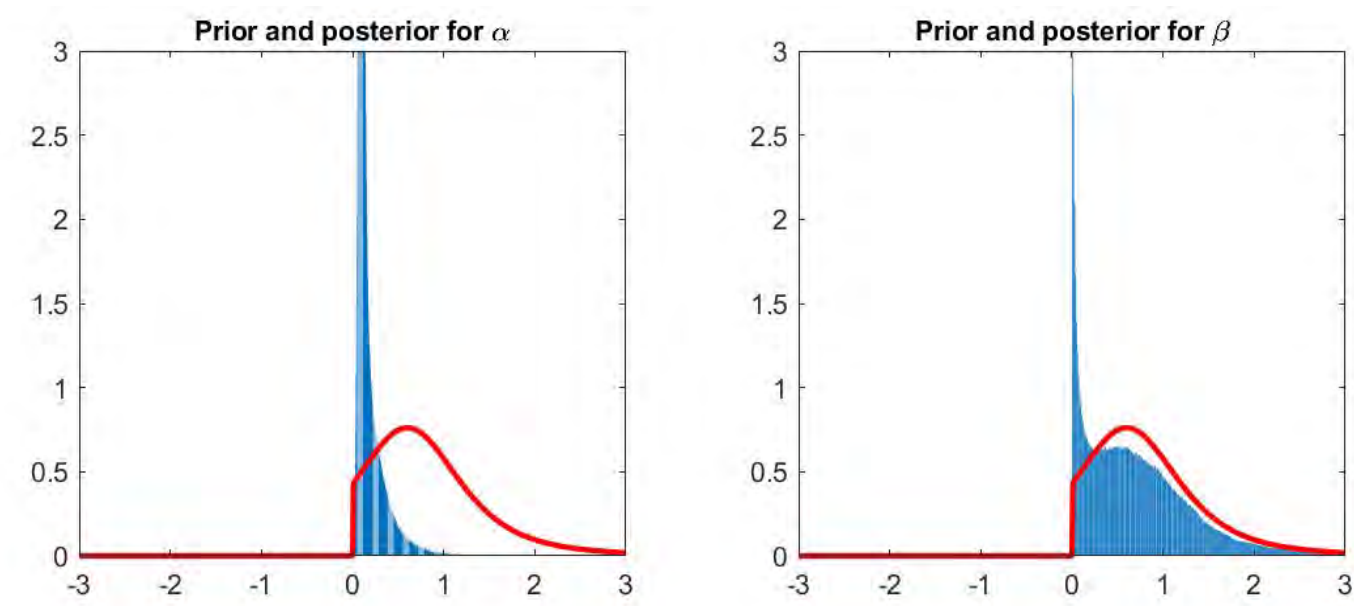

Posterior median (solid line) and 80 percent credible sets for the effects of 1 percent technology and fiscal policy shocks
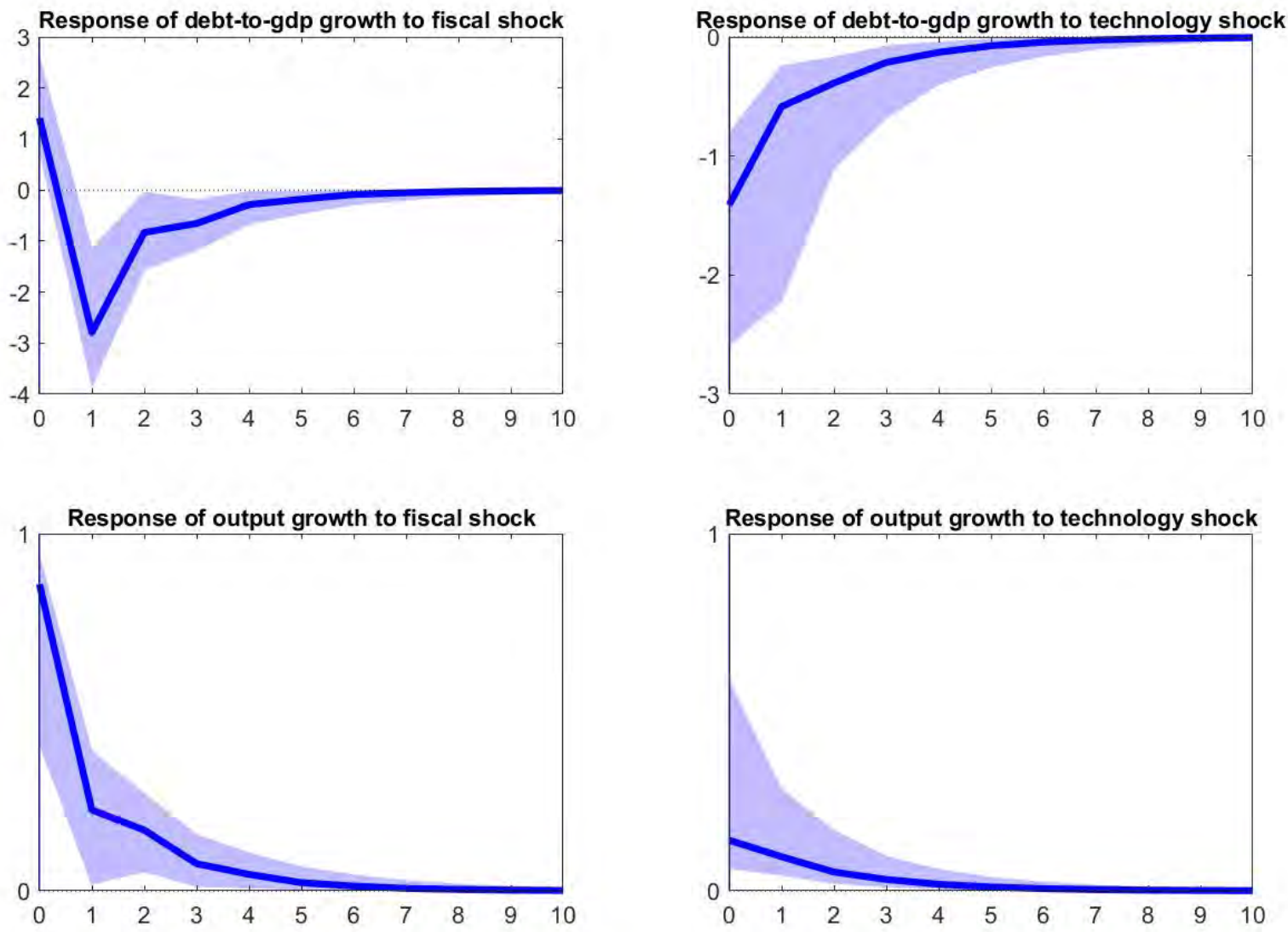
Figure S34: Posterior distributions of parameters $\alpha$ and $\beta$, and the effects of 1 percent technology and fiscal policy shocks for Thailand

Posterior distributions of parameters $\alpha$ and $\beta$
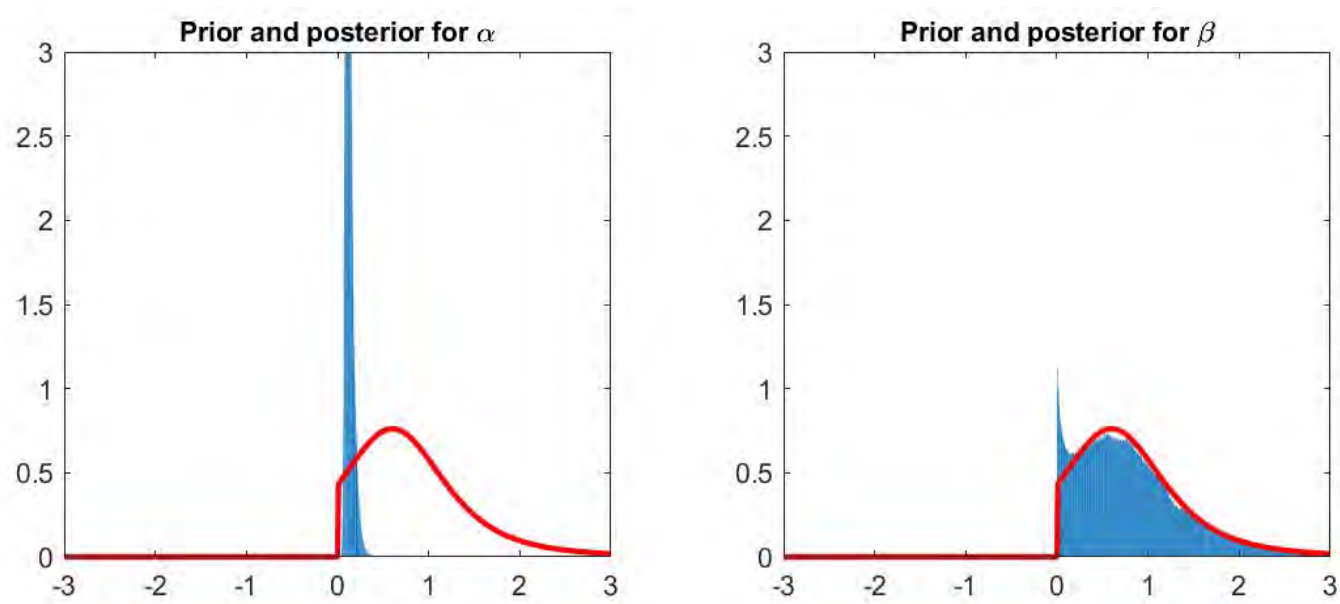

Posterior median (solid line) and 80 percent credible sets for the effects of 1 percent technology and fiscal policy shocks
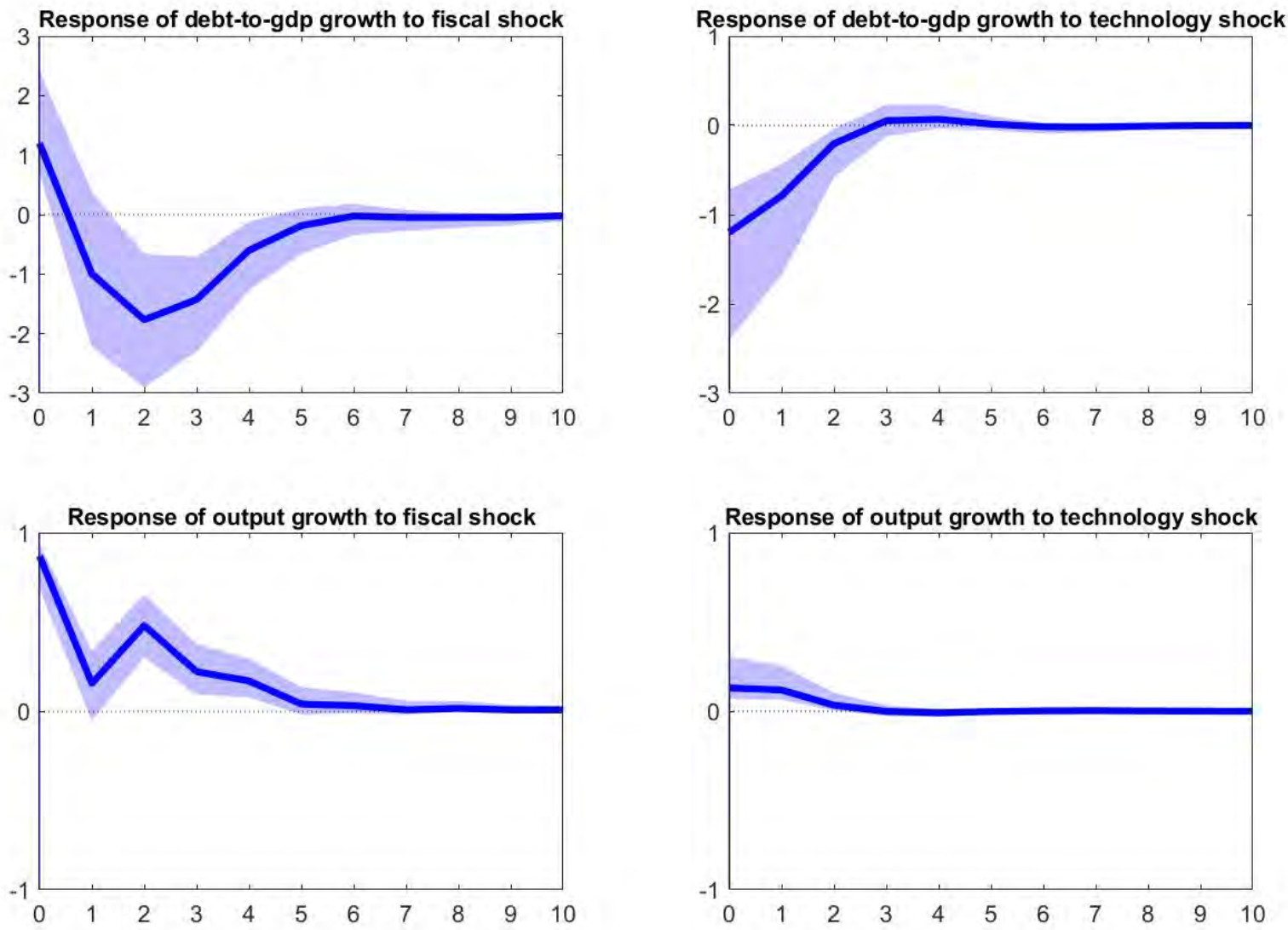
Figure S35: Posterior distributions of parameters $\alpha$ and $\beta$, and the effects of 1 percent technology and fiscal policy shocks for Tunisia

Posterior distributions of parameters $\alpha$ and $\beta$
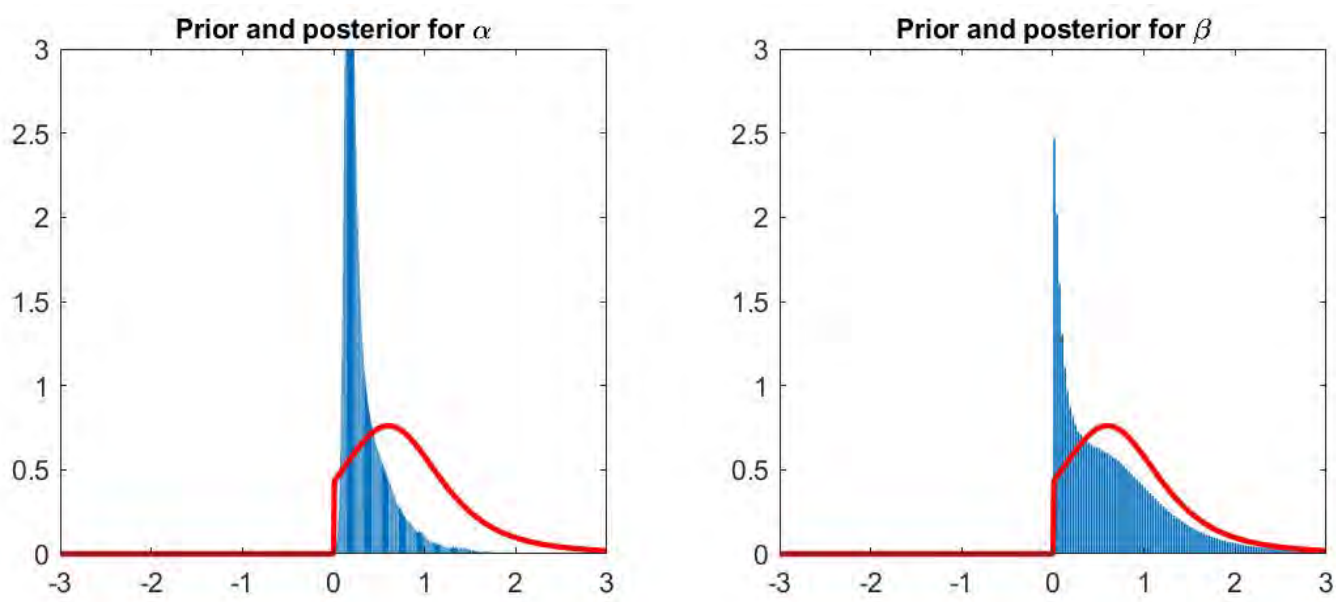

Posterior median (solid line) and 80 percent credible sets for the effects of 1 percent technology and fiscal policy shocks
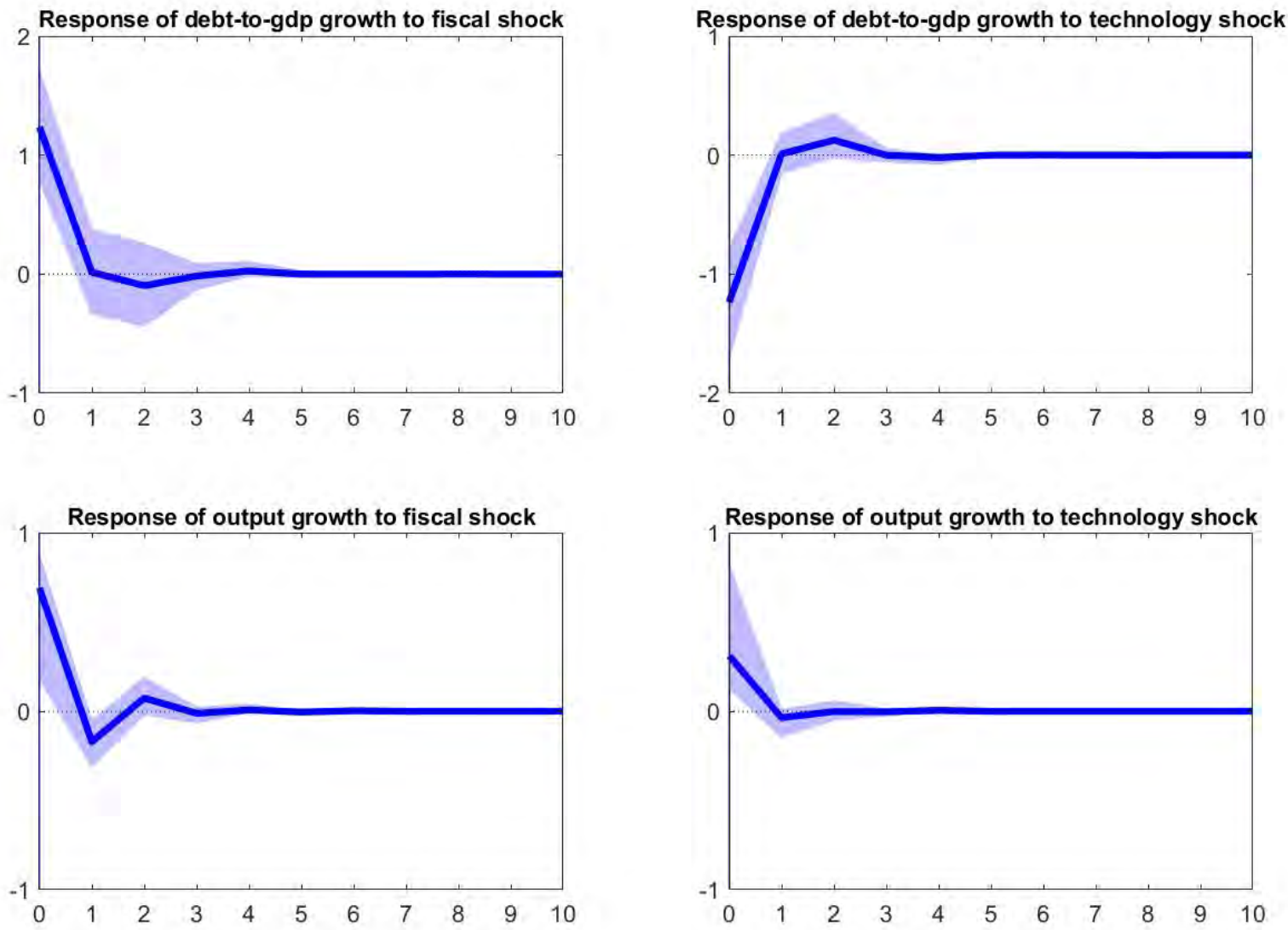
Figure S36: Posterior distributions of parameters $\alpha$ and $\beta$, and the effects of 1 percent technology and fiscal policy shocks for Turkey

Posterior distributions of parameters $\alpha$ and $\beta$
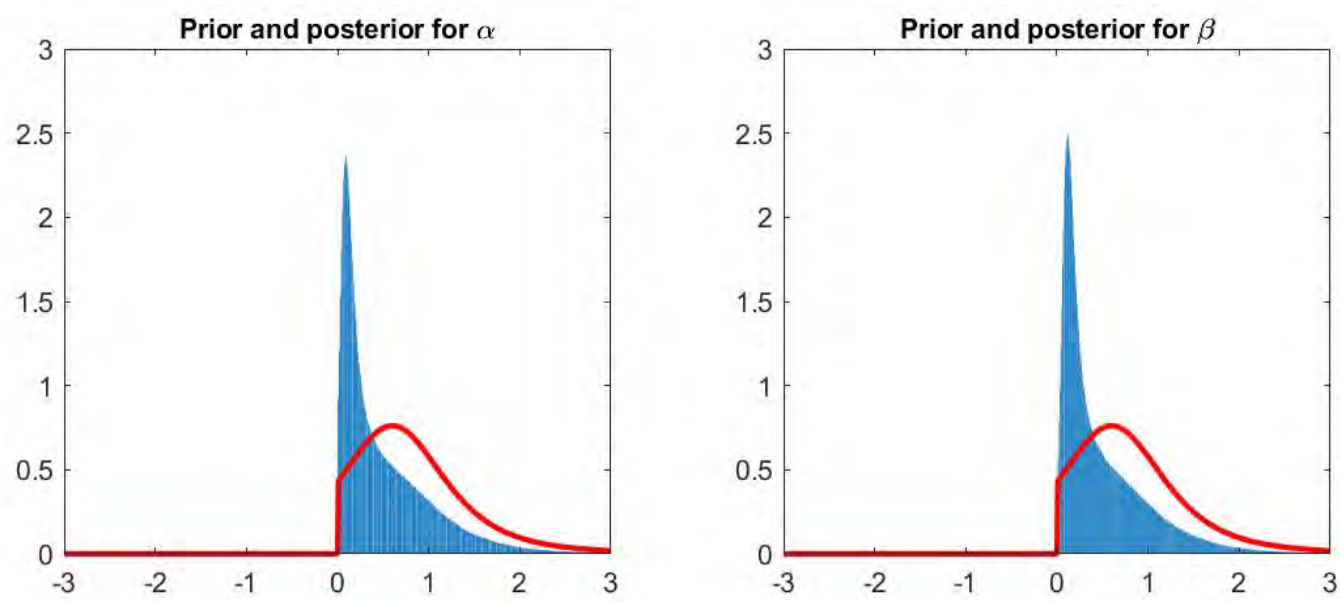

Posterior median (solid line) and 80 percent credible sets for the effects of 1 percent technology and fiscal policy shocks
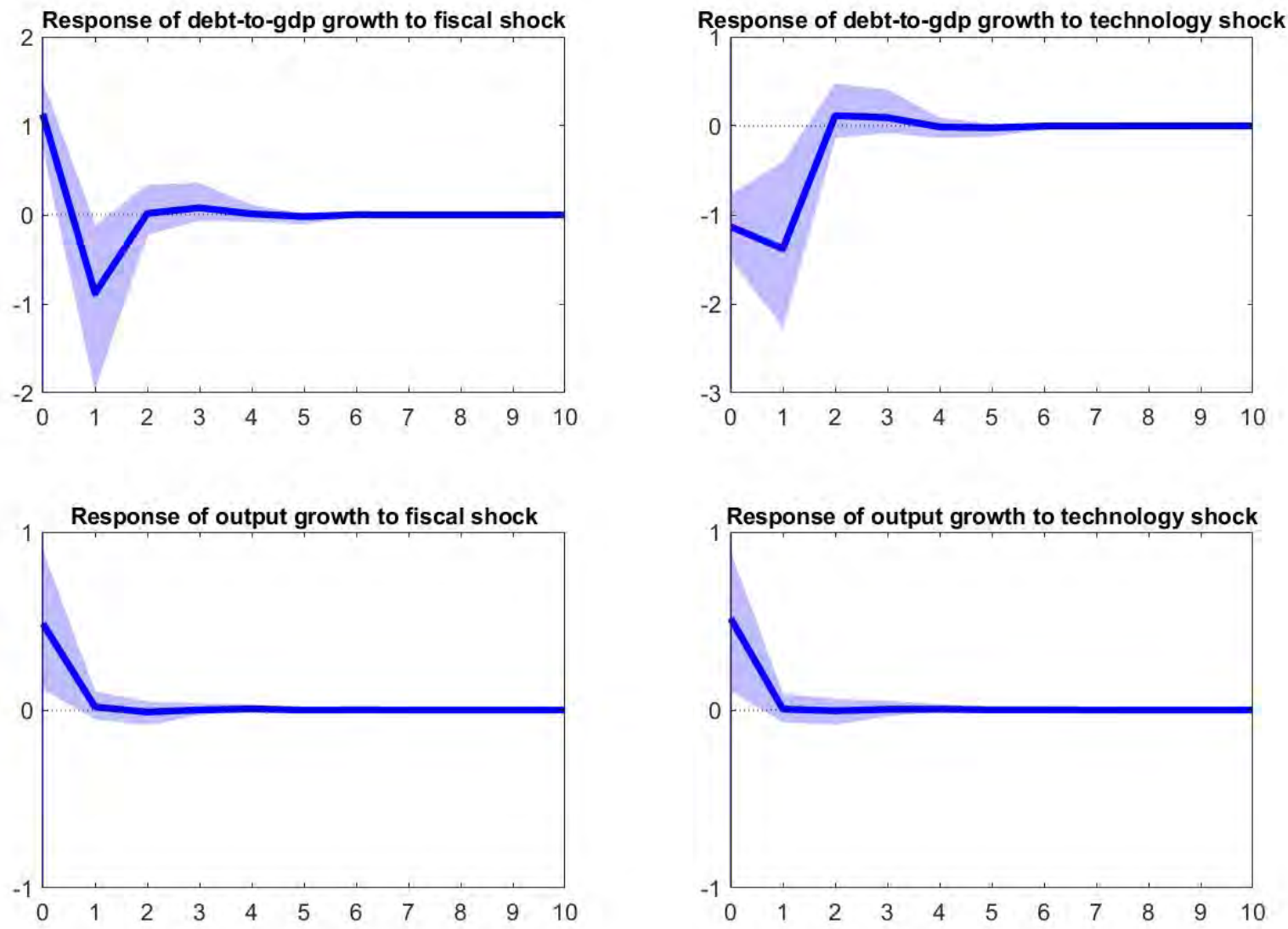
Figure S37: Posterior distributions of parameters $\alpha$ and $\beta$, and the effects of 1 percent technology and fiscal policy shocks for UK

Posterior distributions of parameters $\alpha$ and $\beta$
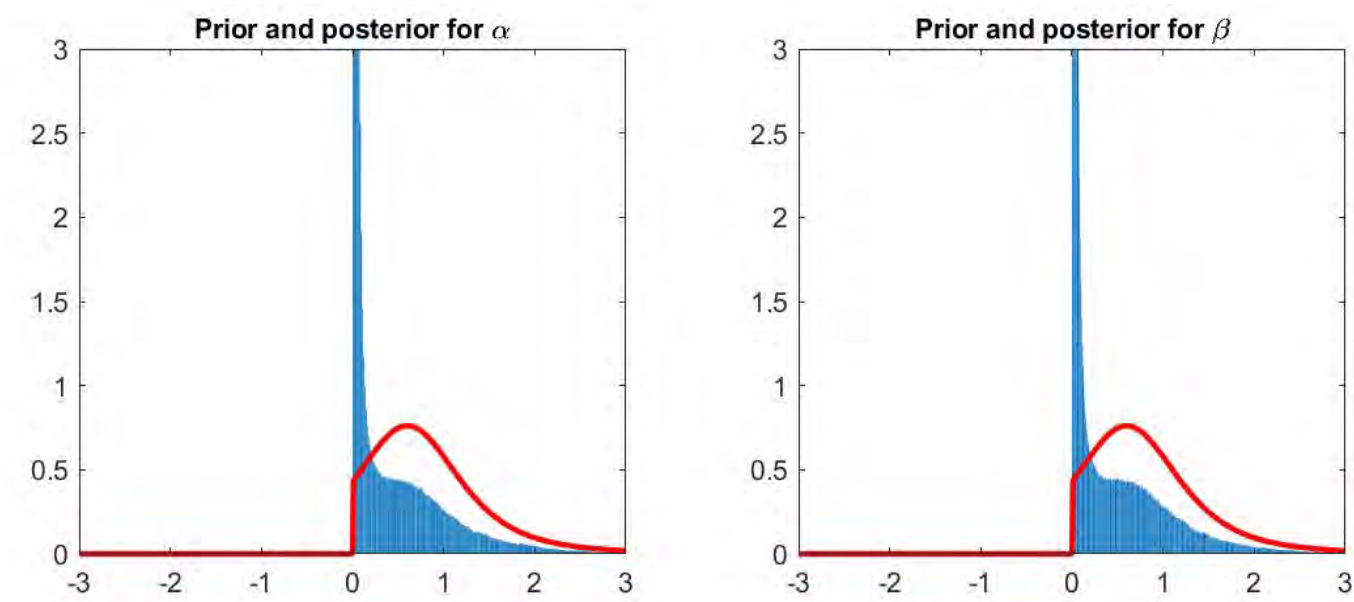

Posterior median (solid line) and 80 percent credible sets for the effects of 1 percent technology and fiscal policy shocks
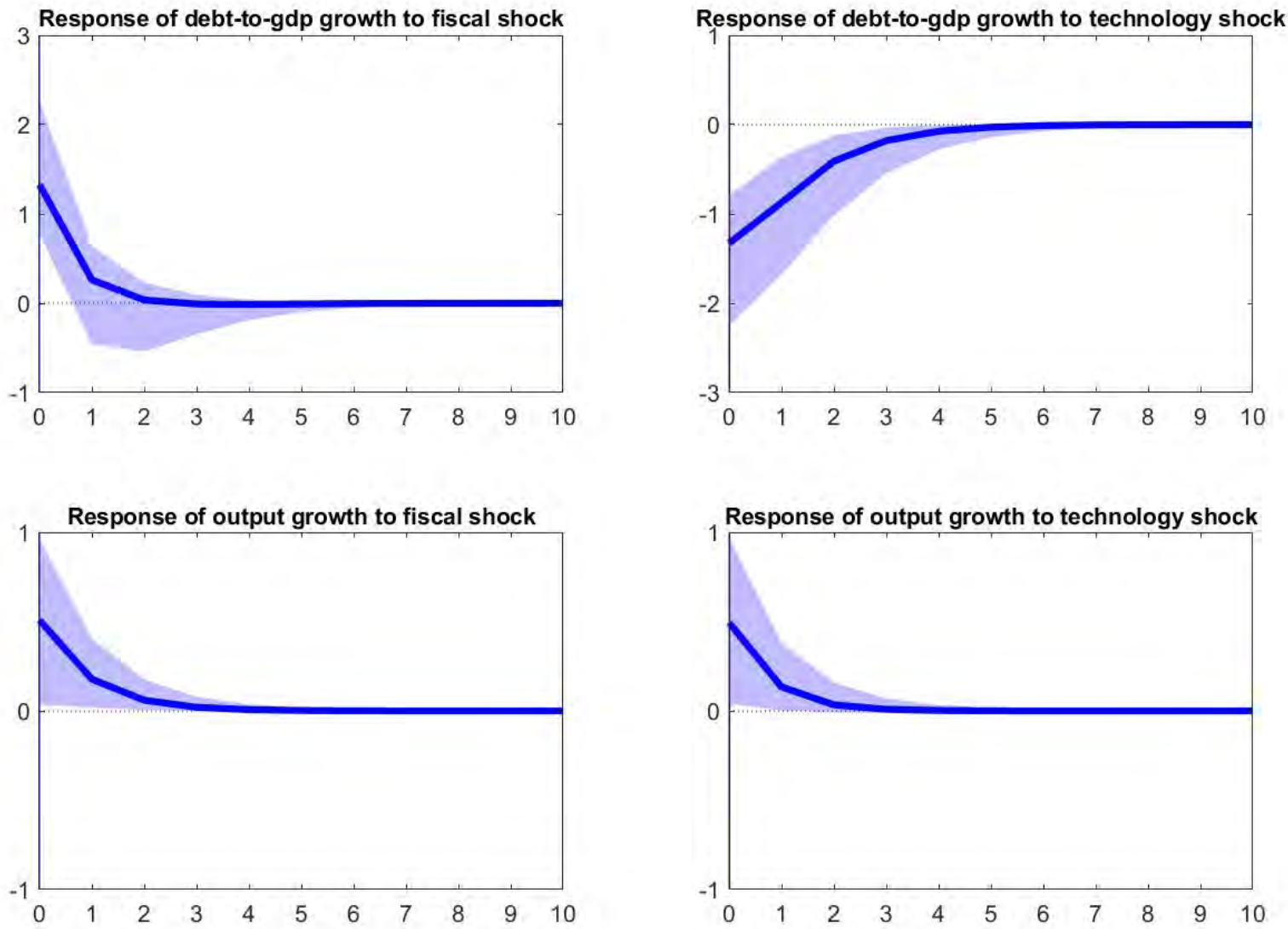
Figure S38: Posterior distributions of parameters $\alpha$ and $\beta$, and the effects of 1 percent technology and fiscal policy shocks for USA

Posterior distributions of parameters $\alpha$ and $\beta$
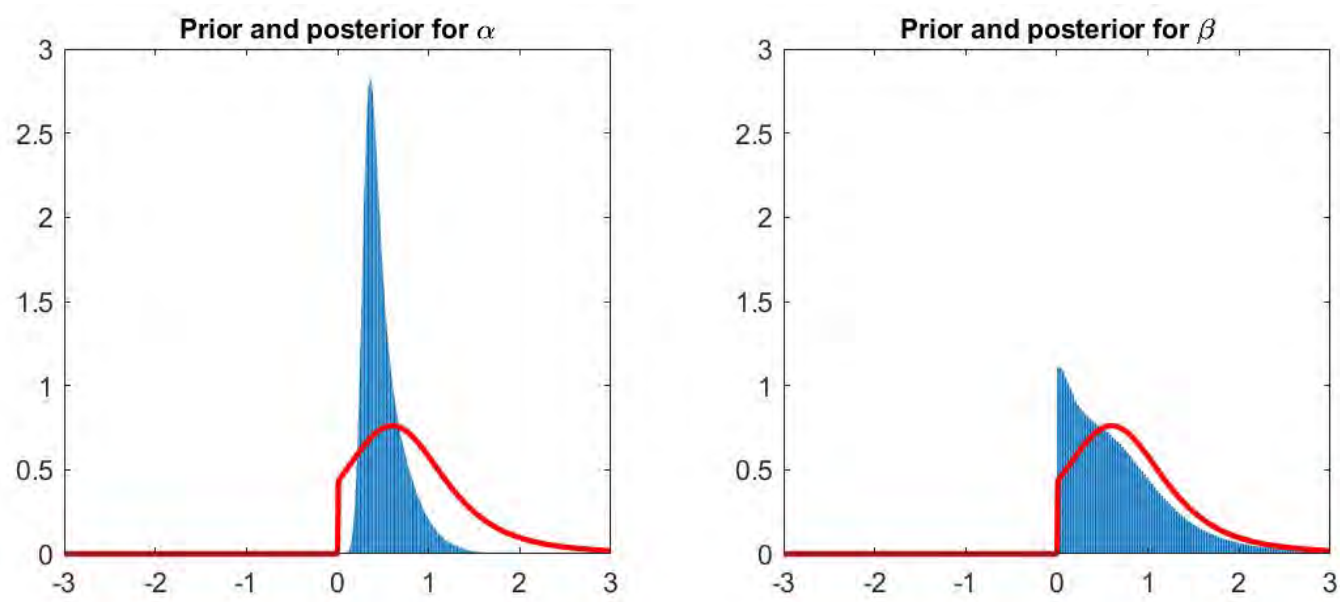

Posterior median (solid line) and 80 percent credible sets for the effects of 1 percent technology and fiscal policy shocks
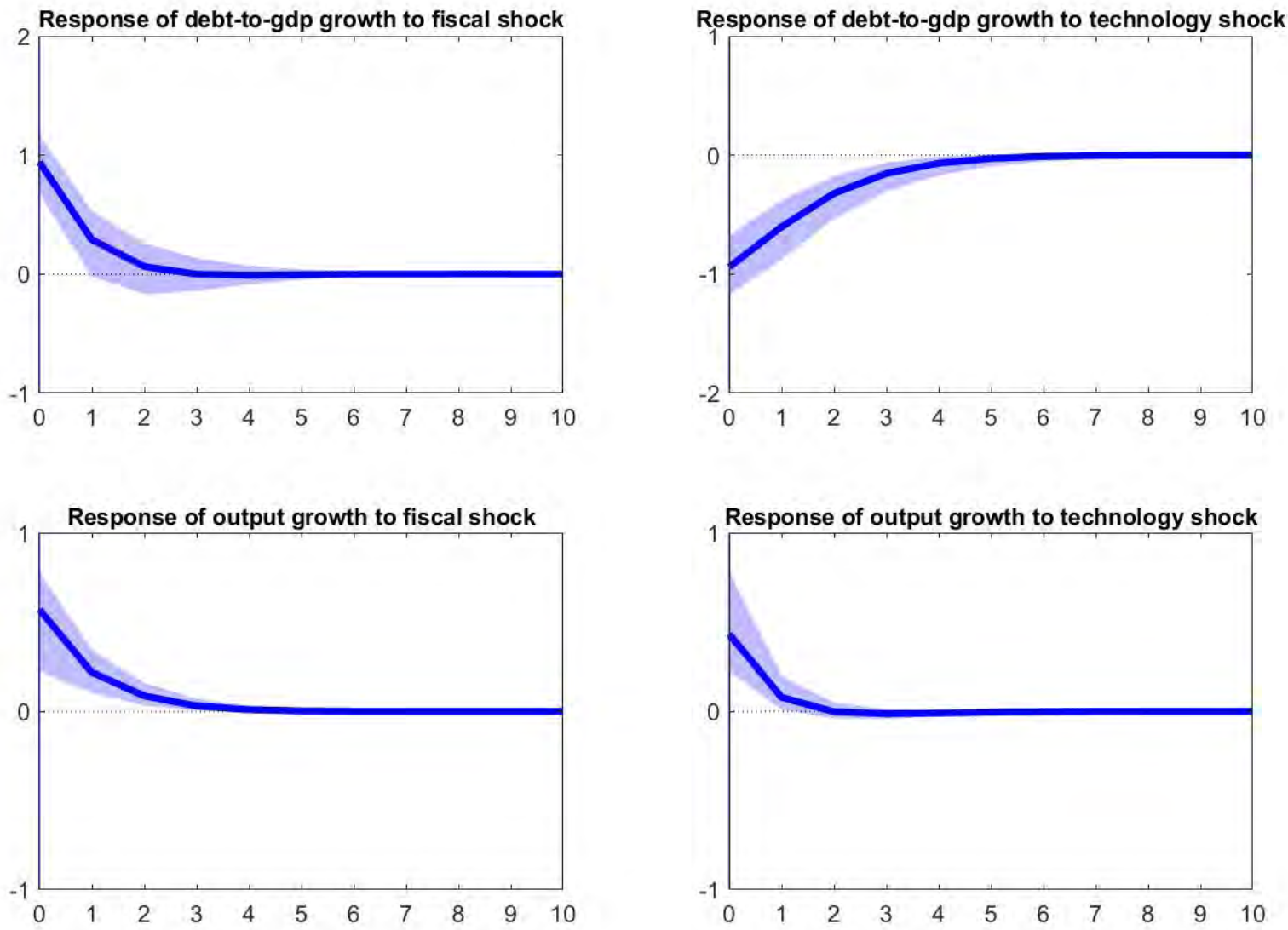
Figure S39: Posterior distributions of parameters $\alpha$ and $\beta$, and the effects of 1 percent technology and fiscal policy shocks for Venezuela

Posterior distributions of parameters $\alpha$ and $\beta$
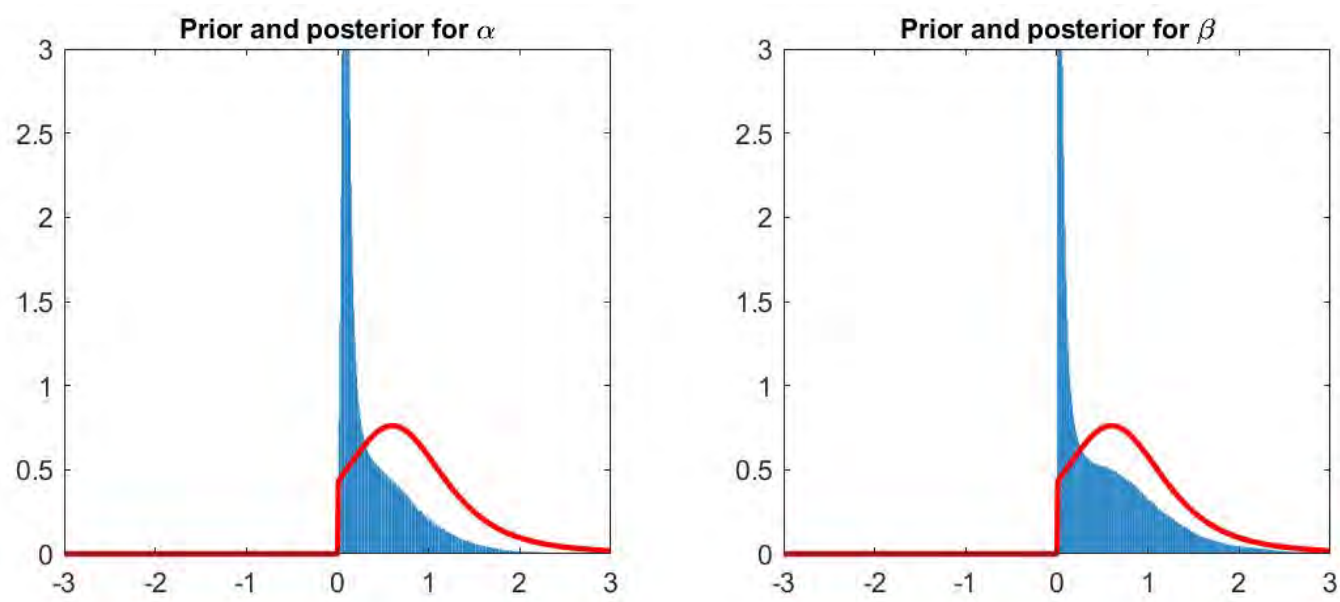

Posterior median (solid line) and 80 percent credible sets for the effects of 1 percent technology and fiscal policy shocks
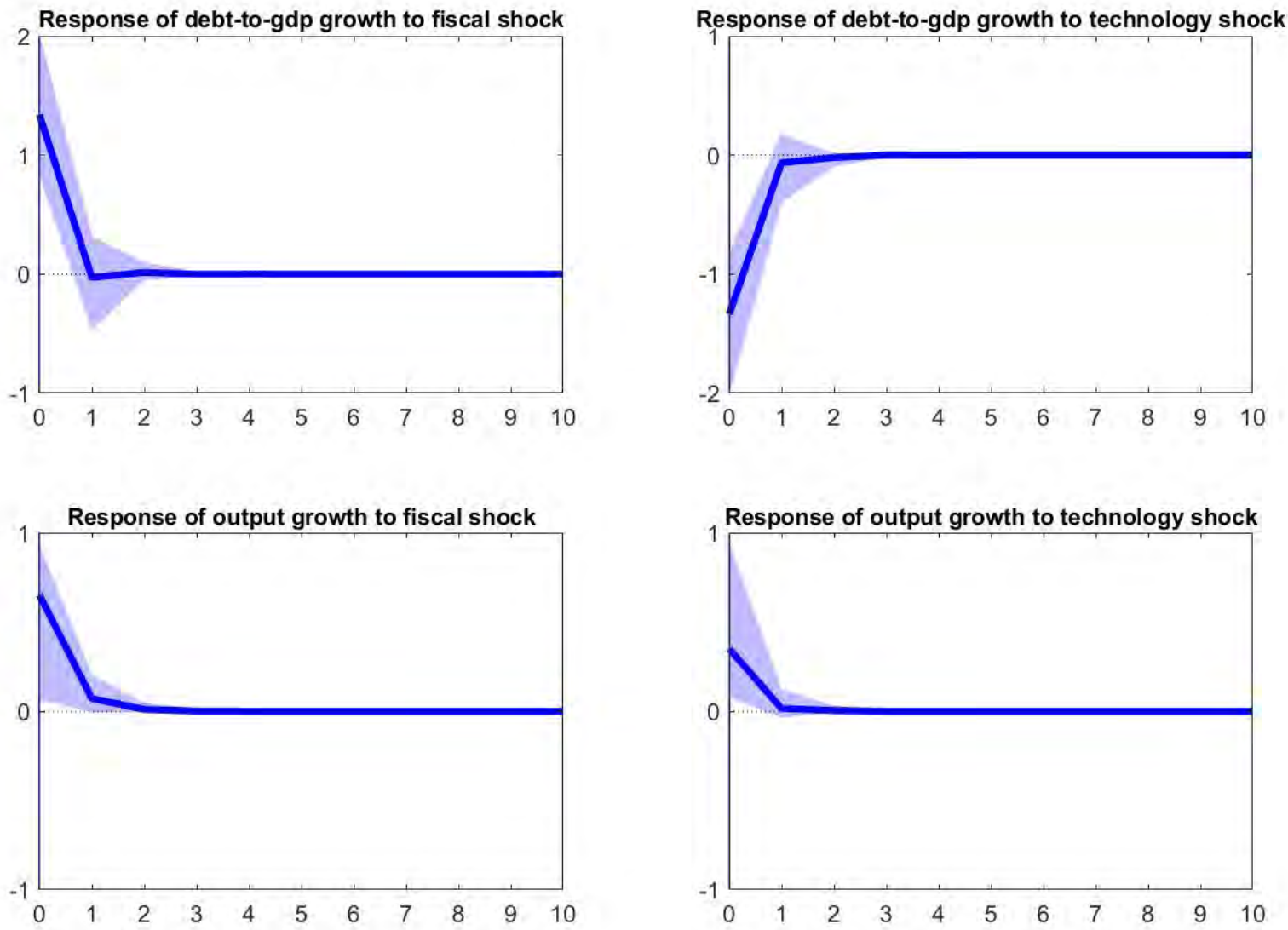
S2 Effects of national technology and fiscal policy shocks in models with and without global shocks

Figure S40: IRFs for Argentina in models with and without global shocks (median of posterior distribution)

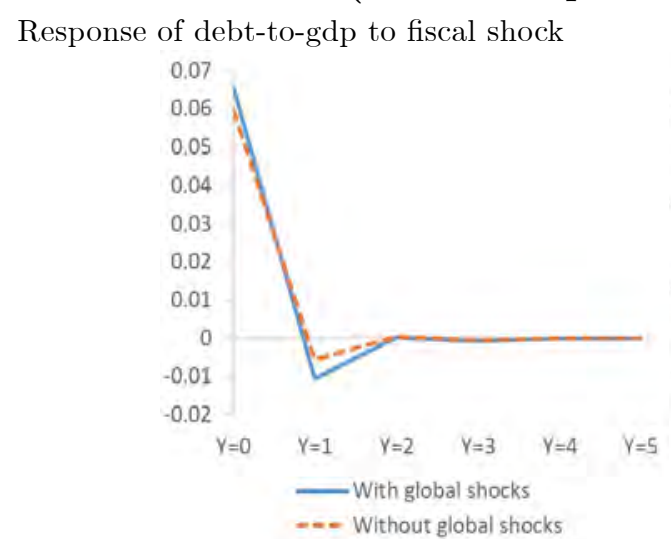

Response of debt-to-gdp to technology shock

Response of output to fiscal shock
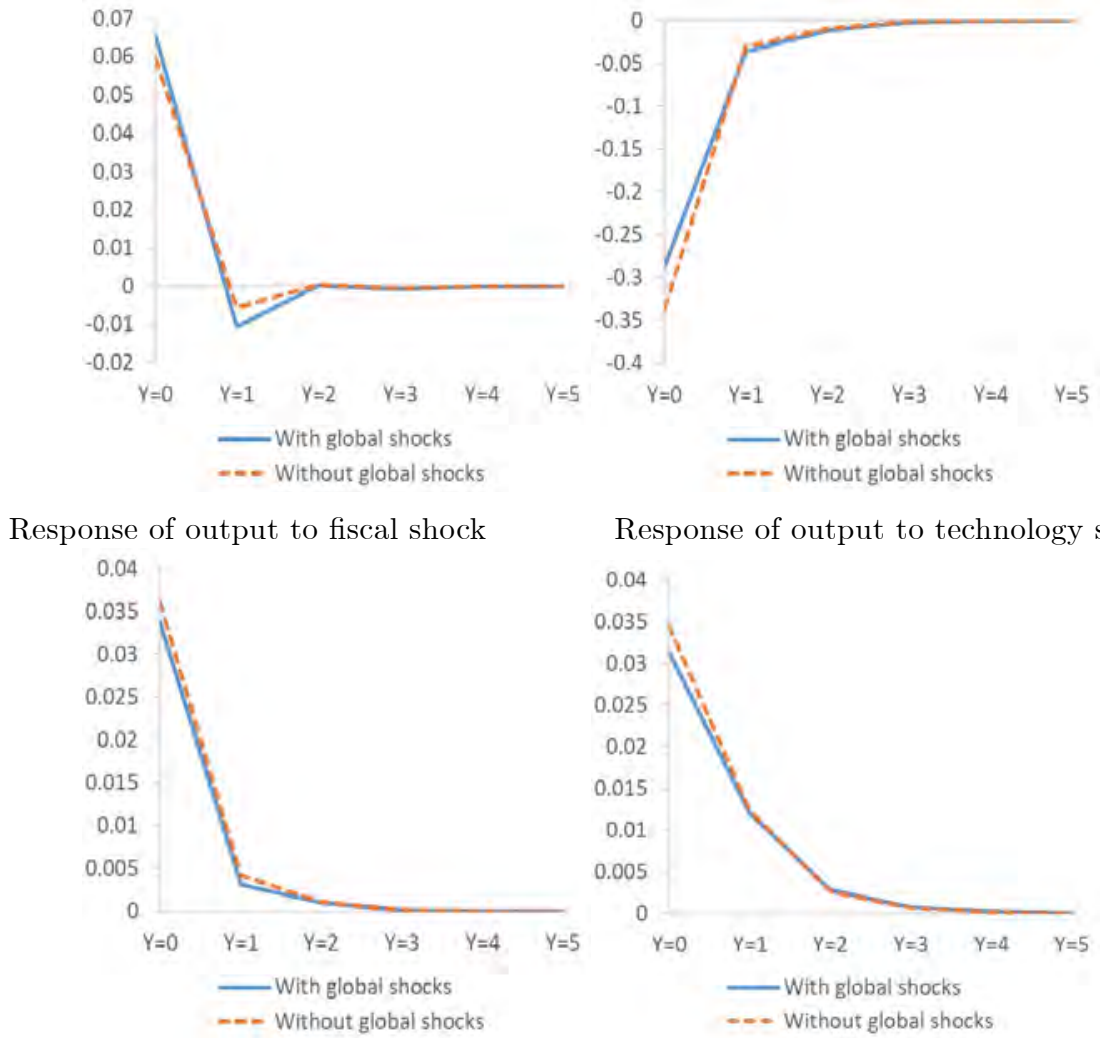

Response of output to technology shock

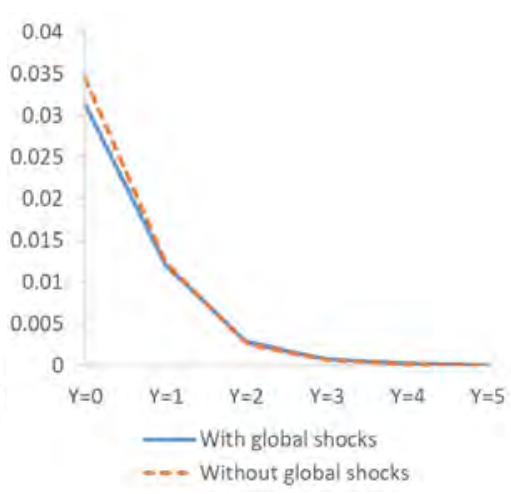


Figure S41: IRFs for Australia in models with and without global shocks (median of posterior distribution)

Response of debt-to-gdp to fiscal shock

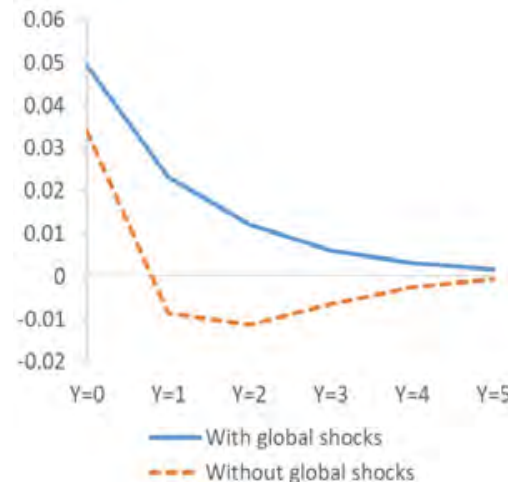

Response of output to fiscal shock

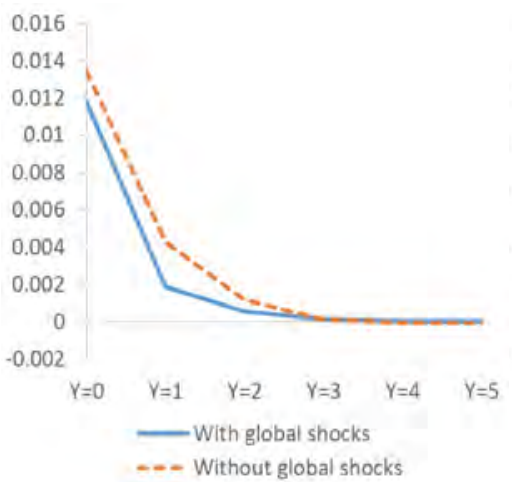

Response of debt-to-gdp to technology shock

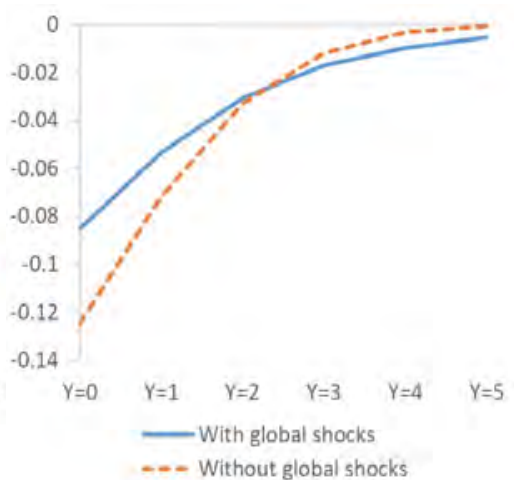

Response of output to technology shock

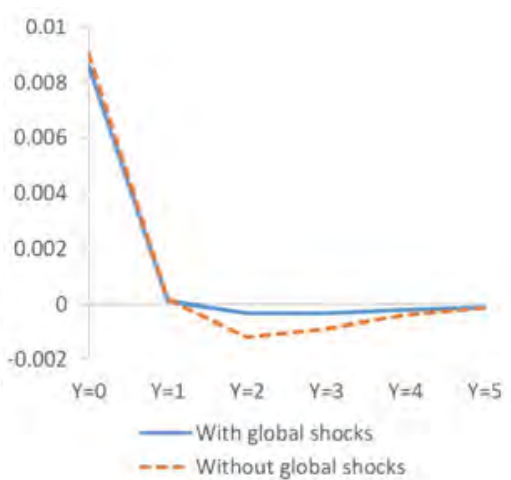

Figure S42: IRFs for Austria in models with and without global shocks (median of posterior distribution)

Response of debt-to-gdp to fiscal shock

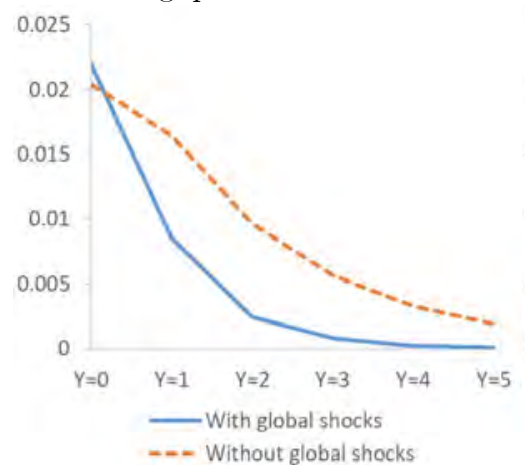

Response of output to fiscal shock

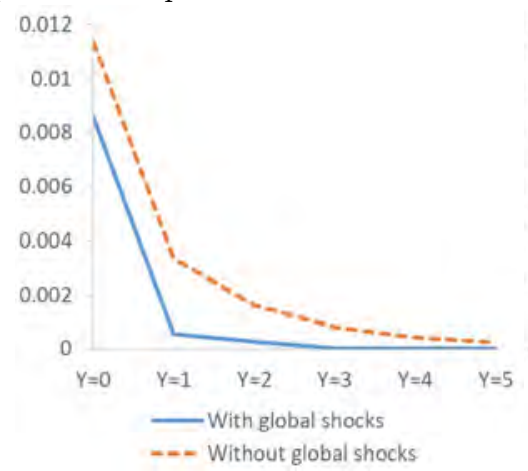

Response of debt-to-gdp to technology shock

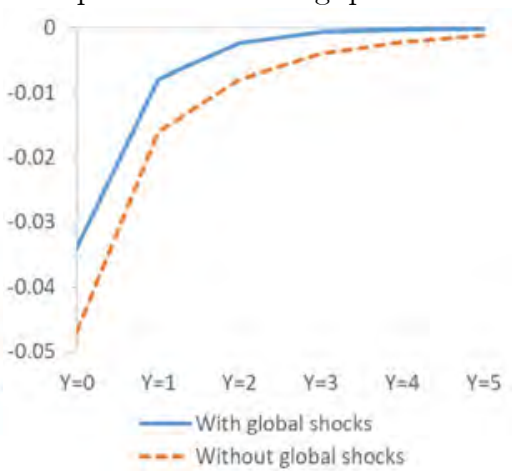

Response of output to technology shock

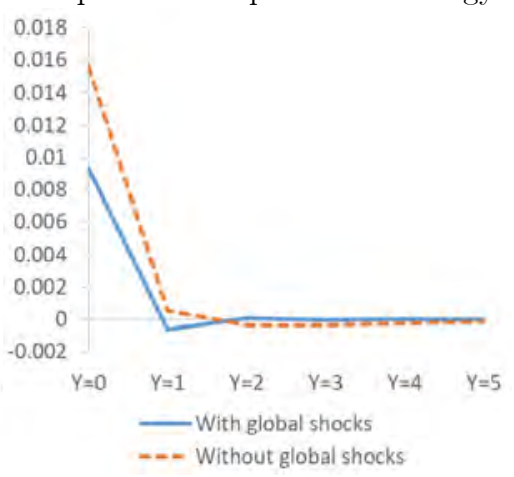


Figure S43: IRFs for Belgium in models with and without global shocks (median of posterior distribution)

Response of debt-to-gdp to fiscal shock

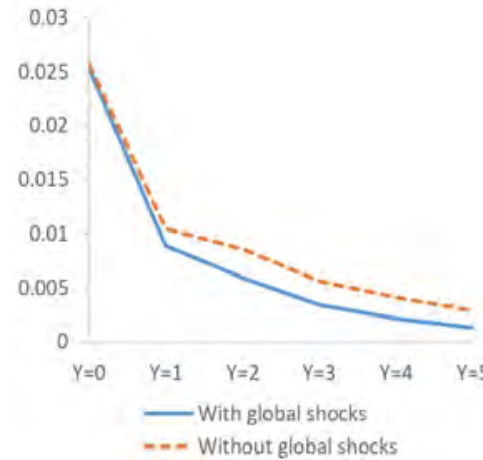

Response of output to fiscal shock

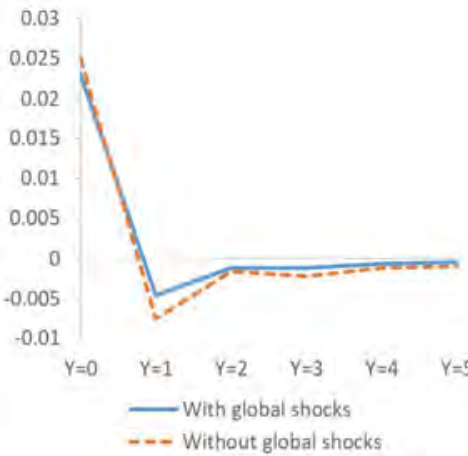

Response of debt-to-gdp to technology shock

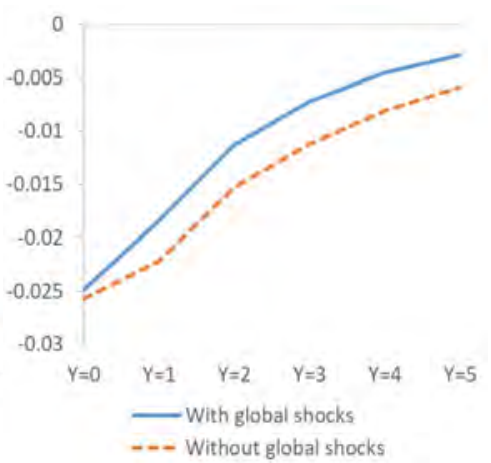

Response of output to technology shock

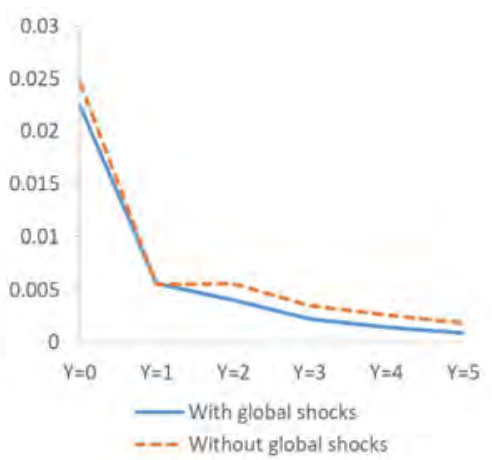

Figure S44: IRFs for Brazil in models with and without global shocks (median of posterior distribution)

Response of debt-to-gdp to fiscal shock

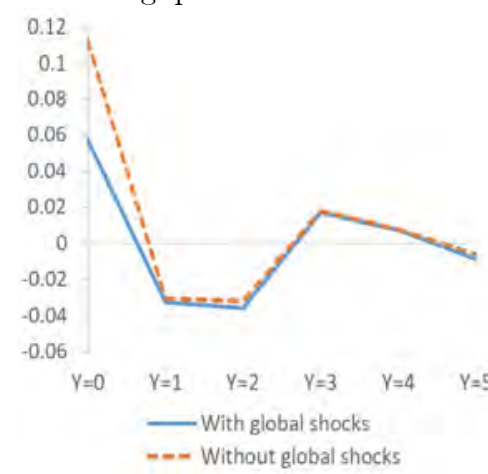

Response of output to fiscal shock

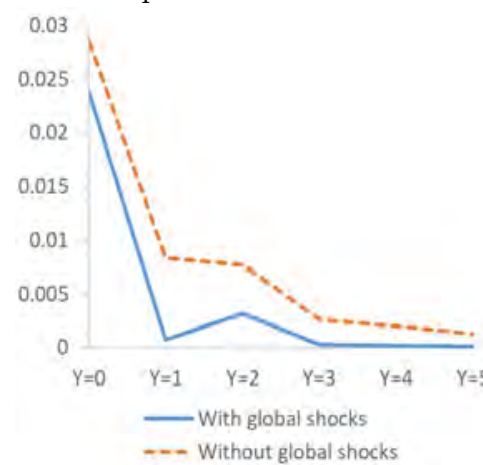

Response of debt-to-gdp to technology shock

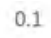

0.05

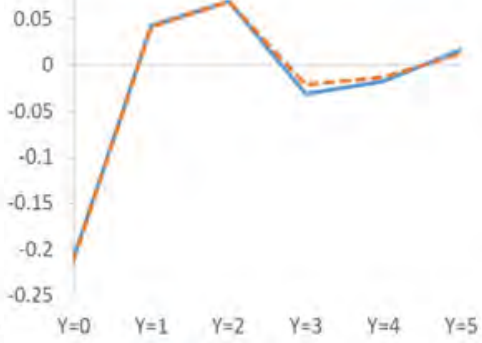

With global shocks

-..- Without global shocks

Response of output to technology shock

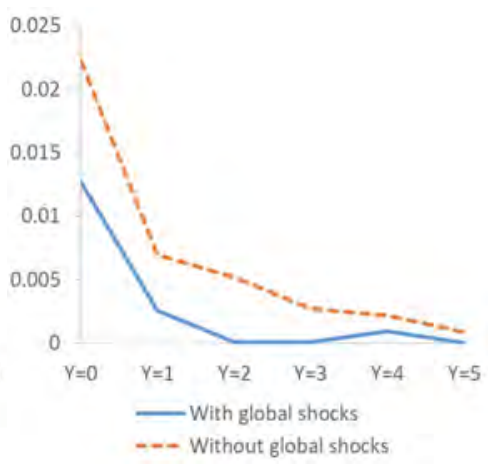


Figure S45: IRFs for Canada in models with and without global shocks (median of posterior distribution)

Response of debt-to-gdp to fiscal shock

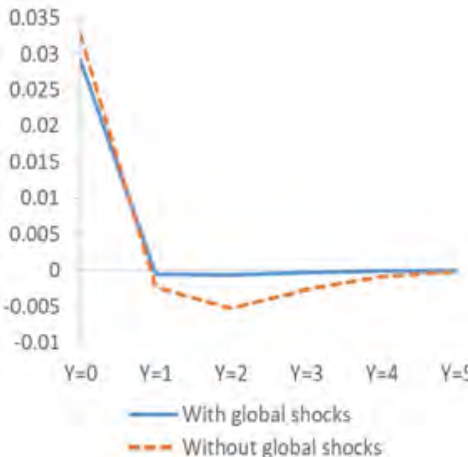

Response of output to fiscal shock

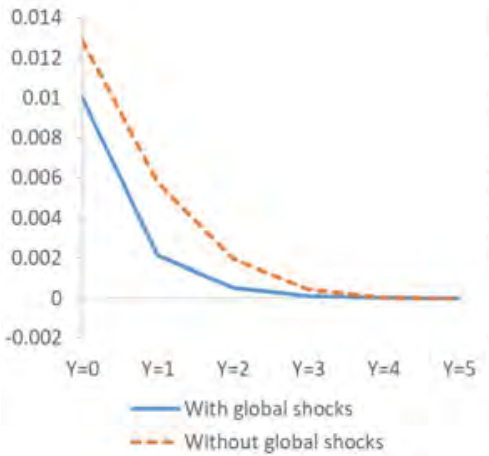

Response of debt-to-gdp to technology shock 0.01

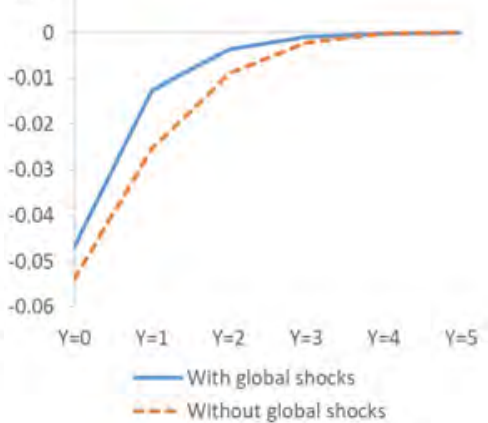

Response of output to technology shock

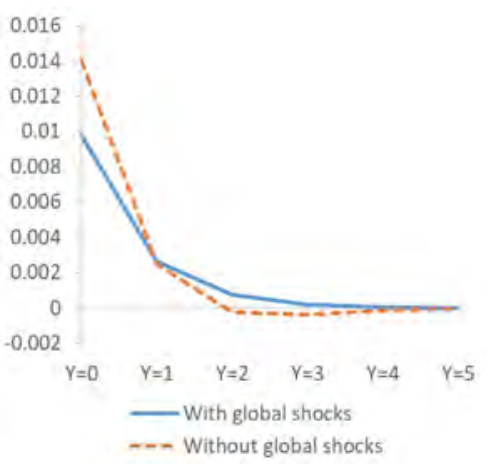

Figure S46: IRFs for Chile in models with and without global shocks (median of posterior distribution)

Response of debt-to-gdp to fiscal shock

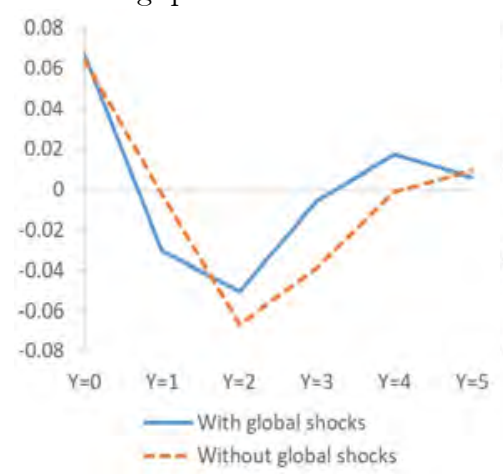

Response of output to fiscal shock

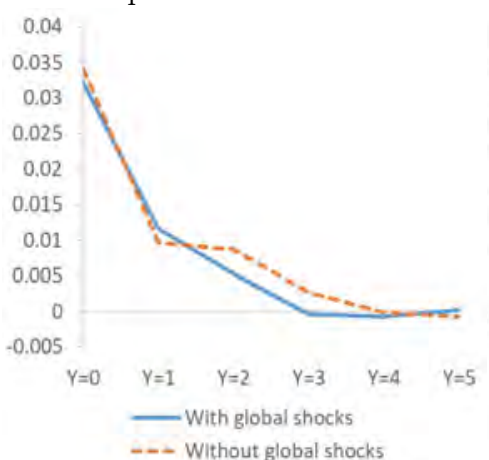

Response of debt-to-gdp to technology shock

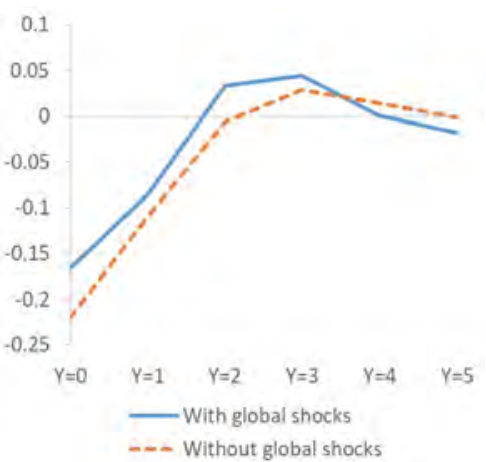

Response of output to technology shock

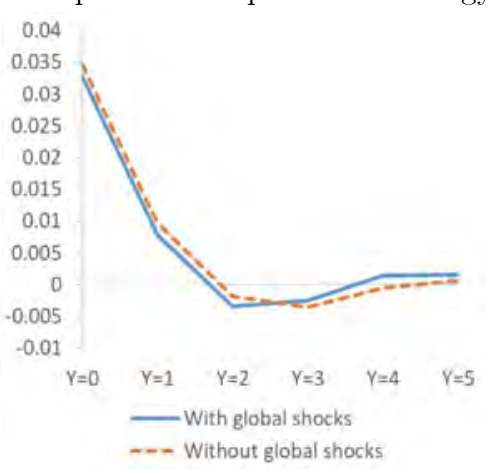


Figure S47: IRFs for China in models with and without global shocks (median of posterior distribution)

Response of debt-to-gdp to fiscal shock

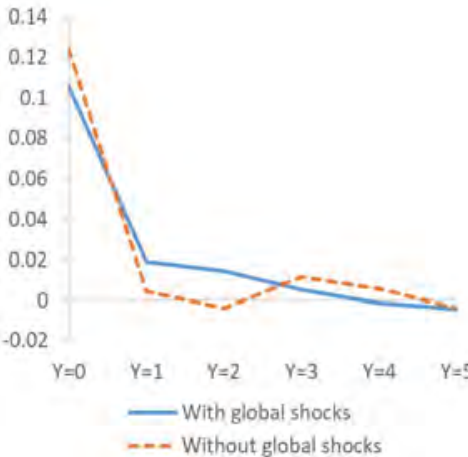

Response of output to fiscal shock

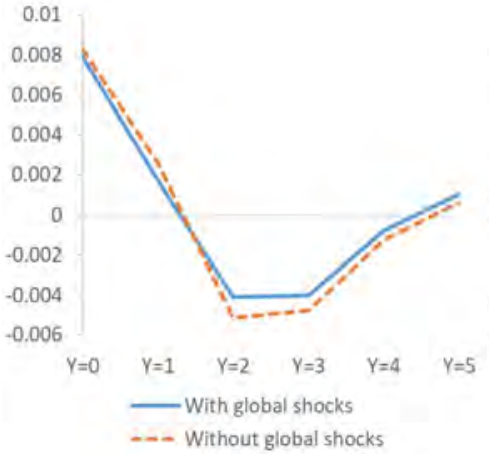

Response of debt-to-gdp to technology shock

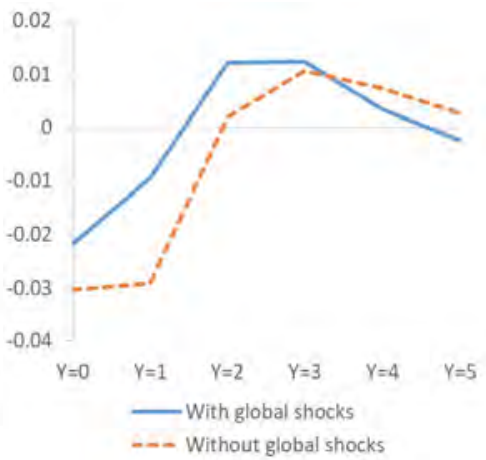

Response of output to technology shock

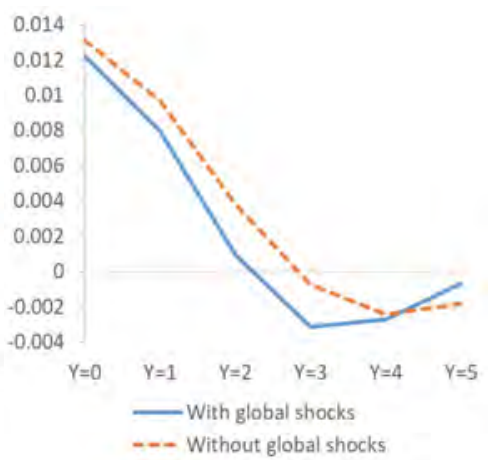

Figure S48: IRFs for Ecuador in models with and without global shocks (median of posterior distribution)

Response of debt-to-gdp to fiscal shock

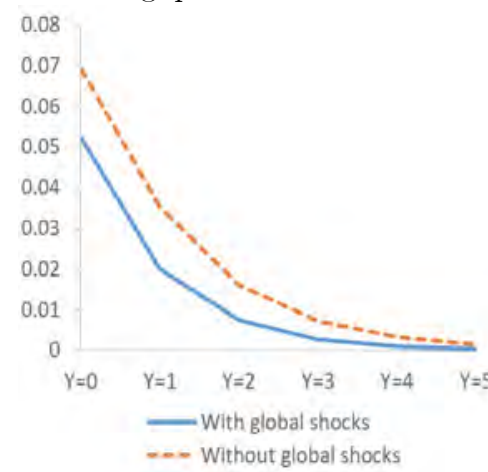

Response of output to fiscal shock

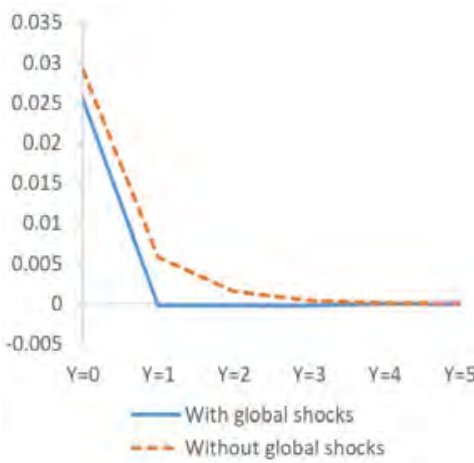

Response of debt-to-gdp to technology shock

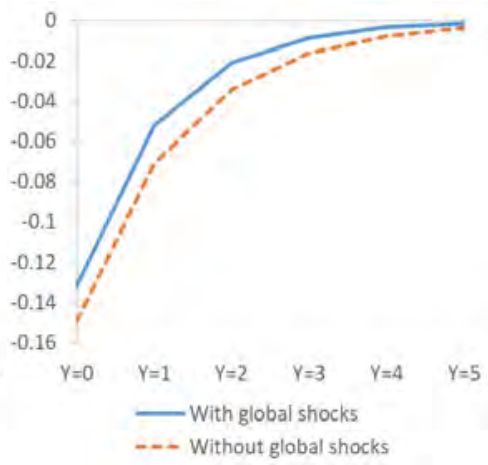

Response of output to technology shock

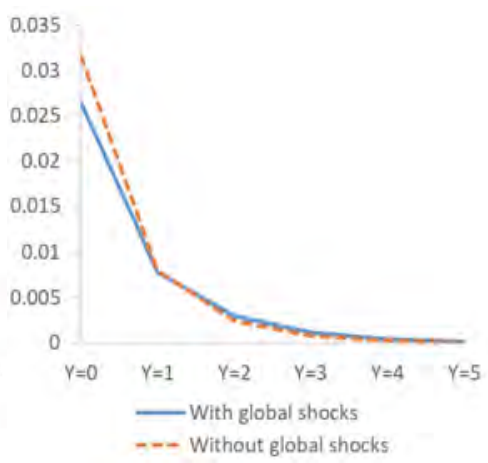


Figure S49: IRFs for Egypt in models with and without global shocks (median of posterior distribution)

Response of debt-to-gdp to fiscal shock

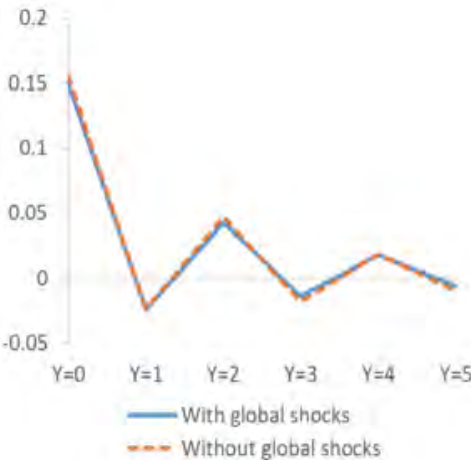

Response of output to fiscal shock

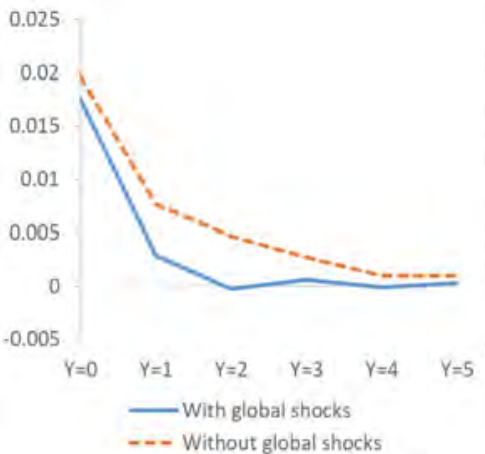

Response of debt-to-gdp to technology shock 0.02

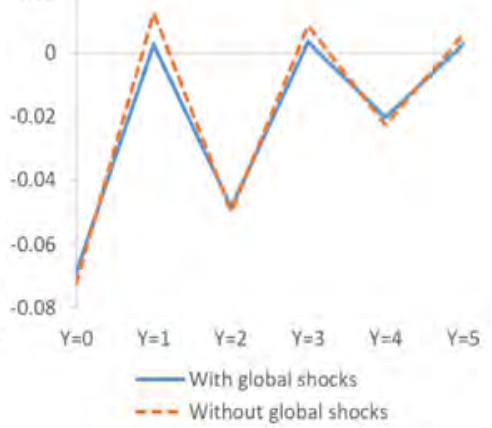

Response of output to technology shock

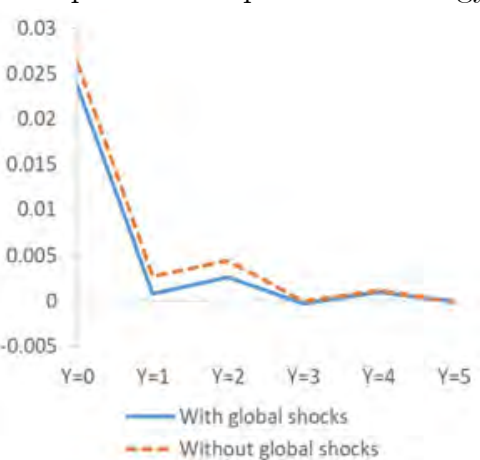

Figure S50: IRFs for Finland in models with and without global shocks (median of posterior distribution)

Response of debt-to-gdp to fiscal shock

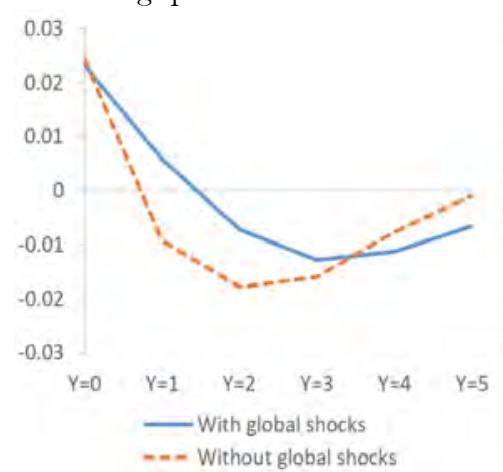

Response of output to fiscal shock

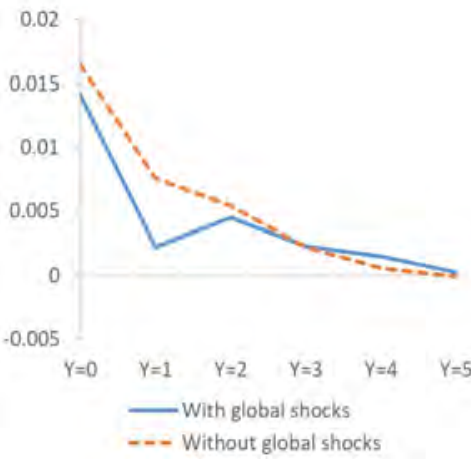

Response of debt-to-gdp to technology shock

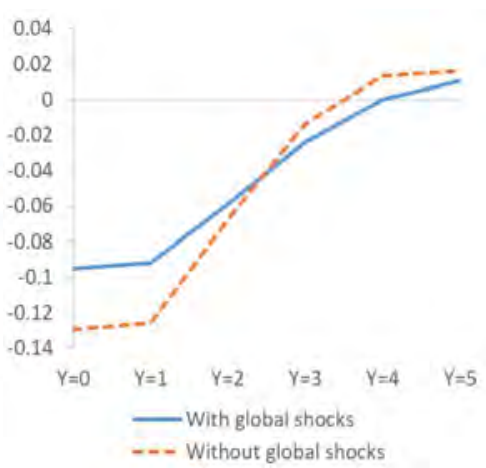

Response of output to technology shock

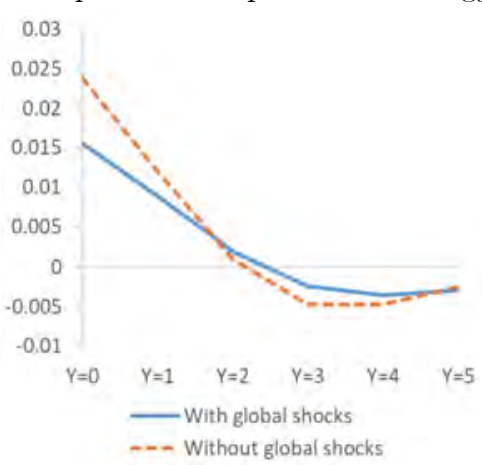


Figure S51: IRFs for France in models with and without global shocks (median of posterior distribution)

Response of debt-to-gdp to fiscal shock

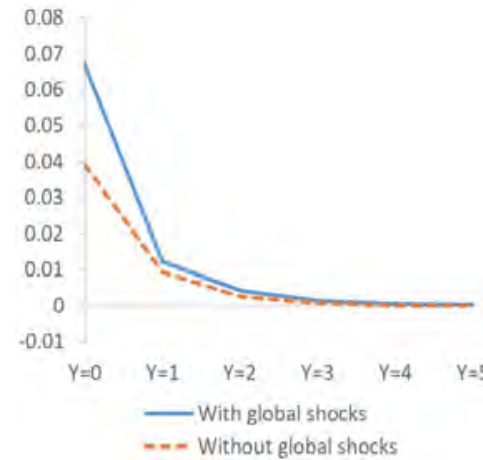

Response of output to fiscal shock

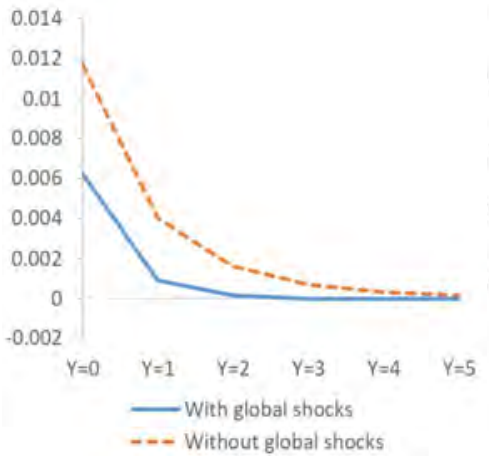

Response of debt-to-gdp to technology shock

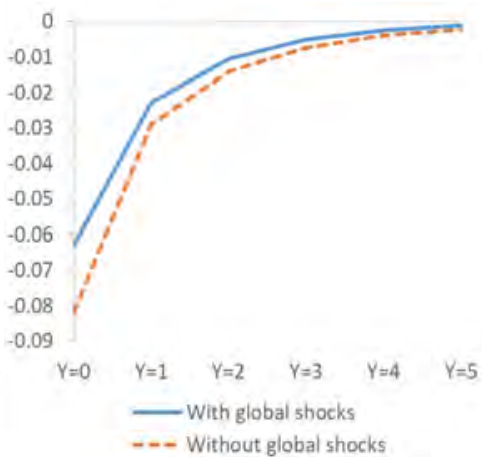

Response of output to technology shock

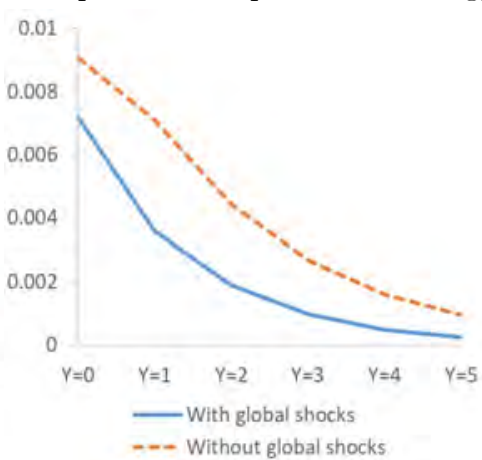

Figure S52: IRFs for Germany in models with and without global shocks (median of posterior distribution)

Response of debt-to-gdp to fiscal shock

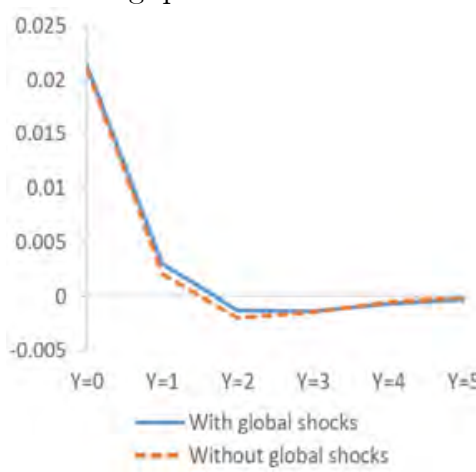

Response of output to fiscal shock

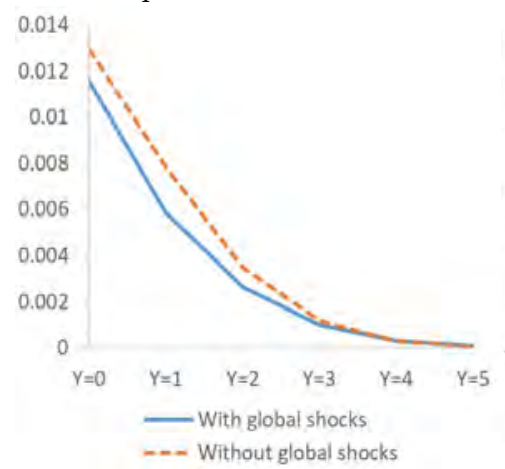

Response of debt-to-gdp to technology shock 0.01

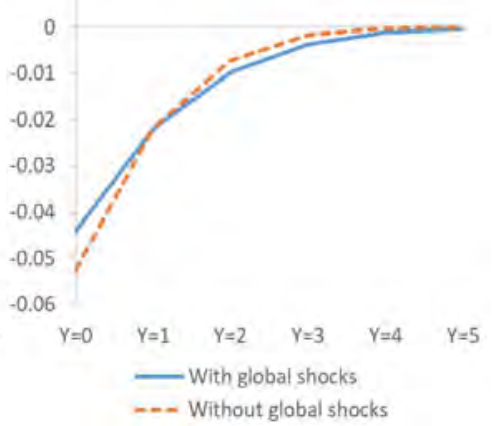

Response of output to technology shock

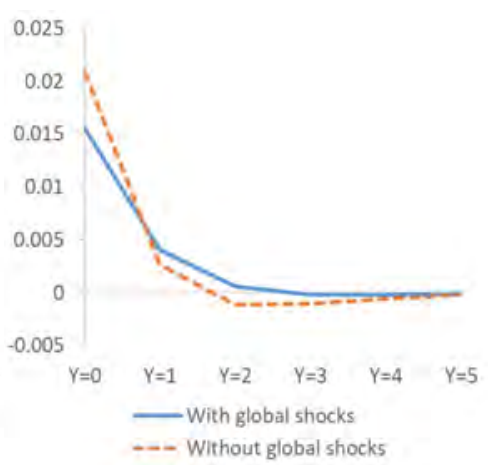


Figure S53: IRFs for India in models with and without global shocks (median of posterior distribution)

Response of debt-to-gdp to fiscal shock

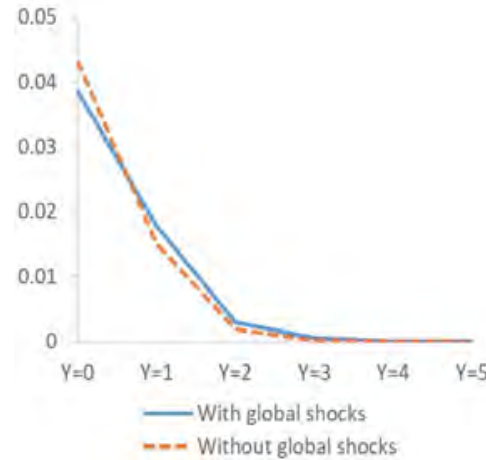

Response of debt-to-gdp to technology shock

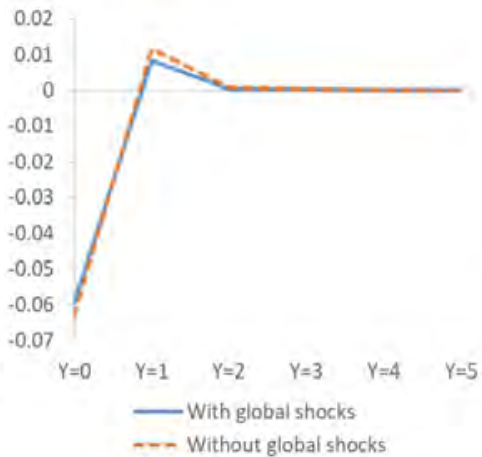

Response of output to fiscal shock

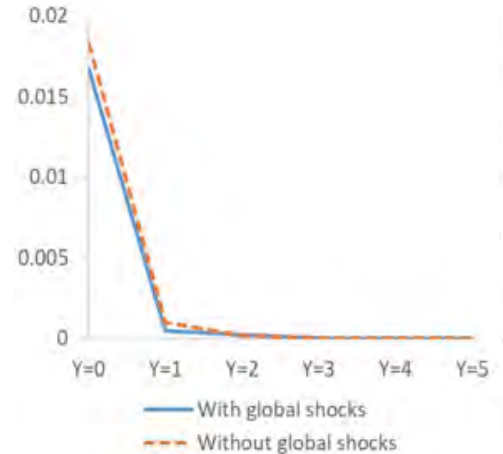

Response of output to technology shock

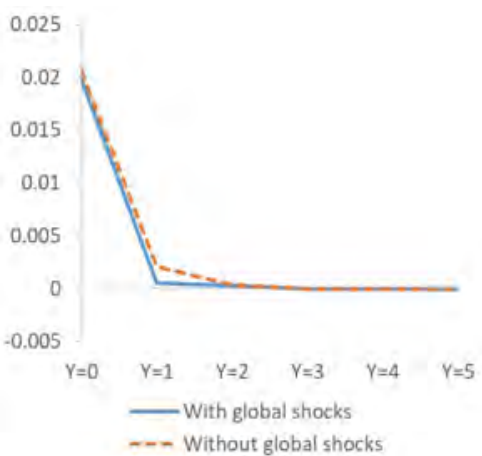

Figure S54: IRFs for Indonesia in models with and without global shocks (median of posterior distribution)

Response of debt-to-gdp to fiscal shock

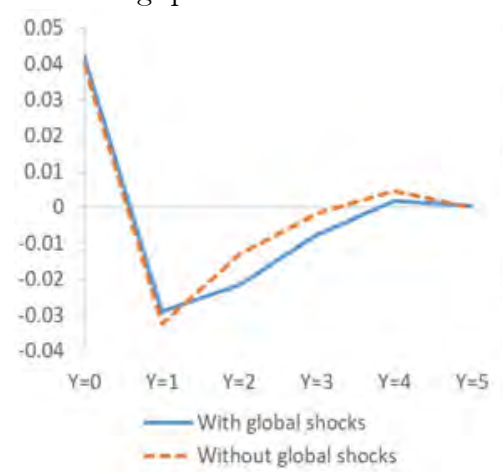

Response of debt-to-gdp to technology shock 0.05

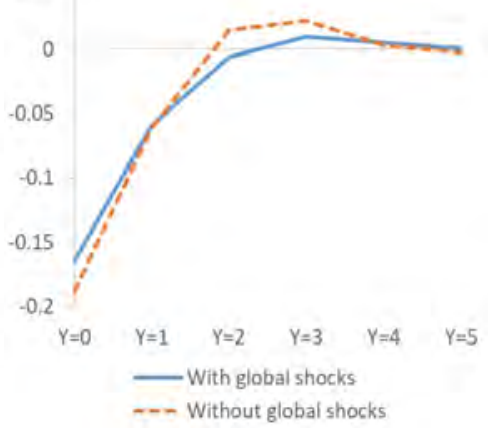

Response of output to fiscal shock

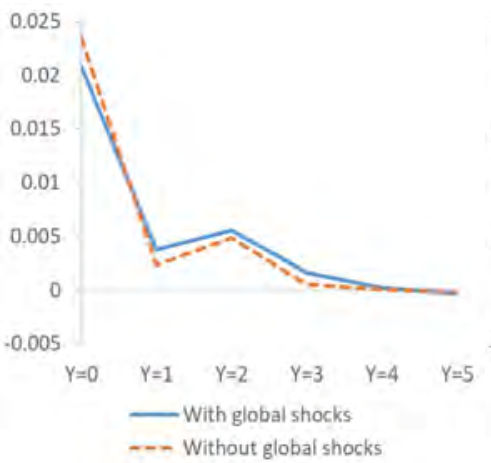

Response of output to technology shock

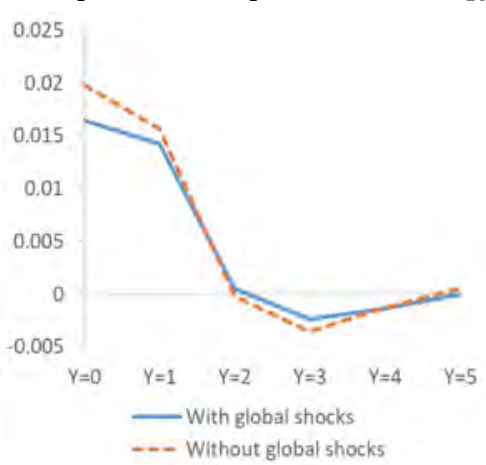


Figure S55: IRFs for Iran in models with and without global shocks (median of posterior distribution)

Response of debt-to-gdp to fiscal shock

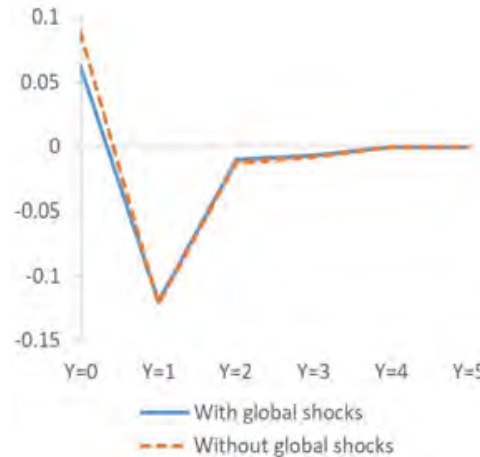

Response of output to fiscal shock

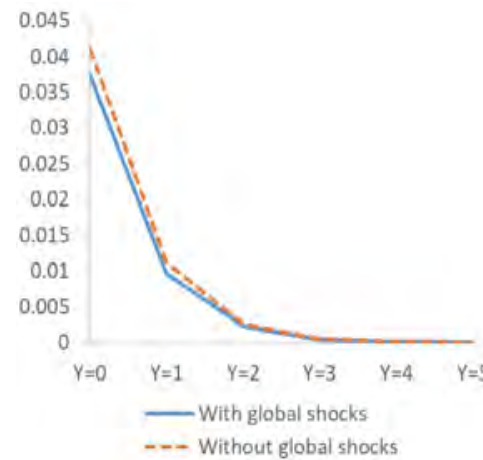

Response of debt-to-gdp to technology shock

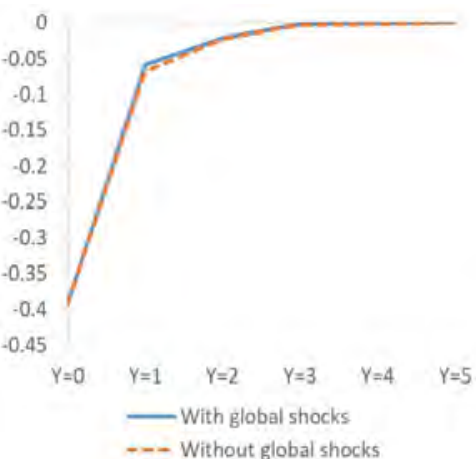

Response of output to technology shock

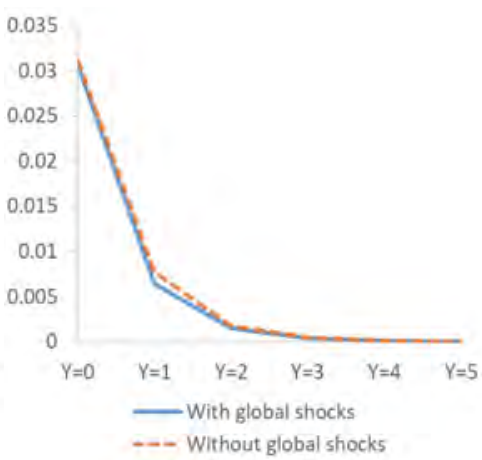

Figure S56: IRFs for Italy in models with and without global shocks (median of posterior distribution)

Response of debt-to-gdp to fiscal shock

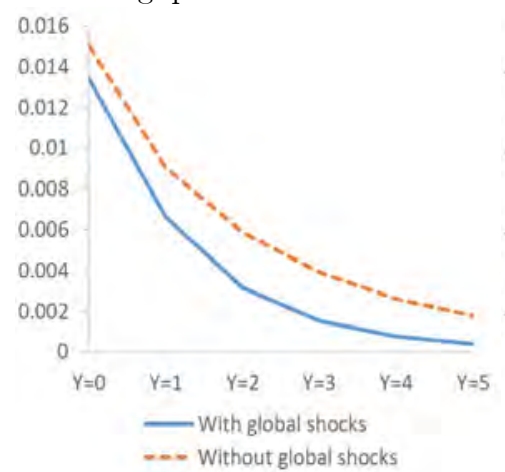

Response of output to fiscal shock

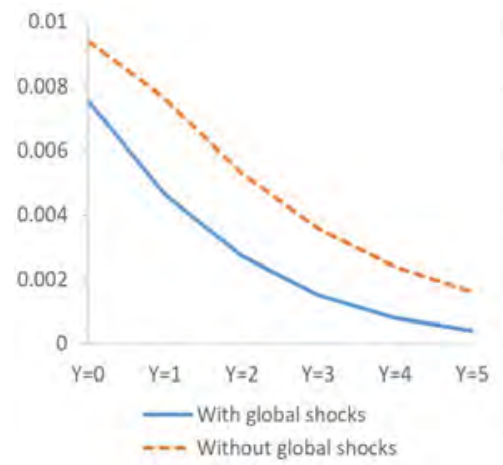

Response of debt-to-gdp to technology shock

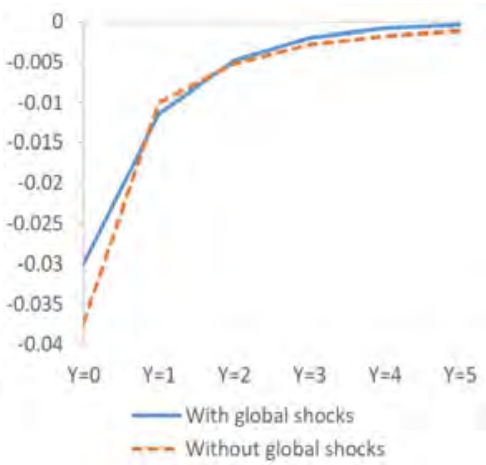

Response of output to technology shock

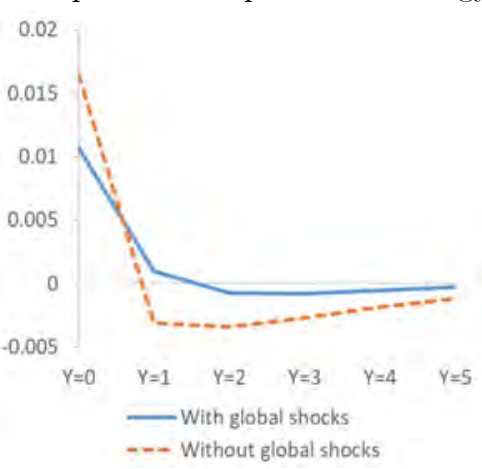


Figure S57: IRFs for Japan in models with and without global shocks (median of posterior distribution)

Response of debt-to-gdp to fiscal shock

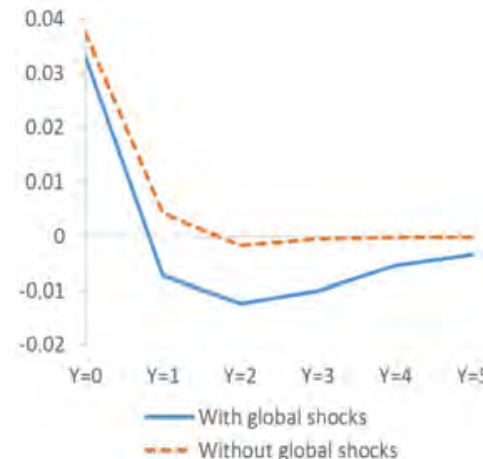

Response of output to fiscal shock 0.025

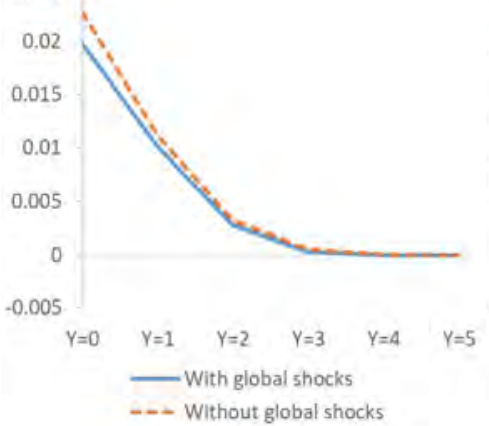

Response of debt-to-gdp to technology shock

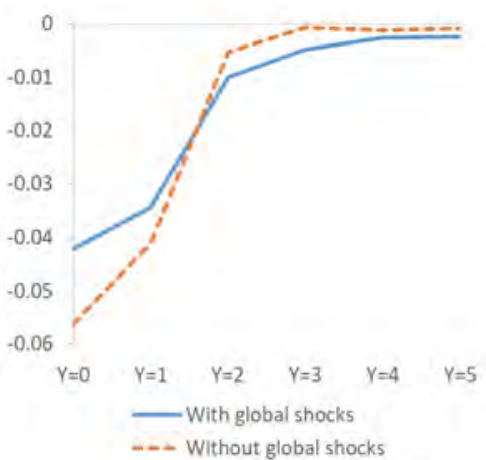

Response of output to technology shock

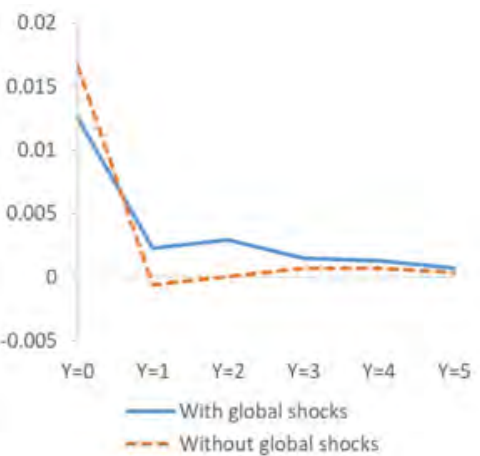

Figure S58: IRFs for Korea in models with and without global shocks (median of posterior distribution)

Response of debt-to-gdp to fiscal shock

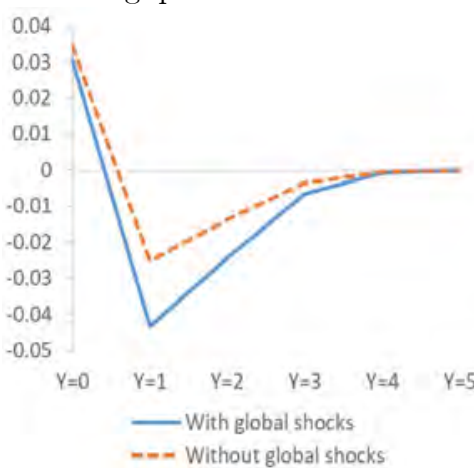

Response of output to fiscal shock

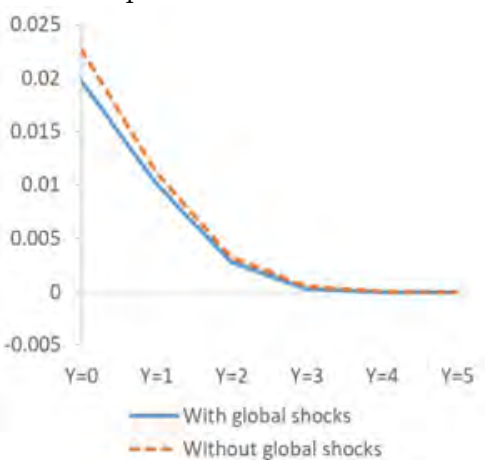

Response of debt-to-gdp to technology shock 0.05

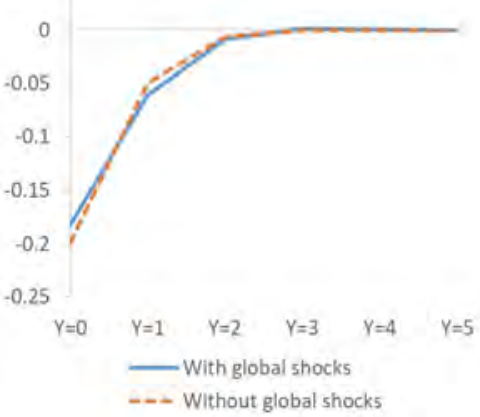

Response of output to technology shock

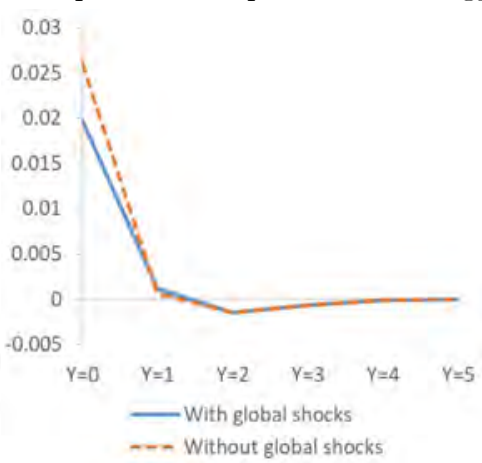


Figure S59: IRFs for Malaysia in models with and without global shocks (median of posterior distribution)

Response of debt-to-gdp to fiscal shock

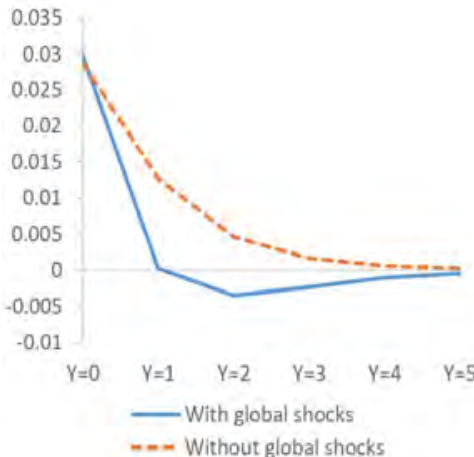

Response of output to fiscal shock

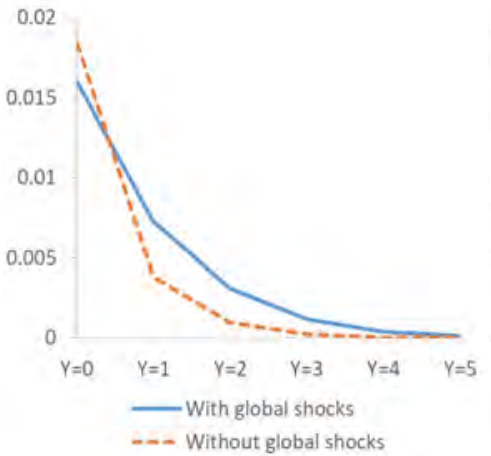

Response of debt-to-gdp to technology shock

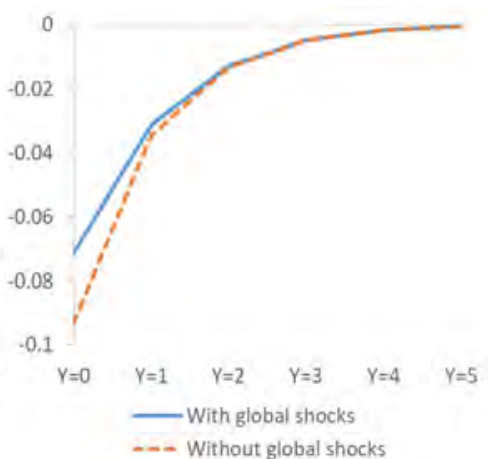

Response of output to technology shock

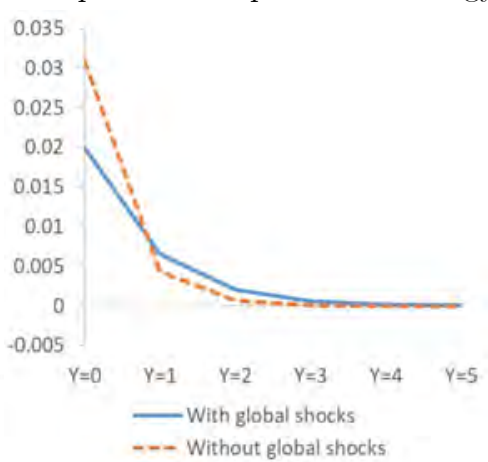

Figure S60: IRFs for Mexico in models with and without global shocks (median of posterior distribution)

Response of debt-to-gdp to fiscal shock

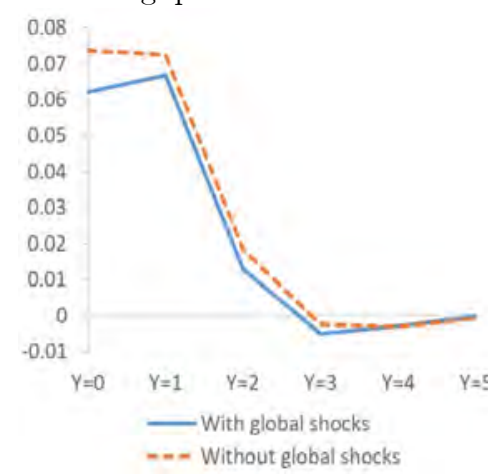

Response of output to fiscal shock

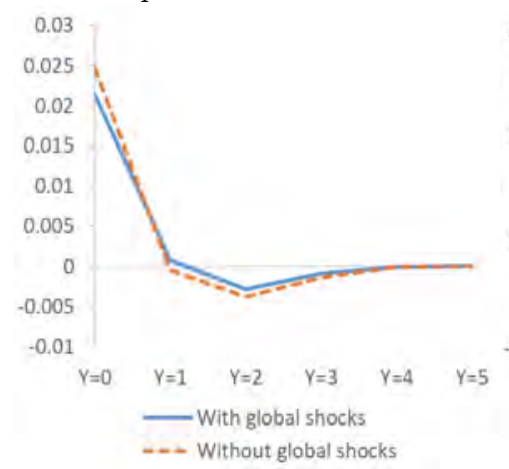

Response of debt-to-gdp to technology shock

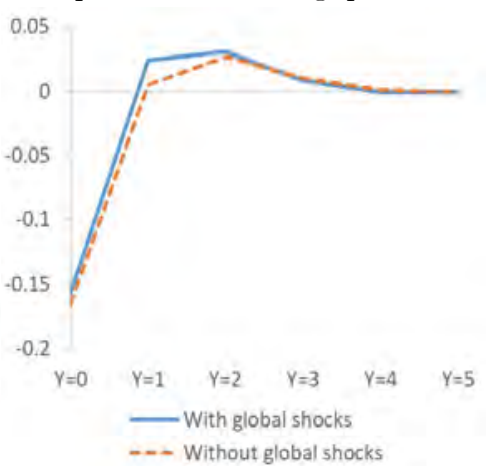

Response of output to technology shock

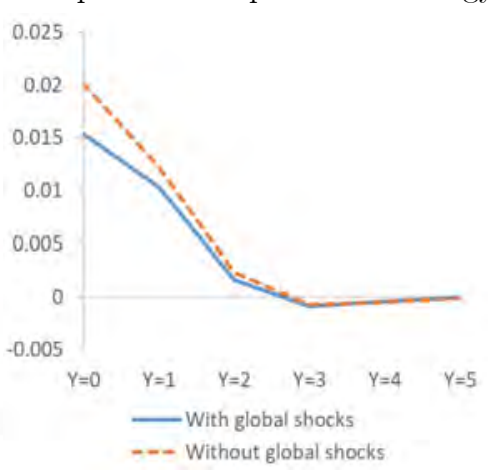


Figure S61: IRFs for Morocco in models with and without global shocks (median of posterior distribution)

Response of debt-to-gdp to fiscal shock

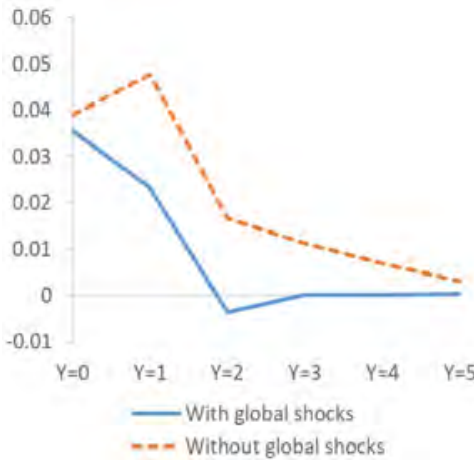

Response of output to fiscal shock

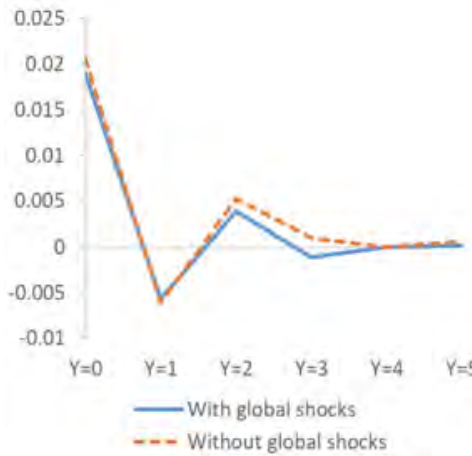

Response of debt-to-gdp to technology shock

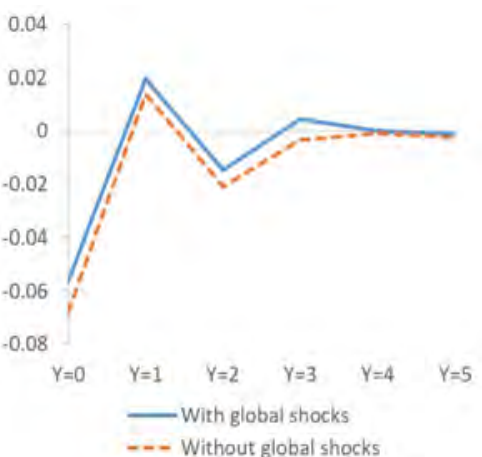

Response of output to technology shock

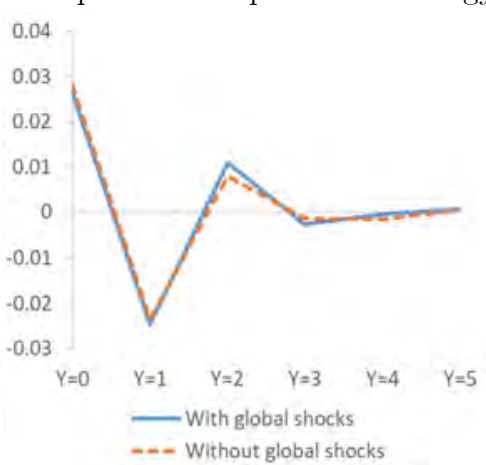

Figure S62: IRFs for Netherlands in models with and without global shocks (median of posterior distribution)

Response of debt-to-gdp to fiscal shock

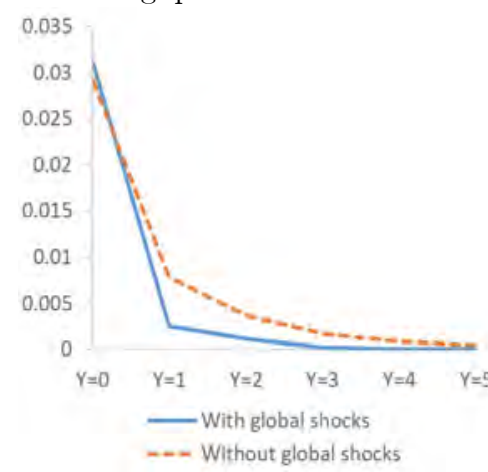

Response of output to fiscal shock

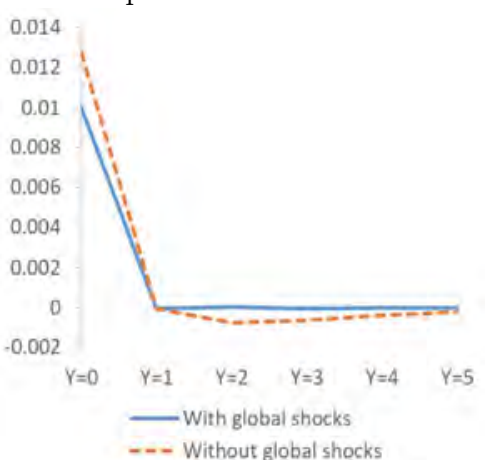

Response of debt-to-gdp to technology shock

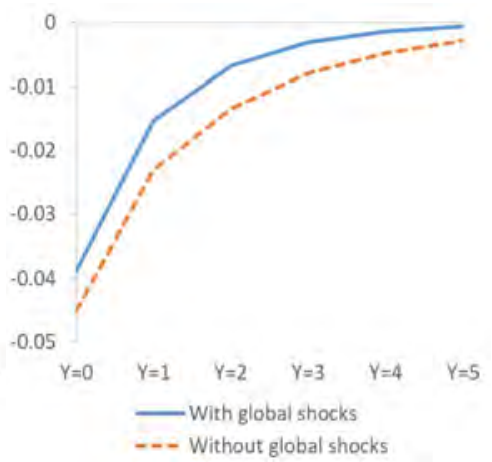

Response of output to technology shock

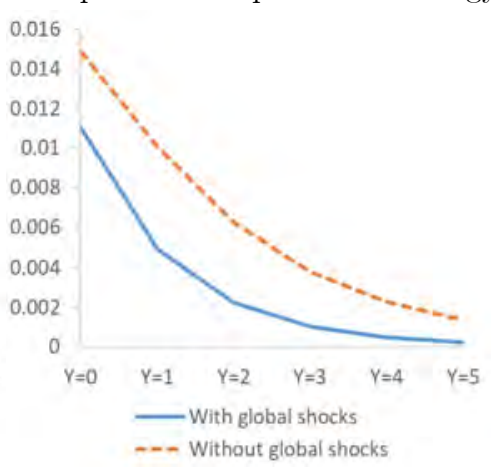


Figure S63: IRFs for New Zealand in models with and without global shocks (median of posterior distribution)

Response of debt-to-gdp to fiscal shock

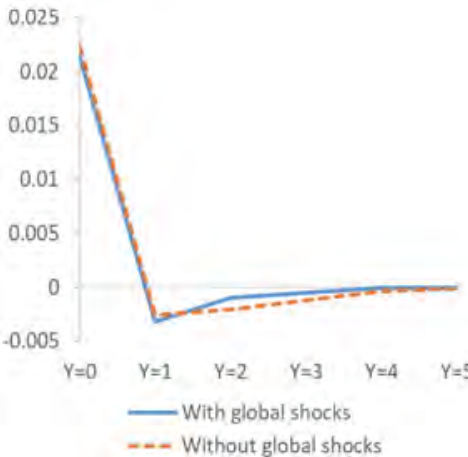

Response of output to fiscal shock

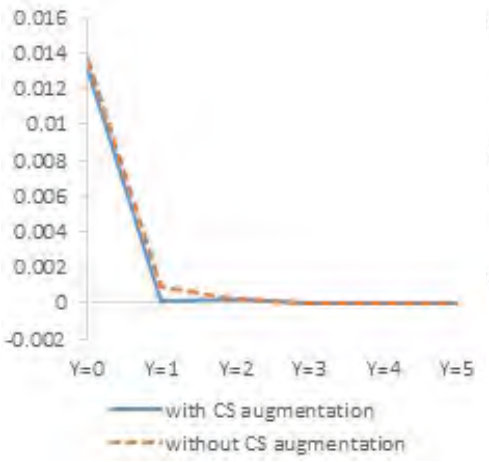

Response of debt-to-gdp to technology shock

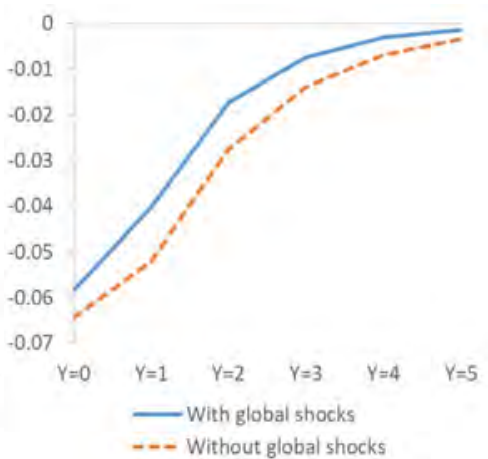

Response of output to technology shock

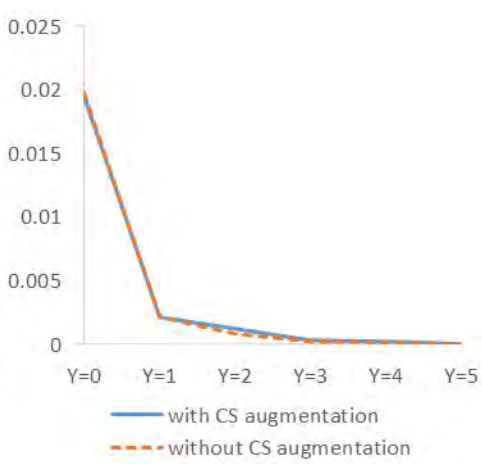

Figure S64: IRFs for Nigeria in models with and without global shocks (median of posterior distribution)

Response of debt-to-gdp to fiscal shock

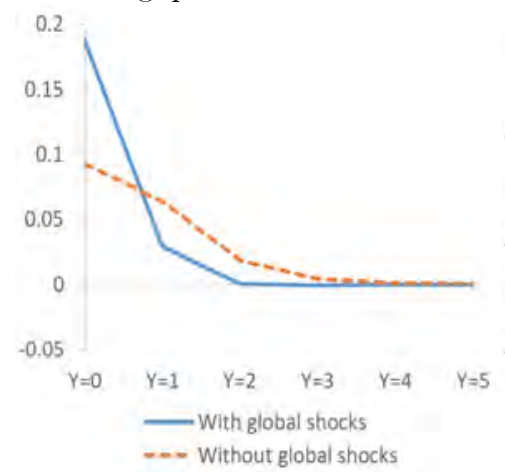

Response of output to fiscal shock

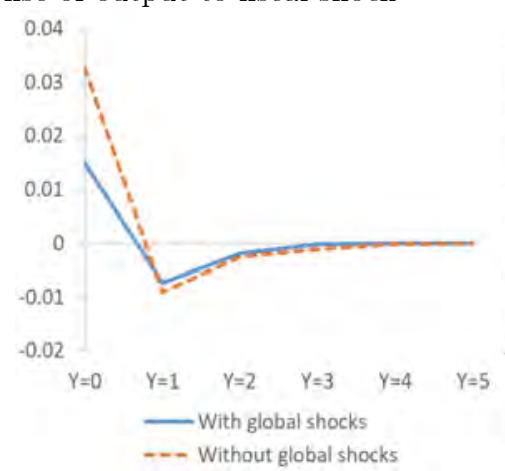

Response of debt-to-gdp to technology shock 0.05

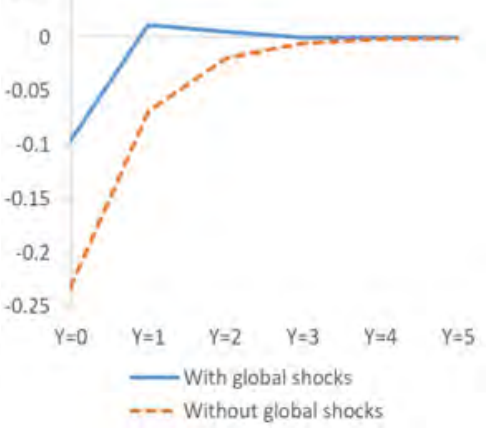

Response of output to technology shock

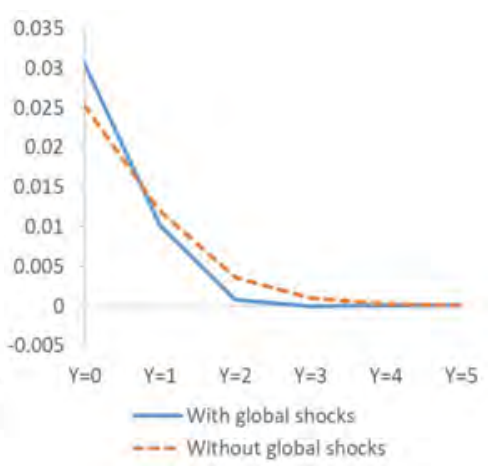


Figure S65: IRFs for Norway in models with and without global shocks (median of posterior distribution)

Response of debt-to-gdp to fiscal shock

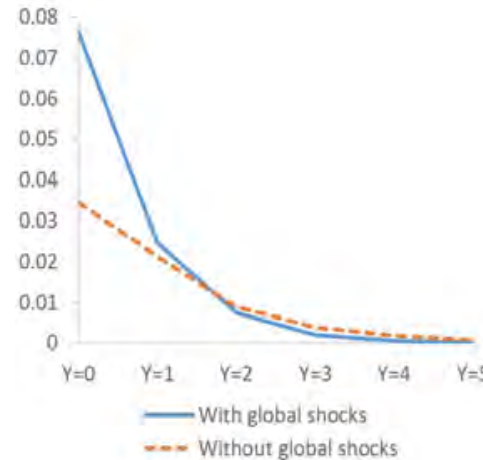

Response of output to fiscal shock

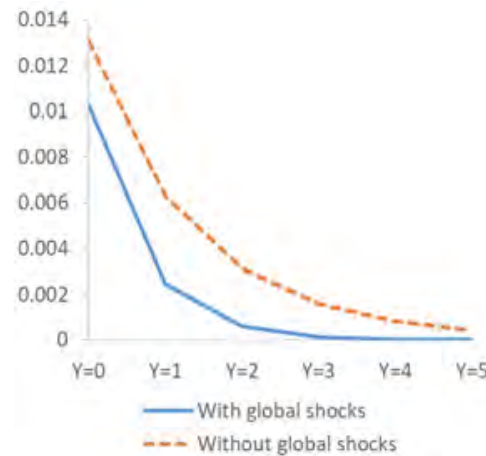

Response of debt-to-gdp to technology shock 0.02

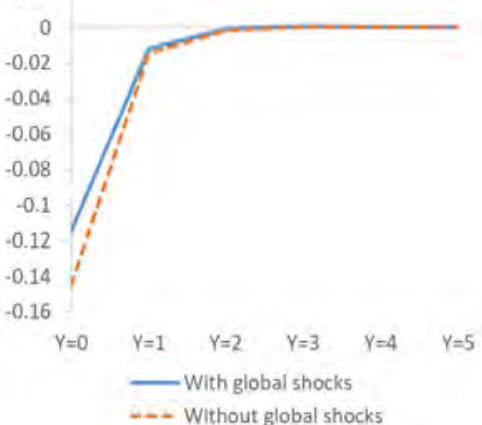

Response of output to technology shock

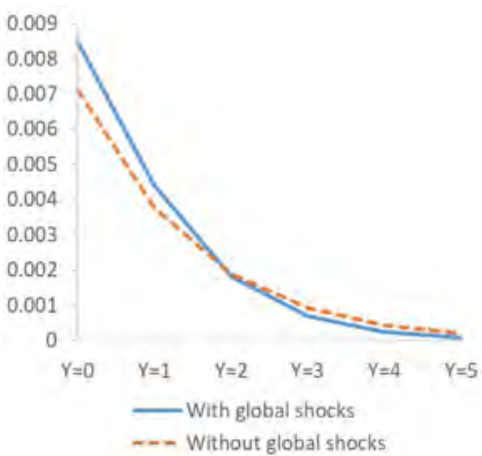

Figure S66: IRFs for Peru in models with and without global shocks (median of posterior distribution)

Response of debt-to-gdp to fiscal shock

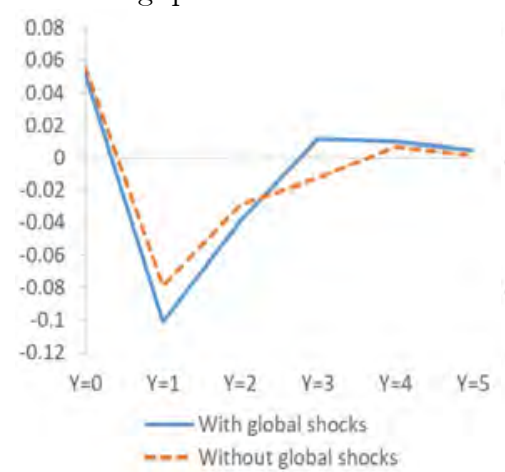

Response of output to fiscal shock

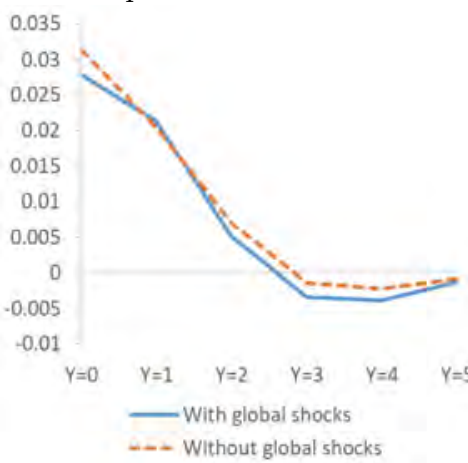

Response of debt-to-gdp to technology shock 0.05

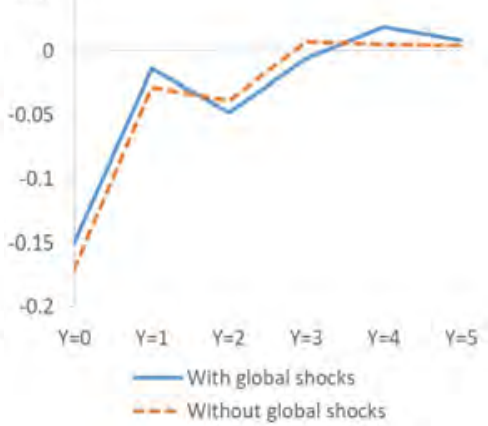

Response of output to technology shock

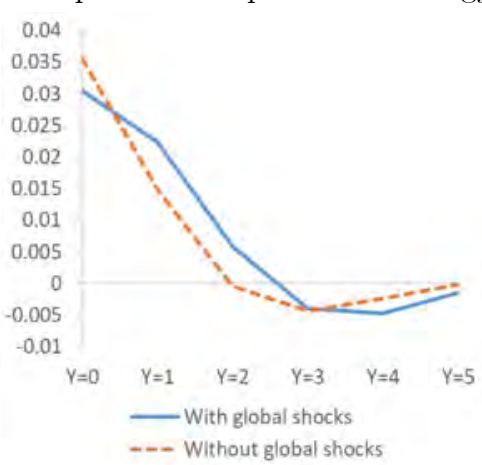


Figure S67: IRFs for Philippines in models with and without CS augmentation (median of posterior distribution)

Response of debt-to-gdp to fiscal shock

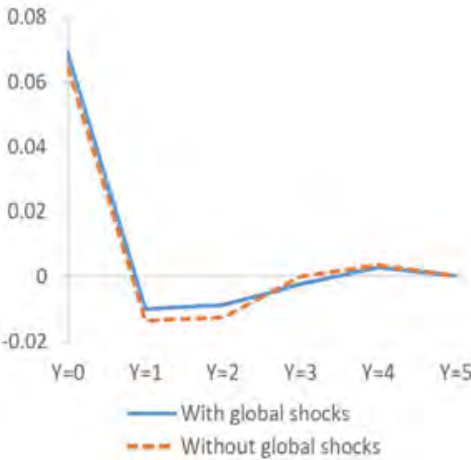

Response of output to fiscal shock

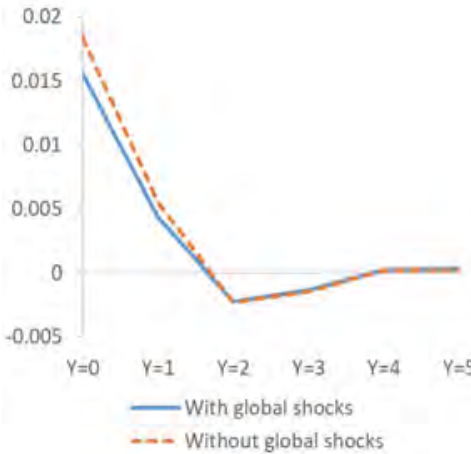

Response of debt-to-gdp to technology shock

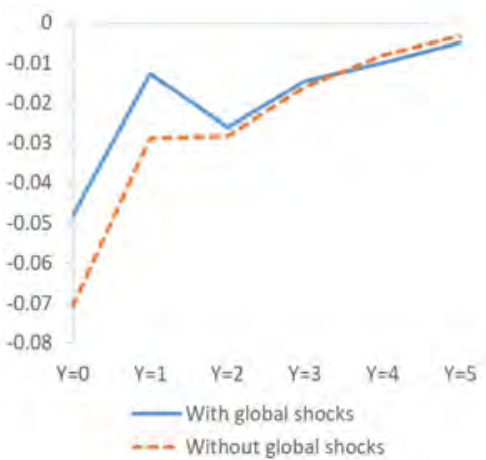

Response of output to technology shock

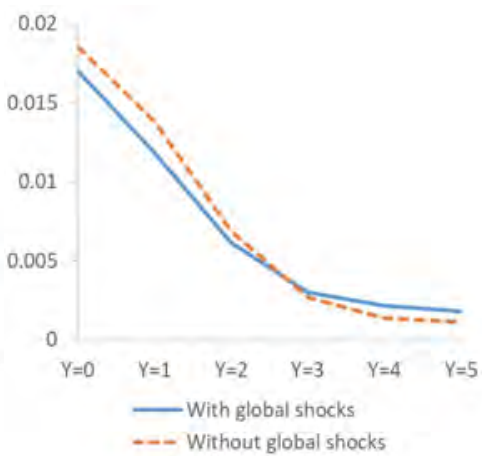

Figure S68 IRFs for Singapore in models with and without global shocks (median of posterior distribution)

Response of debt-to-gdp to fiscal shock

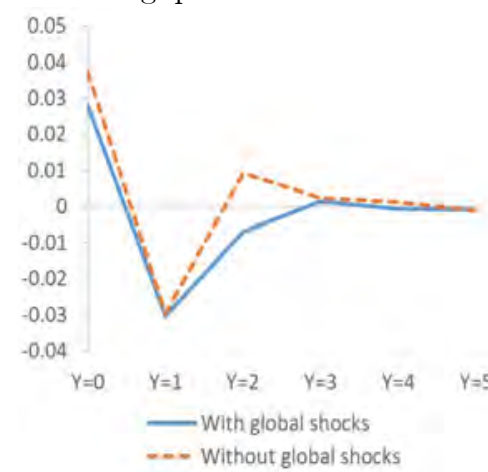

Response of output to fiscal shock

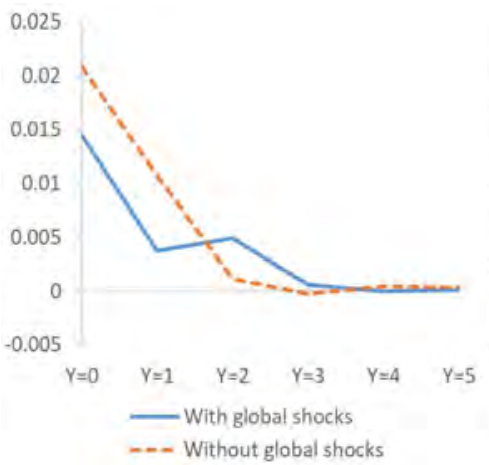

Response of debt-to-gdp to technology shock

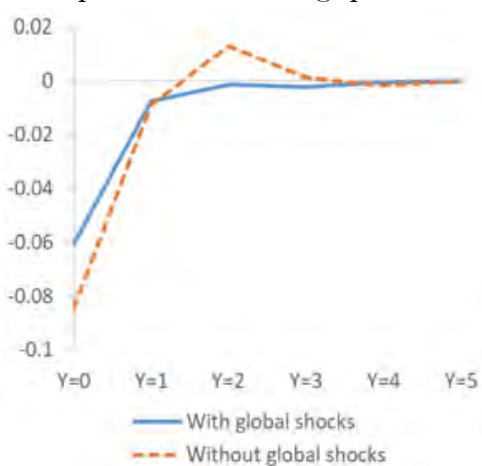

Response of output to technology shock

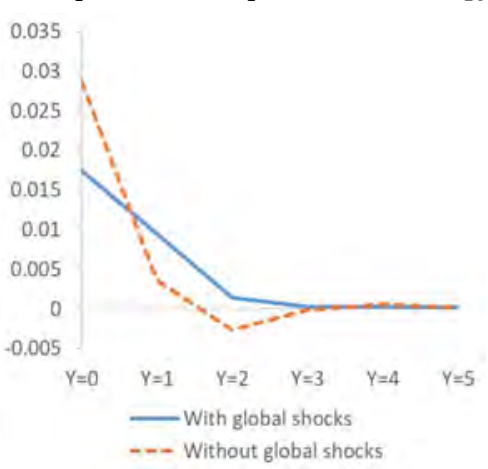


Figure S69: IRFs for South Africa in models with and without global shocks (median of posterior distribution)

Response of debt-to-gdp to fiscal shock

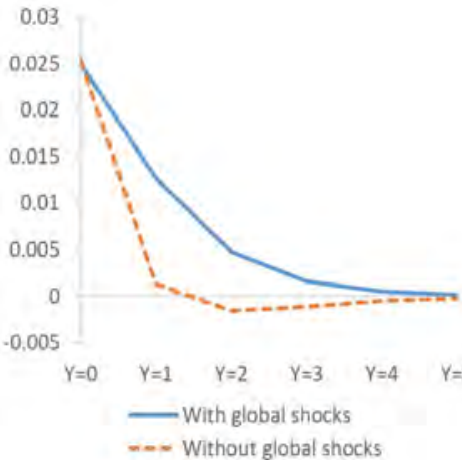

Response of output to fiscal shock

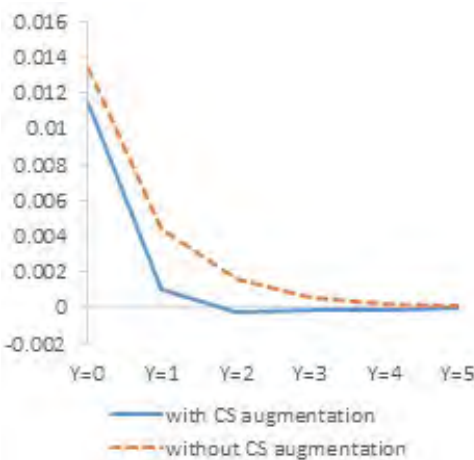

Response of debt-to-gdp to technology shock

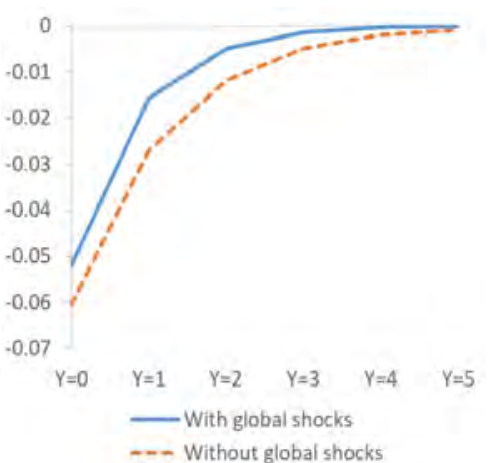

Response of output to technology shock

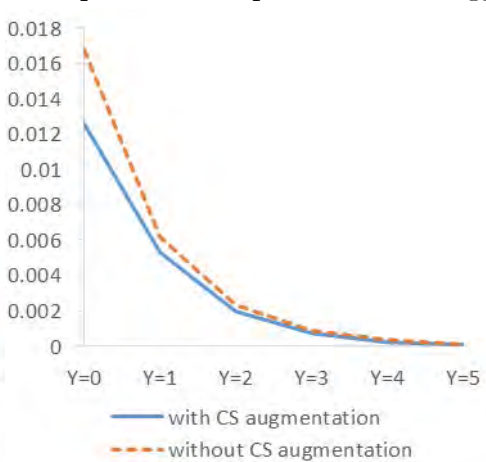

Figure S70: IRFs for Spain in models with and without global shocks (median of posterior distribution)

Response of debt-to-gdp to fiscal shock

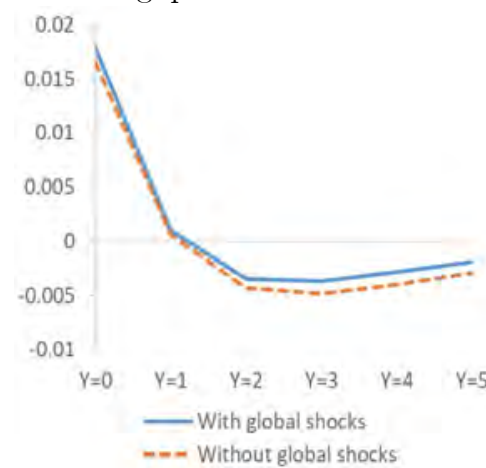

Response of output to fiscal shock

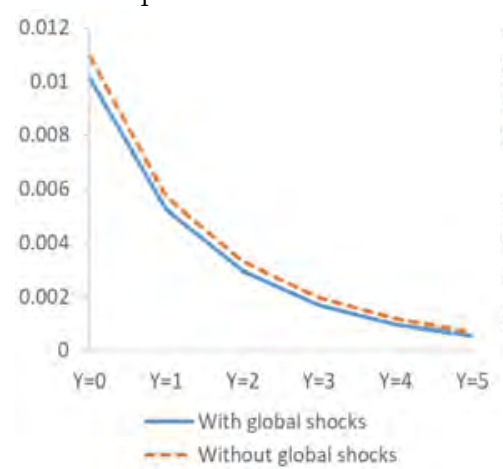

Response of debt-to-gdp to technology shock

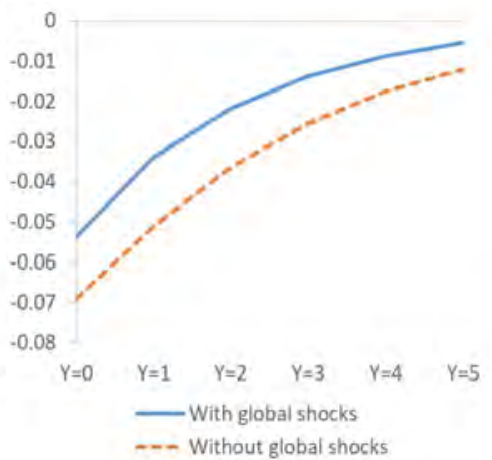

Response of output to technology shock

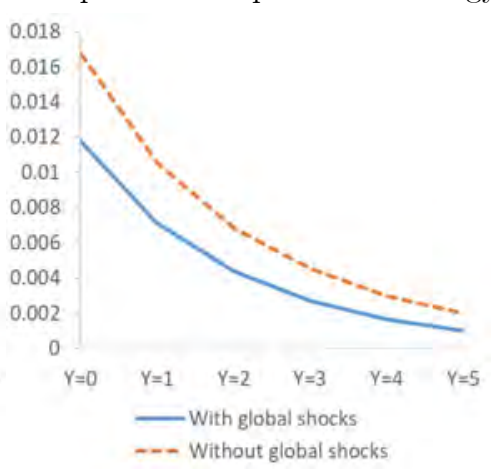


Figure S71: IRFs for Sweden in models with and without global shocks (median of posterior distribution)

Response of debt-to-gdp to fiscal shock

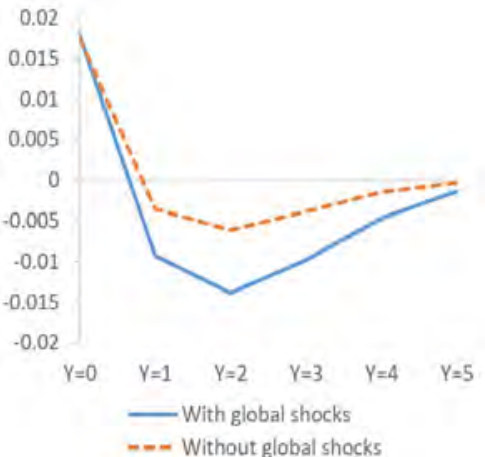

Response of output to fiscal shock

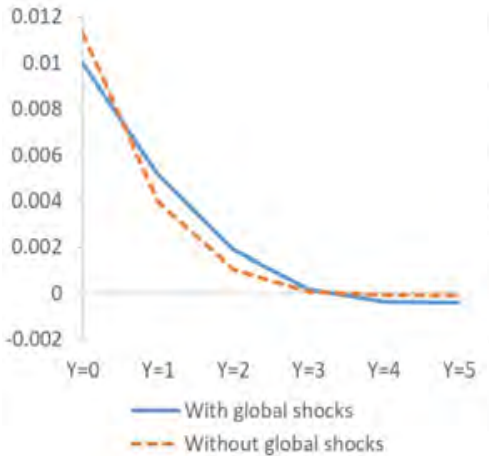

Response of debt-to-gdp to technology shock 0.01

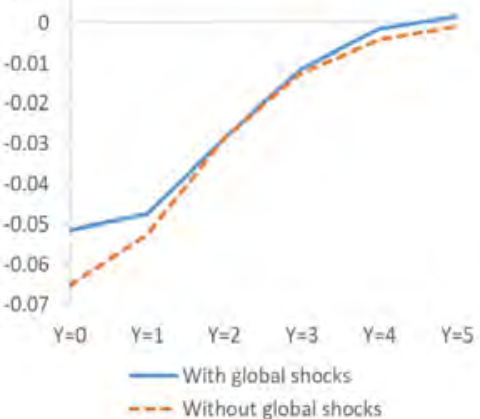

Response of output to technology shock

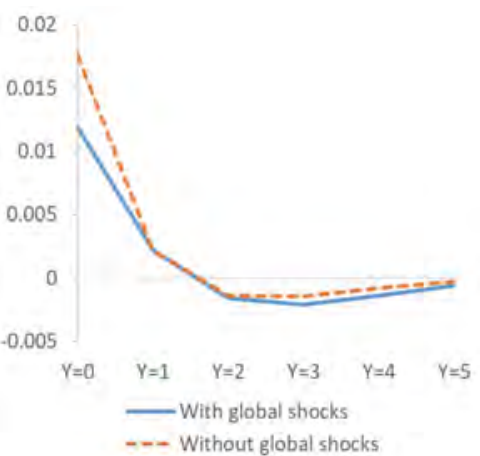

Figure S72: IRFs for Switzerland in models with and without global shocks (median of posterior distribution)

Response of debt-to-gdp to fiscal shock

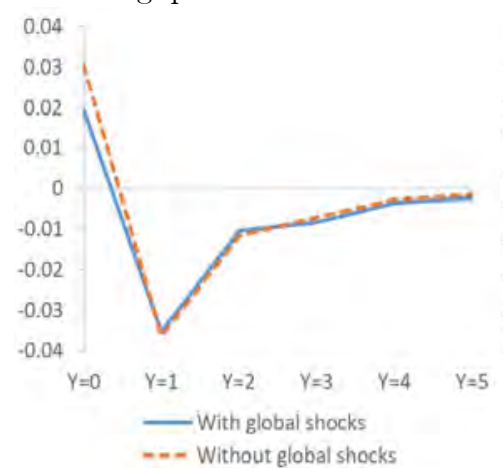

Response of output to fiscal shock

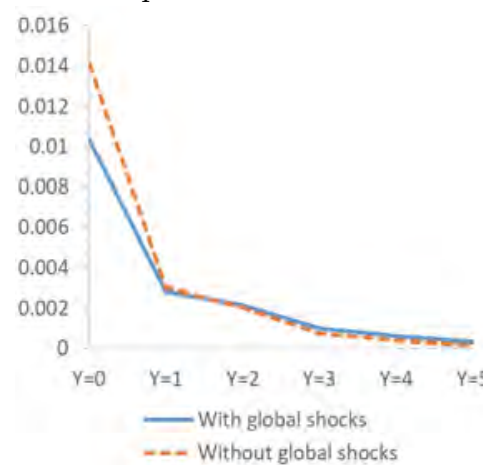

Response of debt-to-gdp to technology shock

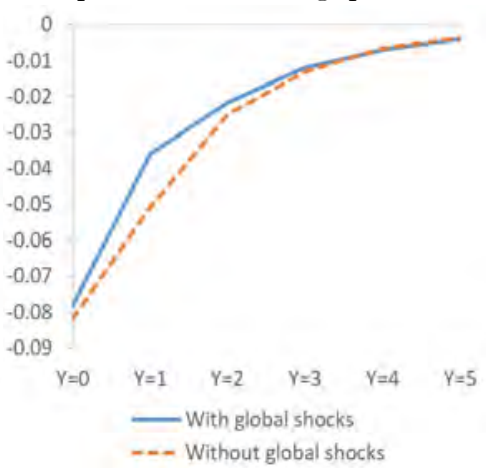

Response of output to technology shock

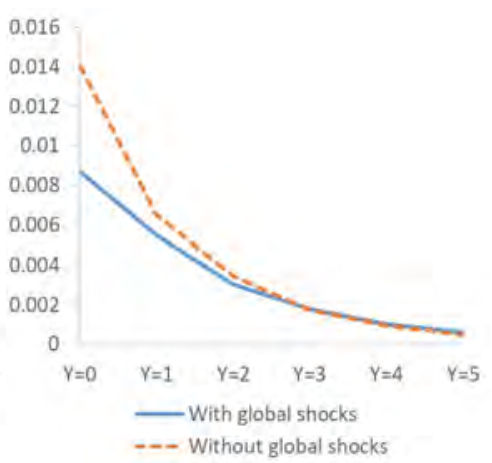


Figure S73: IRFs for Thailand in models with and without global shocks (median of posterior distribution)

Response of debt-to-gdp to fiscal shock

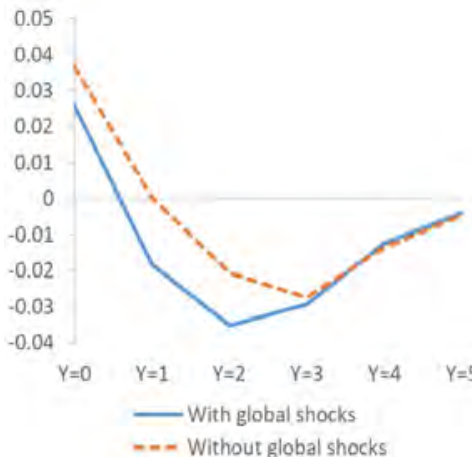

Response of output to fiscal shock

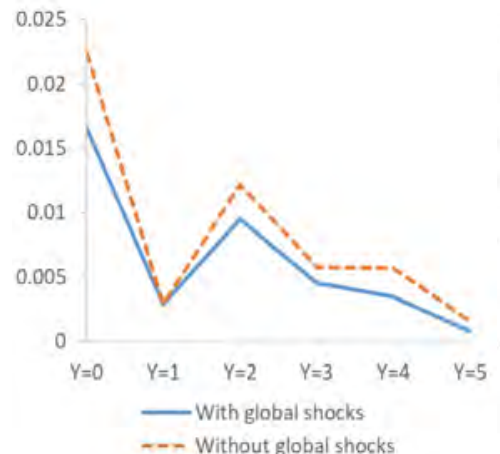

Response of debt-to-gdp to technology shock

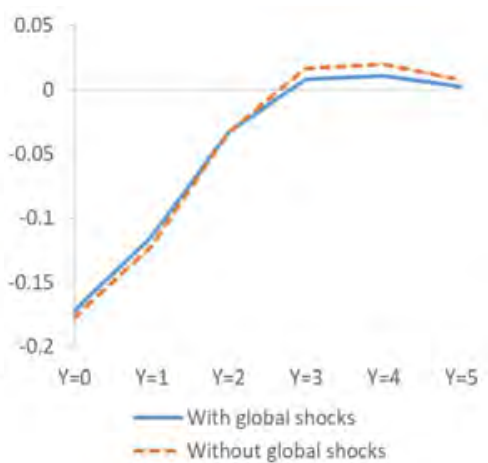

Response of output to technology shock

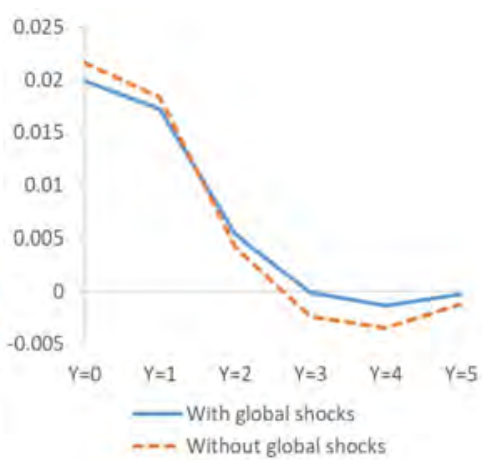

Figure S74: IRFs for Tunisia in models with and without global shocks (median of posterior distribution)

Response of debt-to-gdp to fiscal shock

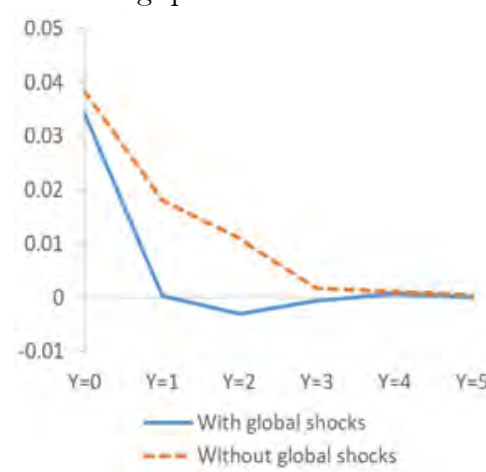

Response of output to fiscal shock

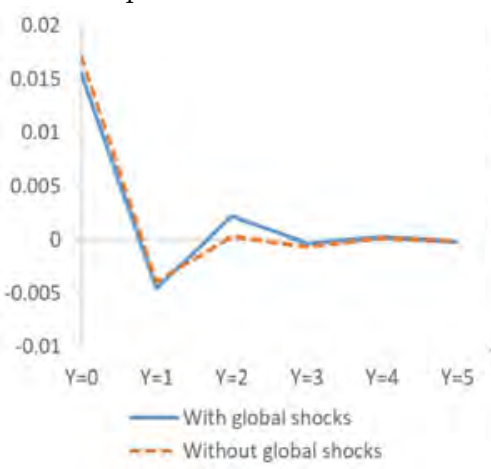

Response of debt-to-gdp to technology shock 0.02

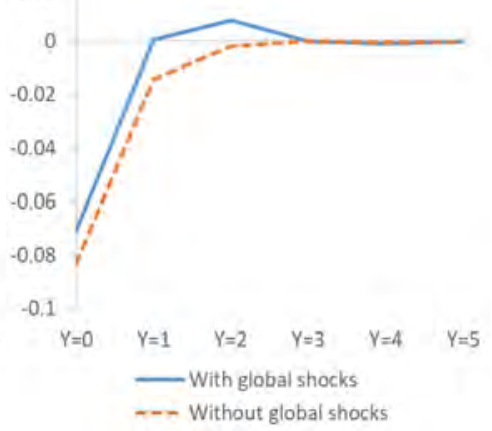

Response of output to technology shock

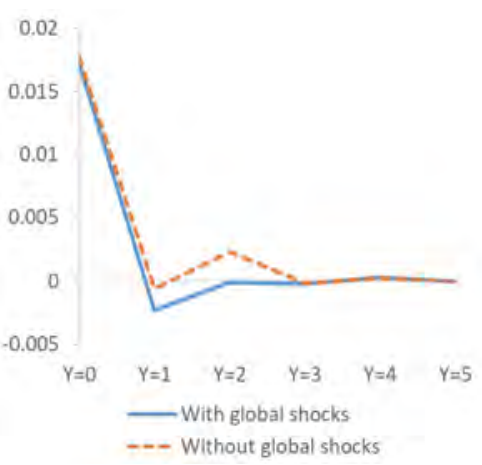


Figure S75: IRFs for Turkey in models with and without global shocks (median of posterior distribution)

Response of debt-to-gdp to fiscal shock

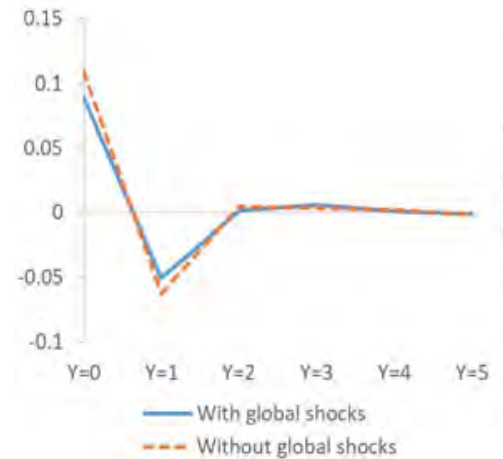

Response of debt-to-gdp to technology shock

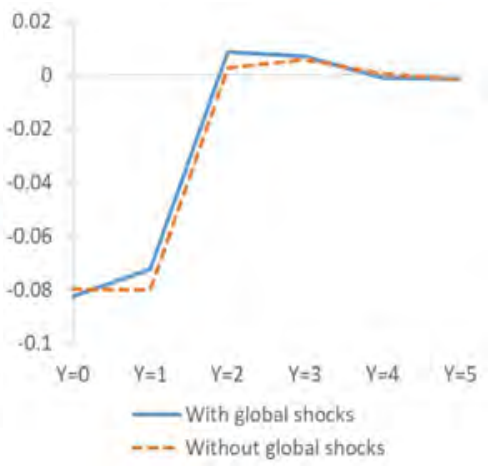

Response of output to fiscal shock

--- Without global shocks

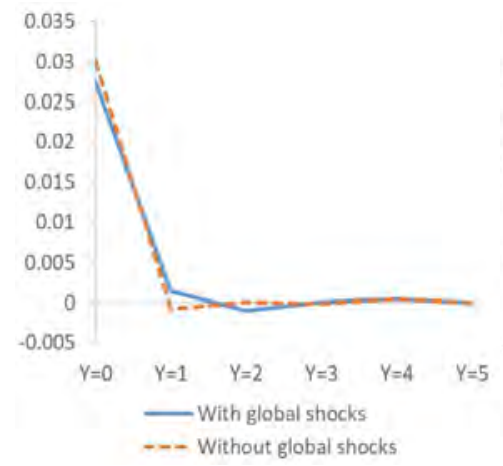

Response of output to technology shock

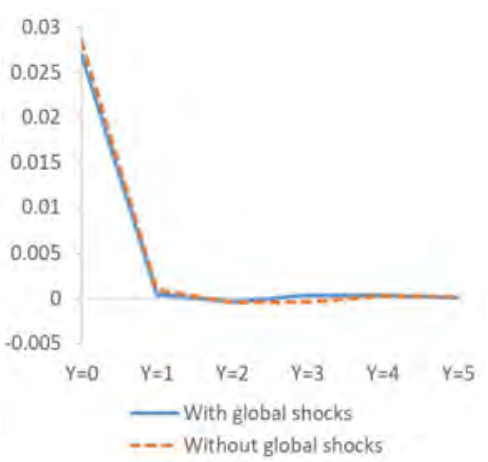

Figure S76: IRFs for UK in models with and without global shocks (median of posterior distribution)

Response of debt-to-gdp to fiscal shock

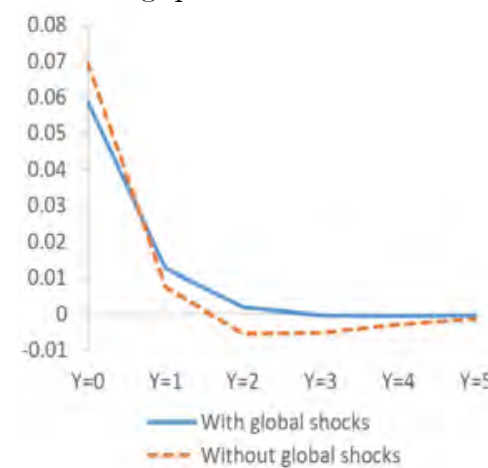

Response of debt-to-gdp to technology shock

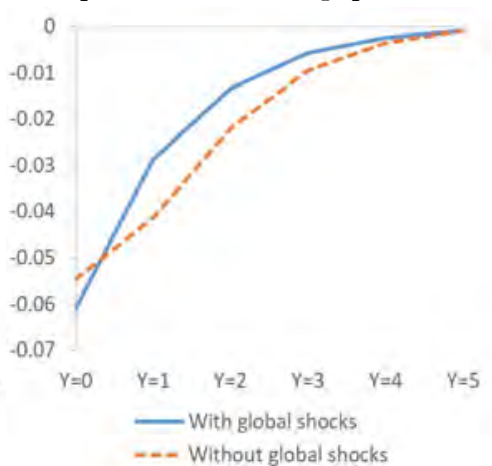

Response of output to fiscal shock

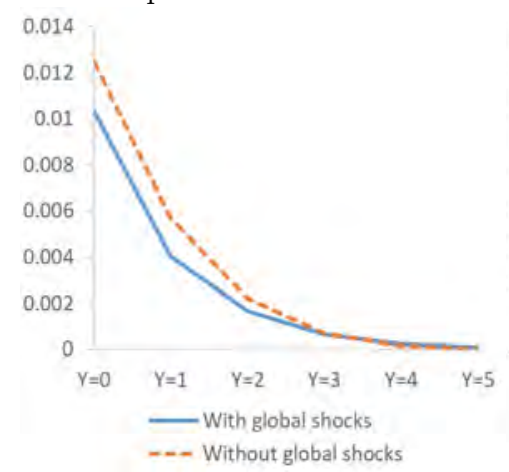

Response of output to technology shock

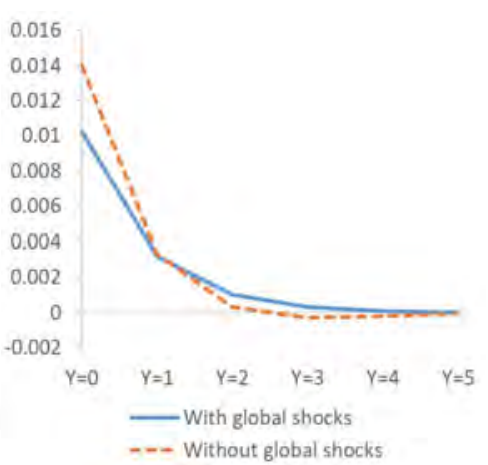


Figure S77: IRFs for USA in models with and without global shocks (median of posterior distribution)

Response of debt-to-gdp to fiscal shock

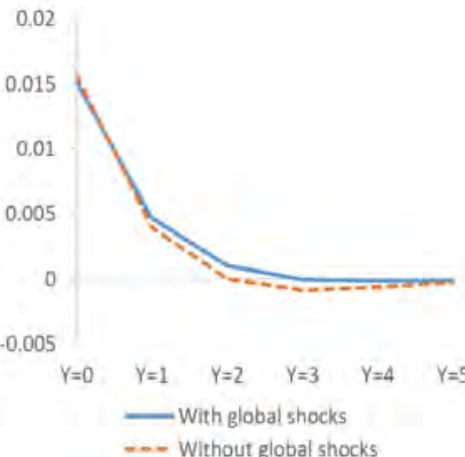

Response of output to fiscal shock 0.012

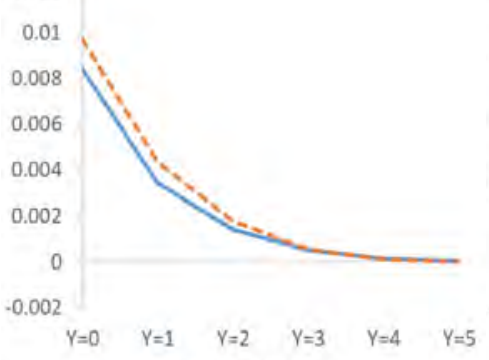

With global shocks -.- Without global shocks
Response of debt-to-gdp to technology shock

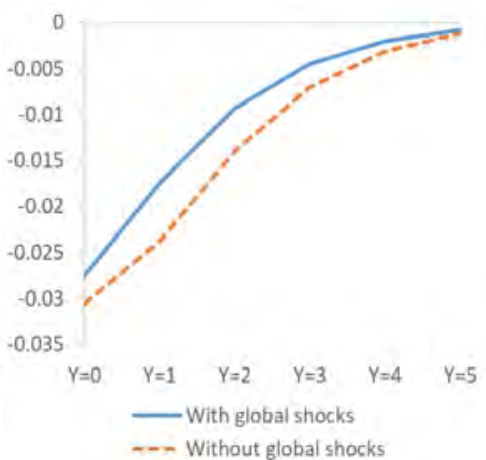

Response of output to technology shock

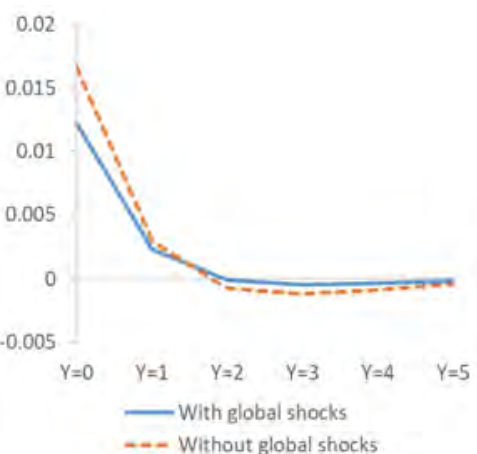

Figure S78: IRFs for Venezuela in models with and without global shocks (median of posterior distribution)

Response of debt-to-gdp to fiscal shock

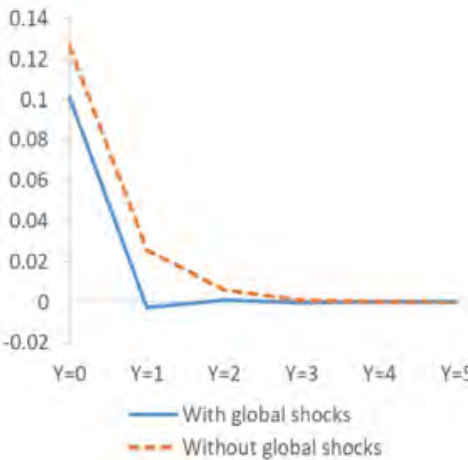

Response of output to fiscal shock

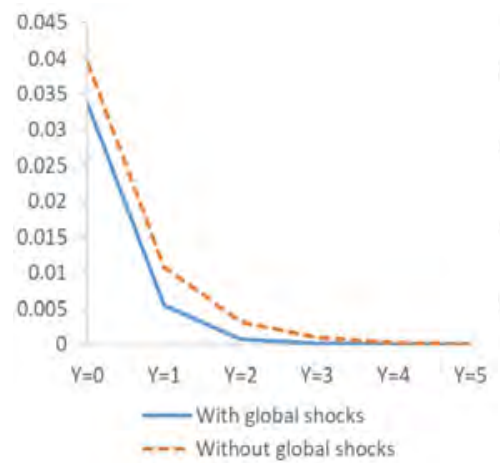

Response of debt-to-gdp to technology shock

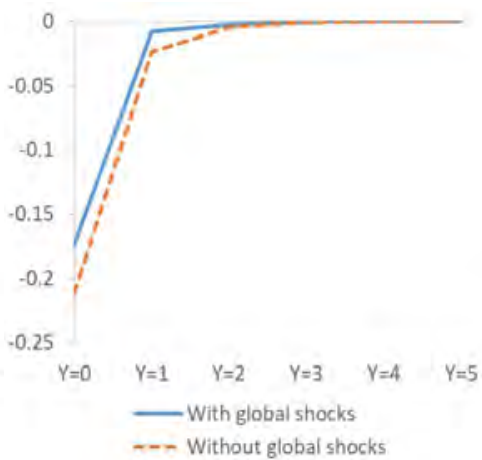

Response of output to technology shock

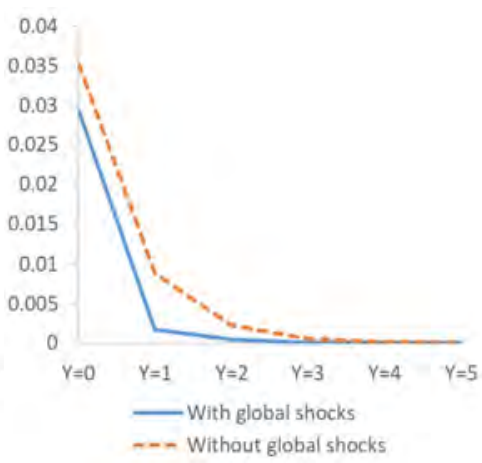

